GASPAR FERNÁNDEZ Y ÁVILA

\title{
LA INFANCIA DE JESU-CHRISTO
}



L

1] La Fncarnación del Hijo de Dios.

Coloquio Primero.

Personas.

La Virgen.

San Josef.

San Gabriel.

Santa Isabél.

Isaac Rabadan.

Jacob Pastór.

Josef Pastor.

Rebeca Villana.

Musica.

Aparece la Virgen en su Retrete, hincada de rodillas, con un sitial delante, en el que estará un libro abierto, como que está leyendo, y quando canta la Música, repiten entre muchos cada verso en tono de clamor, significando las voces de los Santos' Padres.

Mus. „l Oh Sabiduría Eterna

"que saliste de Dios vivo,

nvén á ensetiarnos piadosa

"de la prudencia el caminol

Mar. jOh Sabiduría Eterna,

engendrada en el Divino,

claro y puro entendimiento

de vuestro Padre infinito,

que con vuestro inmenso Sér

20

dais el ser á lo finito,

conservais todas las cosas,

y las disponeis Benigno,

Suave, P'o, y Clemente;

venid, oh dulce Amor míol

10

venid á enseñarnos ya

de la Prudencia el camino.

2] Mus. ${ }_{n} \mathrm{O}$ Adonay, Capitán

"de Israel, que á su Caudillo

"Moysés le diste tu Ley:

„vén, Señor, á redimirnos.

Mar. O Adonay, Capitán 
del Israel escogido,

que en la Zarza incombustible

aparecisteis Divino

á vuestro siervo Moysés:

tambien le disteis propicio

en la eminencia del Sina

los renglones peregrinos

de vuestra Ley Sacrosanta:

Vinid con brazo extendido

á redimirnos \&́ todos

10

por el pecado cautivos.

Mus. ${ }_{n}$ O Raiz de Iesé pura,

"de los Pueblos claro Signo!

$n$ no te tardes: vén, Clemente,

Mar. O̊ Raiz de Iesé pura,

"á librarnos de los vicios.

Signo el mas esclarecido

de los Pueblos, que os desean,

de los Reyes, que abatidos

á vuestros Piés rendirán,

su poder y su dominio,

á quien las gentes clamando,

como á su único asilo

pedirán misericordia;

no os tardeis: venid ya P'o

á librarnos Generoso

de nuestro fiero enemigo.

Mus. ${ }^{\mathrm{O}}$ Lucidísimo Orientel

Espejo el mas cristalino,

en quién se mira Dios Padre,

y os engendra como á su Hijo,

Esplendor de Luz eterna,

Sol de Justicia encendido

en el fuego del amor,

mas acendrado, y mas fino:

venid, guiadnos, que estamos

en tinieblas sumergidos.

Mus. ${ }_{n} \mathrm{O}$ Rey de las gentes todas, ndeseado, y aplaudido,

"Piedra angular: vén $y$ salva

nal hombre, tu hechura, é hijo.

Mar. O Rey de las gentes todas,

deseado, $y$ aplaudido,

Piedra angular misteriosa;

que con enlace Divino

uníis en vuestro Amor

lo distante y esparcido:

venid, $y$ salvad por Vos 
al hombre que por Vos mismo

fué formado de la tierra,

y unidle á Vos, Dueño mío.

Mus. "O Emanuel, Rey Poderoso,

ndeseo del Gentilisimo,

"nuestro fiel Legislador:

"vén, y sálvanos Benigno,

Mar. ${ }_{n}$ Acérquese, Gran Señor, acérquese, Dueño mío,

el día de tanta luz

10

para el mundo sumergido

en las sombras de la culpa;

Cúmplase vuestra Palabra, descended del alto Olimpo,

para hacernos venturosos,

ya que somos vuestros hijos."

Oh qué bienaventurados, qué dichosos, qué benditos serán los ojos que vean, y gozen tal beneficio!

y sobre todo, \qué gloria, qué honor tan esclarecido será para aquella Virgen, asombro, pasmo y prodigio

del Orbe, que ha de ser Madre

de mi Dios! segun lo dixo

en el capítalo siete

de su Sacro Vaticinio

el gran Profeta Isaías;

jojalá que á su servicio

la Divina Providencia

destinára mi alvedrío!

oh quien fuera esclava suyal ; oh quien

á esta Madre, y á este Hijo

viese en el mundol postrada

con respeto el mas sumiso,

besaria sus pisadas.

Oh, Dios Santo, oh, Dios Benigno!

quién será esta gran Doncella?

quién este inmenso prodigio?

quién tal Señora, $y$ tal Madre?

quién será, Cielos benditos,

Virgen tan feliz?...

Mus. María.

Sale San Gabriel de pronto, é hinca la rodilla.

Gab. Dios te salve, gran Princesa, llena de Gracia Divina: 
el Señor esté contigo, y por tanto eres Bendita entre todas las mugeres.

\section{La Virgen turbada.}

Mar. ¡Qué estupenda maravilla es ésta, piadosos Cielos! turbada estoy, y oprimida de dudas, y confusiones. Qué palabras tan divinas son éstas? y á mi que soy la muger mas abatida que hay en la tierra? Señor, Dios de la Sabiduría, descubridme este Misterio, porque estoy sorprehendida de gran temor y...

Gab. No temas,

Sagrada Virgen María, porque has hallado con Dios tanta gracia tan cumplida, que concebirás un Hijo en tus entrañas benditas y despues darás á luz, está tambien advertida que el Nombre que has de llamarle es Jesús, en quien se cifra la salvación de los hombres: será Grande en maravillas, llamarse ha Hijo excelso del Altísimo, y la Silla de su Padre, el Rey David le dará el Señor tan fixa, que reynará eternamente en la casa esclarecida de Jacob, noble ascendiente de tu Prosapia lucida.

Mar. ¿Cómo se ha de efectuar esta Sacra maravilla, pues tengo á Dios desde niña hecho voto de guardar castidad toda mi vida?

Vendrá el Espíritu Santo con su Presencia Divina á tí desde su Real Trono, y la Virtud infinita del Altísimo hará sombra á esta Obra peregrina; 
y asi el Santo que naciere

de tu Vientre, $\delta$ gran María,

llamaráse Hijo de Dios.

Tambien pongo en tu noticia,

como tu prima Isabél,

Esposa de Zacarías, conocida por la Estéril, concibió para su dicha un Hijo, sin que impida su anciana edad, porque Dios

10 quanto quiere facilita; y asi no le es imposible obrar tales maravillas.

Mar. Aquí está la humilde esclava

del Señor, que sacrifica

á la Suprema Excelencia

de su Voluntad Divina

la suya, muy diligente

á obedecerle rendida.

Hágase en mí tal portento,

20

cúmplase tal maravilla

según tu palabra.

Tocan instrumentos, y baxa en una nube una Paloma blanca, stgnificando al Espiritu Santo, y se pone cerca sobre la cabeza de la Virgen, que la tendrá inclinada con humildad sobre el sitial.

Gab. El Cielo

á la Casa de María, mi Reyna se ha trasladado. Cantad, nobles Gerarquías, celebrando la Bondad de un Dios que tanto se humilla

á favor de los mortales,

Entonad con melodía cánticos en alabanza de la humildad de María.

Mus. La Bondad de nuestro Dios,

y la humildad de María, dan nueva alegría al Cielo, y a la Tierra nueva vida.

6] Tocan instrumentos, se retira la Paloma, y la Virgen levanta 40 la inclinación.

Gab. A Dios, Purísima Madre del Verbo,..Sacra María, á Dios, Santisima Virgen, del mismo Dios escogida, .á Dios, Divina Senora, 
del Cielo, y Tierra alegría:

hijos de Adán, celebradla, alabadla, $y$ benedecidla. Vase.

Mus. Bienaventurado el Vientre purísimo de María, que contiene al Redentor, quien nos dará inmortal vida.

Mar. Válgame el Cielo! yo Madre de mi Dios? ó qué gran dicha! siendo yo una humilde esclava, tan alta Soberanía! Yo Madre vuestra, Señor? tantas honras á María? siendo una vil criatura, la Muger mas abatida que hay en el Mundo? quisiera en retorno de mi dicha daros las debidas gracias por mercedes tan cumplidas como Vos, mi dulce Dueño, me habeis hecho, siendo indigna.

Abrasados Serafines, llamas de amor encendidas, alabad por mí al Señor, que con entrañas tan pías miró á esta su humilde Sierva.

Hijos de Adán, que en continuas ansias deseais el ver aquel feliz, y gran día

de vuestro rescate, ya

se acercó vuestra alegría, ya teneis Humano á Dios. ya ha venido el gran Mesias, ya se han cumplido á la letra las Sagradas Profecías. No ceseis de bendecir

las piedades infinitas de este buen Dios Humanado. $\mathrm{Y}$ vosotros, fieles Hijas, de la gran Jerusalén, celebrad todas mi dicha, pues es para gloria vuestra, esta unión tan peregrina de nuestro Dios con el hombre.

Sale San Josef, y se ledanta la Virgen.

S. Jos. Esposa, y Señora mia?

Mar. Amado Josef, qué mandas? 
8. Jos. Obedecerte es mi dicha:

qué hermosura tan modesta!

no sé qué impulso me anima

de venir á visitaros,

y estando yá en vuestra vista,

no sé qué júbilo. nuevo,

qué superior alegría

siente mi alma de veros.

En que os ocupais, Señora?

qué haceis, amada María?

10

Mar. Señor, contemplando estaba

las piedades infinitas,

que á nuestro Dios de Israél

debe la inconstante, tibia,

y fragil naturaleza.

S. Jos. Esa es siempre tu continua ocupación, y exercicio:

en esta misma debían

emplearse las personas

todo el tiempo de su vida,

20

que entonces así ocupados

no ofenderían á su Dios,

que los conserva y los cría

para su amor, y servicio.

Mar. Ensalzado sea el Señor

por su Clemencia infinita.

S. Jos. Pues, Señora, á Dios sirvamos

lo restante de la_vida,

y no cese nuestro anelo

en cada instante del día

de alabarle, agradeciendo

piedades tan repetidas.

$\mathrm{Y}$ ahora, si dais permiso,

Esposa, y Señora mia,

me retiro á descansar

por aliviar las fatigas,

que á un pobre oficial le causan

las tareas que le obligan.

Mar. Pues antes quiero deciros

como he tenido noticia,

que á mi Parienta Isabel,

Esposa de Zacarias,

le ha concedido el Señor,

que aún siendo anciana conciba,

y quisiera me permitas

el que vaya á visitarla, que son deudas de la sangre, y el pagarlas nos precisa. 
S. Jos, Vuesta voluntad, Señora,

es tan unida con la mía, que quanto Vos dispusiereis

lo acepto, y tengo á gran dicha

obedeceros en todo.

Ordenad vuestra partida, quando os agrade, que yo iré en vuestra compañía.

Mar. Pues siendo de vuestro agrado, en amaneciendo el dia,

á vuestro arbitrio podeis, disponed nuestra partida.

S. Jos. Se hará como lo previenes:
A Dios, amada María.

Mar. A Dios, amado Josef.

Los 2. El Cielo guarde tu vida. Van.

Mus. "Lluevan las nubes al Justo,

y Mesias prometido

„produzca la tierra fertil

nuestro Salvador Divino.

Repitese cada verso como los de la $O$ : entre muchos, significando las voces de los Santos Padres, y sale Sin Gabriel.

Gab. Patriarcas, Profetas, Almas Santas, que en el Limbo esperais con ansias tantas Aquel día felize, $y$ venturoso,

En que á Dios humanado, que os liberte

De esa cárcel obscura de la muerte:

Suspended vuestras quexas, y clamores;

No os negueis al contento, aún entre horrores.

Mus. Convertid el llanto en gozo:

Acábense los gemidos,

Santos Padres, que ya Dios

Vuestros lamentos ha oído.

9] Gab. Y vosotros, mortales, que en lamentos,

No cesais de explicar los sentimientos,

Que os causa contemplaros_en estado

Tan mísero, infeliz, y desdichado,

Cesen, pues, de una vez las aflicciones,

De alegría ocupad los corazones;

Por que ya el sumo Dios de las venganzas, 40

Convirtió sus furores en bonanzas:

El León fuerte de Judá terrible,

Yá es Cordero mansísimo apacible;

El rectísimo Juez castigador,

Ya le teneis humano Redentor;

Pues inclinando su piedad afable determina

Redimiros benigno, y generoso: 
Escuchad ahora el modo prodigioso. Vánse. I

Mus. En el vientre de.María,

el Verbo Eterno Dios Hijo,

la humanidad ha tomado, y á su Persona la ha unido, por rescatar á los hombres del pecado primitivo.

Amante, piadoso, $y$ franco, hace este inmenso prodigio.

Salen Josef de Pastor, y Rebeca de Villana, hermanos, como 10 que van de camino.

Jos. Este camino es mijor

que el que vá por el barbecho.

Reb. Que le jace, si es mas largo,

que una soga: descansémos

por que estoi de tal aquel,

que no tengo ya en mi cuelpo

bueso que me quiera bien.

Jos. Tambien estó yo lo mesmo, que si huviera de quejarme, no me queara zagüero.

Reb. Qué lastima de Zagal!

qué delicao se ha jecho:

dempues que toa su via

10] anda tras de los Cameros por esos montes, y breñas, y ahora le duelen los huesos! no hay por aí quien lo llore?

Jos. Qué salailla te has jecho: no hay quien le ria la gracia?

Reb. Siéntate, y descansaremos.

Jos. Mas vale que nó, Zagala; por que en subiendo el repecho aquel de la man izquierda, mos encajamos de un buelo en la Montaña, $y$ allí alantillo trás un cerro está la majáa: Rebeca, no te sientes: vén sin mieo: ajila trás $\mathrm{mi}$, que ya

Reb. No quiero, mos quea poco.

por que yá estó mu cansáa, y dar un paso no pueo, sigun me duelen las patas.

Jos. Qué ganao tan pelvelso sois toitas las mugeres. 
Reb. Oyes, Jusepe: parejos.

Jos. Si en dando en una manía sois toas de tal perjeño, que no es pusible apearos de ella ni un Angel del Cielo, $y$ ansina el aconsejaros, es pedricar en disierto. Es como el otro que ixo, (y aquí viene mui á pelo) A la muger, y á la cabra 10 soga larga.

Reb. A ver qué lleno está el Zagal de razones!

Jos. $\mathrm{Y}$ toas con jundamento.

Reb. Qué si quieres.

Jos. Pues, jaz tú lo que te viniere á pelo, que yo no quiero quistiones.

Reb. Me truxiste, para eso? al instante te amontonas, $y$ te jaces un veneno: yo reniego de los hombres, bolaos toos.

Jos. Parejos.

Reb. Pus, Jusepe, yo no paso de aquí, y ansina me siento.

\section{Siénlase.}

Jos. en eso havía de venir, á rematar nuestro cuento:

á la muger, $y$ al cavallo, no hay que apretallo: me siento, mas que nunca á la Montaña, ni a la majáa lleguemos.

\section{Siéntase.}

Reb. Que sabijondo que estás?

Jos. Tambien se sabe entre cerros lo que enseña la experensia al Laino allá en los Puebros.

Reb. Dexate yá de andulemas, que estó jasta los cabellos, y dime cómo te vá de Zagal con tu amo nuevo?

Jos. En quanto al comijo, bien: se engullen bravos torresnos, guapas migas, lindo vino; el trato, Rebeca, es gueno, 
por que el Amo es el ricacho.

de estas montañas: yo creo,

que tiene de prencipal

mas de milenta carneros,

ovejas, es un sin fin,

ganao bacuno, un quento,

cabras, machos, $y$ pollinos

un andelubio, su apero

no lo tiene el mas llocio

de los gordillos del Puebro.

10

Las Viñas, y los Cortijos,

no hay que dicir, un protento.

Estoy pardiobre á apostar

$\operatorname{con}$ qualquiera, que en efleuto

sende Dan á Bersabé,

no hay mayorazgo tan gueno,

quanto pescas con la vista, y más, es too del viejo.

Si quiere Dios que mi Ama

tenga un hermoso varón,

será tan celebrao, que pienso

20

no habrá en toos los Nacíos

otro mayor nacimiento.

A lo menos la montaña

se llenará de contento,

$y$ por estos andurriales

arrebozará el festejo.

Reb. Estás soñando, Jusepe ?

Jos. No me vés que estó dispierto?

Reb. Calla, Jusepe, qui pienso te bulras.

Jos. De aqui á tres meses verás, como yo no miento.

Reb. Si además de ser anciana, es estíl?

Jos. Qué le jaremos? El viejo sende estonces está múo, yo no sé si es de contento de ver su moger preñaa, ú de otra cosa; en efleuto, él no jabra una palabra, aunque lo maten, y pienso que tambien tiene sordera, pus annque le jabren recio, no se dá por entendío.

Reb. Eso encierra algún Misterio.

Jos. Mas que encierre un Toro bravo

de siete años y medio,

lo que sé dicirte, es, 
que no jabra, ni aún de queo.

Reb. Pues no ha mucho que lo ví en una jiesta del Tempro, y quando salió, jabraba como una urraca; $y$ me acueldo, ví á Isabél; pero no reparé en eso.

$Y$ en efleuto, cómo ha sido esa trageria de ponerse múo el Viejo?

Jos. Ya sabes, que Zacarías 10 mi Amo, es uno de aquellos veinte $y$ quatro Sacerdotes, que asisten al Sacro Tempro. Estando junto en el Atrio del Tempro ya too el Puebro jué á jacer el Sacrificio, y á poner sobre el brasero aquello que guele muncho quando jumea.

Reb. El incensio.

Jos. Estuvo un valiente rato metío solo allá entro, y la gente acá esperando en el Atrio, discorriendo, qual sería la tardancia. Al cabo salió contento, como una Pasqua el sembrante, pero sin jabrar, jaciendo con los jojos mil visajes: yá se encaraba en el Cielo, yá alevantaba los brazos, yá los cruzaba: Al ver esto, dician toos confusos: Aquí se encierra Misterio, pus Zacarlas no jabra, ni oye, aunque le jabremos. Qué será? qué no será? y en esta dúa estovieron aquel día, y aún están, pus naa se ha descubierto, porque el amo está tan múo como al prencipio: en efleuto, ansina que arremató su semana allá en el Tempro, endilgóse á la montaña con su Moger, y tenemos, que al cabo de cinco meses, los que le estamos sirviendo 
reparamos con coriao

I

Reb. Sonichel -

que toito salió cierto.

que oygo unos isturmentos.

Suenan dentro instrumentos pastoriles $y$ cantan los demás

Pastores las siguientes coplas; los das se quedan suspensos durante la Muisica, y en acabando se levantan con regocijo.

Mus. Sea bien venía,

Nazarena hermosa;

sea bien llegaa,

la fragante Rosa.

10

Reb. Jusepe, sino me engaño,

esta ha de ser una jiesta,

date priesa, baylarémos.

Jos. Más que agora estás ligera,

y no te duelen las patas;

en oyendo las mozuelas

tocar algún isturmento,

no hay quien sujetallas puea.

Mus. Sea bien venía,

20

Nazarena hermosa:

sea bien llegaa

la fragante Rosa.

Al acabar esta Copla, que se cantard dentro, salen de camino $S$. Josef, y la Virgen, delante Jacob, Josef, y Rebeca baylando, tocando, y cantando la siguiente Copla, y dando vuelta, se entran por otra puerta.

Mus. Venga en hora guena

la bella María,

á dar á estos montes

pracer, y alegría.

Salen Santa Isabel, \& Isaac Pastor como acelerado.

Isab. Qué hay de nuevo, Mayoral?

en gran cuidado estoy puesta

viendo tu aceleración.

Isac. Pues, Muesama, no lo tengas,

que no es pesar quien me mueve,

á veros con tanta priesa:

reguzijo sí, pracer,

y alegría que os espera

$y$ toos por celebrar

á una hermosa Nazarena,

que con su Esposo ha llegao

á la montaña: es tan bella,

que no hay Cielo, Sol, ni Luna,

Llucero, ni crara Estrella 
14

con quién comparalla, qué!

es muncho más su belleza:

parece rosa temprana

de Jeric $\delta$, y azucena,

clavel, jazmín, tulipán,

nardo oloroso, diamela,

aljaili, $y$ aquesto es naa,

porque más jermosa es ella,

María, vuestra Prima, es

la que mi llengua celebra,

10

que aunque iga en su alabanza,

muncho más corta se quea:

viene con José su Esposo,

que ha sabío allá en su tierra,

estás preñaa, y por ser

ambas de una sangre mesma,

ha querio vesitaros.

Suena dentro Música Pastoril.

Mas tened, que ya resuenan

los isturmentos, y ansina

es seffal de que ya llegan:

voyme volando, Muesama. Váse.

Isab. Venga muy en hora buena

á esta su casa mi Prima

á colmar con su presencia

el júbilo, y el contento,

que en ella se manifiesta.

El Señor con varios modos

su felicidad aumenta:

quisiera en esta ocasión,

que mi Esposo no estuviera

mudo; porque celebrára

como es debido, y sirviera

á huésped $\tan$ estimada;

pero Dios así lo ordena,

hágase su voluntad,

como en el Cielo, en la tierra.

Voy á anticiparme el gozo

recibiendola, que es fuerza

no tarde, pues se han oydo

las voces que la celebran. Vase.

14] Cantan los pastores la siguiente Copla, y al segundo verso salen por otra puerta San Josef, y la Virgen como antes, los Pastores y el Rabadan, y quedan los Santos enmedio.

Mus. Venga en hora guena la bella Marfa, 
á dar á Muesamos

pracer, y alegría

Jos. Ha, Rebeca, qué contento!

menéa esas castañetas,

que hoy se junde la montaña. 5

Reb. Más que se junda.

Jos. Pus echa

un fandanguito, que quiero

festejar mi Nazarena.

Isac. Pus vaya, Zagales, vaya.

10

Baylan los dos.

Jos. Jáste peazos, Rebeca,

con garbito, y con salero.

Al acabar el bayle.

Viva María mi Reyna.

Isac. Basta, Zagales, que yá

sino me engañan las señas,

Muesama viene: apartaos,

dejad franca la verea.

Se apartan a los lados, y sale Sta. Isabel y se pone á la 20 izquierda de la Virgen.

Mar. Dios te salve, amada Prima:

el Señor contigo sea,

recibe mi voluntad,

Abrázanse.

que sumamente se alegra

de verte, $y$ te felicita á un tiempo.

Isab. El mismo Señur te premie,

Prima mía, amada prenda,

el haber venido á darme

este consuelo, quisiera

fuese mi agradacimiento

comparado á tu fineza.

Muy en horabuena vén

a hacer feliz, y suprema

mi dicha, gracias á Dios,

que asi Piadoso lo ordena.

Mirando a San Josef.

Primo Josef, Dios te salve:

eres dichoso en la tierra,

pues el Cielo te escogió

con la prodigiosa seña,

de que esa vara en tus manos, 
siendo seca, floreciera,

para que fueses Esposo

de mi Prima, el Señor quiera

gozes dilatados años

de companfía tan buena:

de gracias $y$ beneficios

te colme su Providencia,

y prepare Generoso

á felicidad inmensa.

Seas bien venido, Primo,

10

á hacer mi dicha completa,

á dar honor á esta casa,

dispón como Dueño en ella

lo que fuese de tu agrado.

S. Jos. Prima, y Seflora, quisiera

saberte corresponder

agradecido á fineza

tan excesiva, muy propia

de tu gran benevolencia:

el honor es para mi,

20

la dicha la experimentan

15

mis ojos de haberte visto; benditas

15] las Divinas Providencias

de nuestro Dios de Israëll

muy rendido á tu obediencia

me tendrås humilde esclavo.

Isac. Muesama, sea en horaguena,

me alegro tengas el gusto

de ver á tu Parentela.

Jos. Yo tambien igo lo mesmo, por no andar con andulemas.

Reb. Yo, Señor, por no errar, te doy mil en horaguenas.

Jos. Y tú, Jacob?

Jac. Yo, Muesama, lo que igo es, que quixera

no estuviese el Amo múo en esta ocasión, $y$ juera entonces doblao el gusto.

Isab. Lo que viene de la excelsa Divina Mano, debemos aceptarlo por fineza.

Jos. Dice Muesama muy bien:

Antańazo se me acuelda

que un día majando el ajo para jacer cachorreffas, me entrecogí el deo gordo, que no me supo á camuesas, 
y me ixo el Rabaan:

Esa, Jusepe, es fineza

de la Mano del Señor:

yo le ixe: esa te muerda,.

que no quiero estos regalos,

aunque de la Groria vengan,

y no es la Mano de Dios,

le respondi, ni lo sueña,

quien me ha machacao el deo,

que si bien se consiera,

10

jué la mano del mortero.

Esa bola acá no entra.

Orra vez un coscorrón

me pegué contra una puerta,

que con tal calamoschaso

me partí media cabeza;

al recebir este triunfo

me ixo entonces Rebeca...

Isac. Calla, bárbaro, no sueltes

gaspachaas, ni simplezas;

no sabes lo que te ices.

Jos. Ojalá no lo supiera,

y lo hubieras tú sabio.

Isac. Si ese cuento aquí no pega, ni al canso viene.

Jos. Por eso

lo traygo yo, y si viniera, no era menester traello.

Isac. Muesama, con tu licencia mos vamos a la majaa, y otra vez la enhoraguena te damos de tanto gozo.

Jos. A Dios, bella Nazarena.

$$
\text { A San Josef. }
$$

Tocayo, jasta otra vez,

Oís, Zagales?

Todos tres Qué intentas?

Jos. Mos hemos de despeir llorando? siga la jiesta: tocar esos isturmentos.

Tocan, y baylan dando una vuelia, y se retiran, quedando solos los Santos.

S. Jos. Y yo, si me das licencia, voy á ver á Zacarias, que el afecto lo desea. Váse.

Mar. Prima, y carísima mia, 
Dios te salve, $y$ te conceda su Luz Divina, y su Gracia.

\section{Isabel se arrodilla ante la Virgen.}

Isab. Feliz, Señora, en la tierra debo llamarme, á tus plantas

postrada está mi baxeza;

pues el Cielo generoso

conmigo, me manifiesta

el Misterio mas profundo,

que hoy en tu Vientre venera

10

mi respeto el más sumiso:

dexa que bese la tierra

que pisas, amada Prima,

dichosísima Doncella.

Hace demosiracion de humilarse a besarla los pies, y la Virgen la detiene levantándola.

Mar. Levanta, querida Prima,

Isab. Pronto estoy á tu obediencia.

Abrazanse.

Prima, que de Israël la Gloria eres:

Bendita tú entre todas las mugeres,

$Y$ bendito es el Fruto Generoso

De tu Vientre Sagrado Venturoso.

De donde a mí, carisima María,

De donde a mí honor tanto? qué alegrial

Que venga a visitarme cuidadosa,

De mi Señor la Madre Prodigiosa,

Siendo su humilde sierva, $\delta$ gran Señora!

Luego que de tu voz consoladora

A mi oído llegó (qué gran ventura!)

Esta Salutación (con qué dulzura!)

De alegria y contento se elevó

hacia á ti mi pensamiento!.

O Bienaventurada! que has creido;

Por tanto se ha de ver en tí cumplido

Con toda perfección lo que el Senor

Te ha dicho por su fiel Embajador.

Vuelve, Señora, á mis brazos, porque á ser felices vuelvan.

Abrdzanse.

Tus palabras misteriosas

me han dado la inteligencia

de Soberanos Arcanos,

maravillas estupendas, 
de nuestro Dios de Israèl.

Bendita sea su Clemencia, que se ha dignado atender

á esta pobre humilde sierva.

Lo que resta, amada Prima,

es, que tu amor me conceda,

estés en mi compañía,

para que se cumpla en mí

lo que Dios Piadoso ordena

Mar. Desde Nazaret, Señora,

he venido á tu obediencia;

mándame lo que te agrade.

10

Isab. Qué humildad, y qué modestia!

vamos, y descansarás,

Señora, de la molestia

del camino.

Mer. $\quad S i$ te place,

primero con tu permiso

visitaré á Zacarias.

Isab. Vamos, Prima, enhorabuena. Váse.

Finis. 
La Expectación de Maria Santisima.

\section{Coloquio Segundo.}

Personas.

La Virgen.

Sen Josef.

San Gabriel.

Herodes Rey.

Un Ministro.
Isaac Rabadan.

Jacob Pastor.

Josef Pastor.

Rebeca Villana.

Acompanamiento.

Salen Isaac, Jacob y Rebeca.

10

Reb. Señor Rabaan, qué es esto?

en la Aldea, acompañao

de Jacob! cómo no viene

el probete de mi helmano?

Isac. Habrás de saber, Rebeca que sende la Montaña al Puebro, son menester $l$ ien contaos quatro días de camino, conforme lo había pensao, lo pensó tambien Jacobo, $y$ al punto determinamos despeirmos $y$ allá Jusepe tu helmano jué a Belén en el Borrico con la andustria de jerrallo; á más tardar vendrá boy, $y$ mosotros entre tanto jácia la Torre de Edér vamos á buscar un Amo.

Reb. Y quél no me cuentas naa del nino tan celebrao de Isabél?

Isac. Eso, Zagala, 
jué un pruigio muy colmao,

1

era menester estar

de espacio para quentallo.

Reb. Pus dímelo, Rabaan,

que tiempo tienes sobrao

para llegar en el dia

á la Torre.

Isac. Es, pus, el causo

que se allegó la hora

a Muesama de contao

10

y nació un jermoso muchacho,

mijor diré, que era un Angel

$\tan$ espercoido $y$ branco,

que á la leche le decía:

quítate allá;

de suerte, que aquella noche

jué un laberintio abreviao

la Montaña de Judea.

Jac. Jamás he visto en mis años

noche y dia de más groma.

Reb. Quien se oviera alli jallao!

20

Isac. Al istante los Parientes

$y$ too aquel vecindario

se endilgaron á la casa,

venían desatentaos

20]

con el regucijo, $y$ daban

el parabien a los Amos.

En estas cosas quearon, quando arrancamos mosotros, y otra cosa se ha queao.

María la Nazarena,

aquella que celebramos,

$21]$

quando juiste á la montaña

allá los días pasaos,

se ha mantenio tres meses

a Muesama acompañando.

Ansí que el Nino nacib,

la primera que en los brazos

lo tomb, jué esta Señora,

luego lo estuvo fajando.

Dempues a los nueve días

ya el Nifio circuncidao, jué su Esposo á la montaña,

y á Nazarén se la traxo.

Es quanto dicirte pueo;

y á Dios, porque ya mos vamos.

Reb. Antes que os mueis, quixera

me dixeses otro causo. 
Isac. Y qual es?

Reb. Si se ha sabío dempues que jabra ya el Amo qué le socedió en el Tempro quando enmueció.

Isac. Tu helmano, y este Jacobo lo saben.

Jac. Yo se lo oí á un Anciano, Pariente de Zacarias, quien se lo ixo: jué el causo que ansí que allegó al Altar, al tomar el incensario, vió á la derecha un Mancebo, ya Zagalón muy gallardo, tan lleno de clariaes, que Muesamo amedrantao no se atrevia á jablalle: como lo vió tan turbao, el guen Mancebo le ixo: porqué estás acobardao? no temas por verme aquí; que no vengo a hacerte daño, solo te vengo á dicir, que tu oración ha alcanzao el ser oía: Isabel, tu moger, aún sin embargo de ser anciana $y$ estil, te ha de dar á luz en llegando su debío tiempo, un jijo, á quien pondrás de contao por nombre Juan, y será tu gozo de gran tamafio en tan feliz Nacimiento: y munchos regucijaos se alegrarán ese día. Será grande y encumbrao ante el Señor,-y en su vía no lo verán destemplao; pus no ha de catar el vino ni la cidra; tambien ba de convertir á munchos extraviaos de los jijos ds Israel á su Dios y Soberano, ante el qual caminará con espíritu agraciao, y un valor como el de Elias, dando voces pedricando, 
para convertir á toos

los del viejo, al nuevo estao:

y a los que son caprichúos,

incréulos y atestaos,

los reucirá, de suerte

que los pondrá aparejaos

a recibir al Señor.

Estonces ixo Muesamo:

¿ cómo ha de ser eso ansí, quando soy un probe anciano,

10

y mi moger un cotral?

El Mancebo de contao

le ixo: Yo soy Grabiel,

que ante Dios estoy gozando

de aquella Suma Bondá,

y á hablarte soy t.mbiao

y a anunciarte estos Misterios;

$y$ por quanto te has mostrao

incréulo a mis palabras,

sende ahora jasta quando

20

se cumplan estos pruigios

te estarás ansí callao

$y$ no has de poer jabrar

aunque quieras: de contao

tomó lias y buen viento,

y se ausentó de un bolazo,

y el probe Viejo queó

como un Palacio encantao.

Reb. A ver, Jacob, cómo sabe!

parece que has estodiao?

Isac. Este es un pozo de cencia,

Teólogo de secano.

Jac. A lo menos mi memoria para embuchar es un pasmo.

Reb. Y sigún lo referío,

ese Niño será un Santo?

un gran Plofeta?

Jac. Que ices?

será esta Niño un Santaso,

y sigún las pintas trae

el mayor de toos quantos

han nacío de mogeres;

no es cosilla de coriao,

más que Plofeta ha de ser,

y si me antoja ...

Isac. Aspacio!

no te metas en jonduras,

que eso no es para los gansos, 
como musotros, que semos

probes patanes del campo;

vámonos luego a la Torre

de Edér, que es tarde.

Jac. Pus vamos.

Isac. A Dios, Rebeca.

Reb. Yo voy

\& esperar luego å mi helmano.

Vánse cada uno por su lado, y sale por otro Sr. S. Josef.

S. Jos. Altísimo Dios, Señor

10

en Sabiduría inmenso;

pues que á Vos nada se oculta,

bien conoceis mis desvelos,

con vuestra Divina luz

alumbrad mi entendimiento,

para no precipitarme

en un fiero desacierto:

Yo entregué mi voluntad

como en un seguro puerto

á la Esposa, que tu mano

ne franqueó allá en el Templo.

20

Nadie que la ha conocido

hasta hoy,

pudo poner, ni aún por suefio

duda alguna en su recalo,

y excelentes pensamientos.

Negar tambien lo que pienso

y aseguran los sentidos,

es imposible: yo muero

á fuerza de tanta pena:

aquí hay oculto Misterio

que yo no alcanzo, Seffor,

amparadme en tal aprieto.

Discursos, dejadme ya,

no me atormenteis, recelos,

imaginación, cesad,

que mi Esposa es un compendio

de peregrinas virtudes.

Ella es del Estirpe excelso

de David; sus Padres son

Joaquín y Ana, mis Deudos;

con que siendo ella mi sangre,

siendo tal su Nacimiento,

24]

su amor á Dios tan perfecto

¿había de ofenderme $a$ mi ?

Ea, la misma razón,

con claridad estoy viendo, 
que la disculpa, mas ya

los sentidos arguyendo

con pruebas muy convincentes

la condeuan, esto es cierto:

la experiencia lo acredita.

Valedme, piadosos Cielos!

Tres meses Maria ha estado en la Montafia, sospecho... ¿Yo sospechar de mi Esposa, siendo en pureza embeleso de la virtud misma? miente mi atrevido pensamiento, que ella es más pura que el Sol en su Celeste Emisferio;

su candor es sin igual, en ella no cabe yerro. ¡Qué haré, ó gran Dios de Abraham, de Isaac y Jacob inmenso!

qué haré, Señor? recibid ante vuestro acatamiento

mi espíritu, que afligido os pide alivio y consuelo.

\section{Reflexiona.}

Señor, el dexarla intento

\section{Como turbado.}

Voyme sin decirla nada.

¡Oh, qué compasión la tengo,

contemplándola tan pura,

pobre, sola y sin remedio!

¿s posible que María

me ofendib? yo no lo creo:

¿ una muger bien nacida, virtuosa, vivo exemplo

de peregrinas virtudes?

Ay Dios mio! suefio siento:

ó quien para no sentir ...

Siénlase, ponese la mano en la mexilla, y con los ojos cerralos como que está sontando, dice los versos siguientes:

tantas penas $y$ tormentos,

durmiera siempre, que al fin todo lo suspende el suex́o. 
Tocon instrumentos, baxa S. Gabriel y aplicandose al oido, I le dice lo siguiente:

Gab. Josef, hijo de David, no temas, dexa el recelo que aflige tu corazón: recibe con sumo afecto á tu Esposa fiel María, que lo que su vientre excelso contiene, por obra ha sido del Divino Paracleto; 10 por tanto á tu cuydadoso zelo queda ponerle por nombre Jesús; él mismo á su Pueblo salvará de sus pecados.

Así lo ha ordenado el Cielo, para que se vea cumplido tan soberano Mysterio.

Vise de pronto, y S. Josef dice entre suentos:

S. Jos. Aguarda,

Paraninfo, qué consuelo me has dado! qué? no prosigues? a donde estás, dulce Dueño? no te vayas; no me dexes: quanto me dices, te creo: verdad es, porque Maria en Santidad es portento; dexa que bese tus plantas por la merced que te delo.

\section{Despierta.}

Válgame Dios! qué prodigio!

Si de la muerte es el sueño imagen, ¿cómo la vida me dió? qué dulce embeleso! en las tinieblas la luz encontró mi entendimiento.

Oh, Esposa mía Divina, mejor diré, Sacro Templo donde está Dios Humanado! Oh María! ¡cómo puedo invocar tu dulce Nombre, habiendo tan indiscreto atrevídome a dudar tu fidelidad!

Voy, Señora, á arrojarme á tus piés, para que el yerro 
que cometi, lo perdones,

y me admitas por tu siervo.

Váse, $y$ salen Herodes $y$ un Ministro.

Her. ¿Ya habrás visto qué contiene ese edicto del Imperio?

Min. Yo le he visto, Gran Señor.

Her. Y a qué se dirige?

Min. Leo?

Her. No es necesario, decid, porque siempre he sido opuesto

á oir con expresión

10

órdenes de otro Supremo.

Harto me pesa este yugo,

que ganó el Romano Imperio

en Judea, Galilea

y Filistin; ; oh quién luego

pudiera eximirse de él,

para estar con más sosiego

independiente, absoluto

en mi Prefectura y Reynos!

en fin, en breves palabras

referidme su contexto.

Min. Manda, pues, ó Gran Señor ...

\section{Herodes ayrado.}

Her. Este estilo es indiscreto;

pues aunque sea Soberano

Cesar Augusto en mis Reynos,

estoy yo delante, $y$ sabes

que lo siento, y que me ofendo:

no vuelvas en mi presencia

á decir: manda el Imperio.

Min. Mi ignorancia perdonad.

Her. Adelante.

Min. Su contexto

se reduce á disponer

por un general Decreto

Cesar Augusto Octaviano

en todo su vasto Imperio

un Padrón ó Descripción

que ha de escribir cada Pueblo

40

en que se apunten los nombres

y sobrenombres de aquellos

que por oriundos conozca:

esto en suma es el Decreto.

Las penas con que lo impone,

las dexo ahora en silencio, 
por no molestaros más,

Her. Despacio está allá en su Imperio

Cesar Augusto Octaviano;

ipues así lo ordena el Cielo,

forzoso es sufrir, paciencia;

que en estando un Rey sujeto

á otro Supremo, es preciso

obedecer: estoy hecho

cargo del Edicto; id,

y con aparato regio

10

Min. Señor,

darlo al público,

voy al punto á obedeceros. Vase.

Her. Si se hallara hoy la Judea

como en los pasados tiempos,

co consintiera este yugo

$\tan$ penoso y tan estrecho:

la que antes se miraba

con temor y con respeto,

está ya hecha ilusión

20

de todos los extrangeros;

no fuera así, si viviesen

los valientes Macabeos

por sus hazañas ilustres;

ni sería, si á mi acero

acompañasen las fuerzas

de mis Vasallos Hebreos;

entonces yo libertara

mi Prefectura y mis Reynos

de la cadena que arrastran,

del yugo infame y grosero

que les abruma y oprime;

hiciera ver al Imperio

Romano, quién era Herodes

Ascalonita Iduméo.

Pero, en fin, asi conviene, suframos hasta que el Cielo por satisfecho se dé:

mejor es dexarlo al tiempo.

Váse, y salen Isaac, Jacob y Josef Pastores.

Jac. Lo cierto es, Rabaan. que es una gran conveniencia apacentar el ganao tan vecinos a la Aldea;

pus casi toos los dias, sin que se pase molestia, sabemos de la familia. 
Isac. Por fin esta es nuestra tierra; que, lo que Dios no permita, si mos duele la cabeza, en dos brincos que peguemos, mos zampamos en la Aldea; es como el otro que ixo:

A tu tierra, Grallo, apriesa, aunque sea con un pié.

Jos. Lo que siento en mi concencia, que en esta Torre de Edér no se engulle a boca llena, como en la Montaña, allí siempre estaba bien repleta la vicaría de torreznos, chicharrones de manteca, tortas de aceyte, guen vino, y si acaso alguna oveja enfermaba de floronco, toz, ciamotro, ó ruinera, al menute en la barriga, le dábamos con presteza entierro de capa, aquí unas malas cachorreñas, alguna vez los maymones, y rara vez una oveja, y. esa sarnosa; de suerte que hemos venio a esta tierra a purgar nuestros pecaos en continuas obstinencias.

Isac. Eso es quexarse de vicio.

Jos. Si repleto yo estoviera, de vicio me quexarfa, mas no estando, es de miseria, y si no, traslao a mis tripas, que toas son de reserva.

Isac. Pero mira, aquí gozamos la cercanía de la Aldea.

Jos. $\quad \mathrm{Y}$ allí gozaban mis tripas lo que aquí siempre desean.

Sobre too, Rabaan, dexémonos de quimeras, mi casa, mi Payre, y Mayre, mi Alcurnia toa, $y$ mi tierra es donde me dan guen trato, lo demás es friolera.

Isac. Pues guélvete á la Montaña.

Jos. Ojalá que me golviera.

Jac. El remedio está en la mano, 
Isac. Pus, Zagal, tener pacencia, que tras de este tiempo malo, vendrá otro mijor.

Jos. Si acierta, que quizá tras de este malo, vendrá otro peor: pluguiera, que este no hubiera venio.

Isac. ¿Qué sabes tú, si te espera de la Gloria algun consuelo?

Jos. Lo que agora yo quixiera, juera consolar las tripas.

Jac. Caa loco con su tema, no sales del P. A. N. Pan.

Jos. Como que en en el Pan se encierra too mi vivir.

Isac. El Cielo me permita que te vea jarto de una vez.

Jos. Si quieres, la ocasión del mundo es ésta.

Isac. Siempre estás tu bien dispuesto.

Jos. Antes con las obstinencias, estoy siempre mal dispuesto.

Isac. Dexarse ya de frioleras, vamos al causo: Josef, aparéjate la bestia,

Jos. A qué?

Isac. A que le echen una pieza al Caldero, que se sale.

Jos. Iré como una centella, si me dais de merendar.

Isac. Jaced unas cachorreñas: vamos al rancho.

Jos. Bendita

la boca que tal ordena. Vínse.

29] Aparece la Virgen en su retrete, arrodillada, $y$ antes de decir tocan instrumentos.

Mar. Dulcísimo bien de mi Alma,

Dueño, Señor y Dios mío,

Criador del Universo, a quien mirais tan benigno: i Quando besaré, bien mío, como sierva las pisadas de vuestros piés peregrinos,

y llegaré como Madre

a estrecharos. Hijo mio! 
¿ cómo hará oficio de Madre

con Vos, quien no ha merecido

ni sabe hacer él de esclava?

¿Y qué haré yo, bien de mi alma,

qué haré, dulce Dueño mío!

¿si solo venís

al mundo, con el destino

de padecer y morir,

si á este cruel Sacrificio

no os acompaño muriendo,

10

siendo Vos mi hijo?

Haced tenga yo, bien mío, parte en todos los trabajos, aflicciones y martyrios

de vuestra Vida, pues sois

mi Dios, mi Señor, mi hijo.

Sale San Josef, y levántase la Virgen.

S. Jos. Purisima Esposa mía, mi corazón oprimido

de sumo dolor, no acierta

de esta vez a prorrumpiros

la funesta novedad

que hoy en Nazareth se ba dicho.

Habeis de saber, Señora, como de Roma ha venido

de órden del Emperador

Cesar Augusto un Edicto, en que manda á todo el Orbe,

sin valer algun motivo

de escusa, ni otro pretexto,

se escriban en los registros

comunes de cada Pueblo

los nombres de sus oriundos:

y como toda mi casa

es de Belén, me es preciso,

obedeciendo el mandato,

partirme luego á cumplirlo.

iOh que pena tan atroz

aflige el corazón mio!

¡ cómo siento yo, Señora,

cómo siento que el Edicto

haya venido á este tiempo!

31] Mar. Esposo, no os afijais:

pues Dios en esto es servido,

conformémonos alegres

con sus Decretos Divinos;

su voluntad es nacer 
en pobreza y desabrigo,

$y$ por eso determina

en este tiempo ese Edicto.

Vamos pues, Esposo mio, vamos á Belén, que es Casa

de Pan, en donde mi Hijo

se ha de franquear al hombre,

por quien al mundo ha venido.

Yendo yo con vos, Josef,

no le temo á los peligros,

y mas llevando en mi vientre

al Verbo Eterno mi Hijo.

Asi, templad vuestro llanto,

que estos son de Dios juicios.

S. Jos. El consuelo que me resta,

es que en Belén tengo amigos,

y me harán la caridad

de darnos algun abrigo;

tambien tengo alli Parientes,

pobres unos $y$ otros ricos;

si ac aso algunos negasen, otros nos darán alivio.

Lo que nos resta, Señora,

Es saber quándo partimos

de Nazaret á Belén,

á cumplir con tal Edicto.

Mar. Quando quisiereis, Esposo, estoy muy pronta á seguiros.

S. Jos. Pues voy con vuestra licencia

y la de ese tierno Nifro

que humanado yo le adoro

y sagrado por Dios bendito,

á disponer el viage,

y luego al punto partimos.

Vánse, y salen Josef asustado, y Rebcca.

Reb. Jusepe, qué es lo que traes?

Jos. Que vengo lleno de mieo, sende arriba jasta abajo.

Reb. Desajógate, dí presto tu bien ó tu mal, por ver si aliviarte en algo pueo.

Jos. Escúchatne atentamente, porque el causo no es muy gueno.

Habrás de saber, Rebeca, que como iba iciendo, el Rabaan me mandó aparejase el jomento, 
y me endilgase a Belén

a remendar el caldero:

apenas lo aparejé,

quando subí como un trueno,

y en un vesible pillé

el camino, como suelo,

Ansina que yo y el burro

llegamos dambros al Puebro,

a Dios gracias con salú,

y mos comimos el pienso,

10

juimos al punto a llevar

a remendar el caldero:

quando yendo por la calle

el dianche del pollinejo,

enderezó las jorejas,

$y$ más ligero que un viento

empezó a repartir cozes,

y a tirar tan recios truenos,

que cata aquí, que en un triz

sin dalle cudiao de ello,

por las jorejas me echó

y me estrelló en aquel suelo.

Quando al menute, al istante

se juntó tanto mozuelo,

y en lugar de levantarnos

a mí y al burro del suelo, mos pegaron tantos gritos, con tal risa y tal estruendo, que espantaos yo y el burro, mos queamos patitiesos ;

no jué aquesto lo más malo, sino que unos zagalejos, asusaos de los grandes, como duendes acudieron, $y$ a pellizcos y porrazos mos levantaron del suelo.

Me puse tan collorao, $\tan$ amarillo y $\tan$ prieto con la vergüenza que tuve, que por poquito me muero. Estonces saqué mi vara, y jué tanto el jobiléo de varazos que le dí al dianche del pollinejo, que tomó la calle arriba sin detenerse un mimento.

Llegamos, por fin, a un sitio más ancho que too esto, 
que dizque era la Plaza, y había alli unos mozuelos con las melenas ataas, llenas de cal ó de yeso, que parecían Señores

sigun estaban de tiesos.

Empezaron a pegar

en unos como panderos

tales porrazos tan grandes

que souaban como truenos,

y más, que con lo que daban, eran manos de morteros.

Aquí jué donde el borrico

se golvió a espantar de nuevo

y tal, que aunque lo tenía

agarrao del cabresto,

con los brincos que pegaba

$y$ las cozes, era muerto

el querello sugetar,

jasta que los del surréo

dexaron de dar porrazos

que estonces se estuvo queo.

Acabao como ixe,

el rúo de panderos

y de pitos, al menute

se alborotó un hombrezuelo,

$y$ sin respondelle naide,

dando gritos muy de recio,

estuvo un valiente rato,

y al cabo los zagalejos

que alli estaban en la plaza:

Ajórquenlo, le ixeron.

Reb. Fso sería algun vando

de órden del Romano Imperio,

y no sabes lo que ixo?

Jos. Estonces no, el Mesonero

dempus me ixo, que era

un derito del Imperio

de Roma, en que se mandaba

que hombres, mugeres y viejos,

sin admitilles escusa,

al Puebro donde nacieron,

se juesen ... (aquí de Dios,

que ya me falta el aliento,

la llengua se me trabuca,

a dicillo no me atrevo,

pus me parece que ya

veo la joz en mi cuello). 
Reb. No te detengas, acaba, ¿qué es lo que manda el Imperio, que me has puesto en gran cudiao?

Jos. Que a toos como carneros mos descabezen al punto, que a nuestros Puebros lleguemos; mira tú qué pena esta tan a diestro y a siniestro, mandan así a sangre fría descabezar nuestros cuerpos: y estó que no me conozco, 10 con el gran susto que tengo: los greguescos se me caen, se me ha baxao el perjeño más allá de los tobillos, y lo más pior de aquesto, es, que tengo mal de marro, mas que estoo flaco y senseño.

Reb. No hay que aflegirse, Jusepe, que ese descabezamiento, no será como tú pescas, quizá será, y esto es cierto, que Octaviano a sus Vasallos, mos querrá echar algun censo.

Jos. Yo lo que sé, sigún ixo el gueno del Mesonero, que munchos de Nazaren y otras partes a aquel Puebro vendrían a escabezarse: estonces salí juyendo de la Ciá sin pararme, antes que un dianche de aquellos de las picas y bigotes se estrenase en mi piscueso.

Reb. No puee eso ser ansí,

que no es tirano el Imperio, ni Judea tiene culpa para un castigo tan recio, y mas gozando ahora el mundo de tanta paz y sosiego; pus Octaviano con nayde ha regañao en su tiempo, Como eres tú $\tan$ bozal, y de $\tan$ basto enteleto, ni entendistes el Pregón, ni tampoco al Mesonero; y dexando uno por otro, remendaron el caldero? 
Jos. Qué caldero, ni qué porra, ahora me parara a eso, estando ya sentenciao para el descabezamiento. Jarto ize que escurrirme y zamparme aquí de un guelo.

Reb. $Y$ al ganao no te vas?

Jos. Qué ganao, ni qué cuerno,

a pique que allí me tope

algun bigotón de aquellos,

y mos dexe a guenas noches, y si no me engaño, pienso,

\section{Mira al vestuario}

que por el camino vienen

dos bultos, huyamos luego.

Vanse huyendo, y por otra parle salen de camino San Josef y la Virgen.

35] S. Jos. Princesa Soberana,

Encanto de los Cielos, Luz temprana,

Arca del Testamento,

En conde está encerrado aquel portento,

Quisiera en esta vez ser poderoso,

Solo por frariquearos el reposo.

¡Oh si Dios vuestro Hijo dispusiera,

Que en mí todo el trabajo recayera!

Mar. Esposo venerado,

No te acongojes, cese ese cuydado:

Bien conozco, señor, que estos trabajos

Son regalos de Dios, son agasajos,

Con que su mano pía favorece

A quien, ni aún sierva suya ser merece,

Por lo qual voy contenta en sumo grado,

Siendo en ello mi Dios el agradado.

36] S. Jos. Pues si vais tan contenta, cara Esposa,

Con eso ya descansa, ya reposa

Mi corazón de pena tan aguda,

$Y$ de triste en alegre ya se muda:

Los fríos, las escarchas y los yelos

No me causan ya penas, sí consuelos.

Mar. En tal conformidad, Esposo amado,

Los pasos sigues de este Dios sagrado.

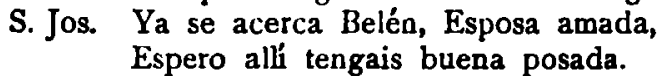

Mar. Lo que el Señor piadoso dispusiere,

Es lo que mi deseo siempre quiere.

Vánse.

Fin. 
III.

El Nacimiento de Nuestro Søñor Jesu-Christo.

\section{Coloquio Tercero.}

\section{Personas.}

La Virgen.

San Josef.

Jacob Pastor.

Josef Pastor.

San Gabriel.

Rebeca Villana.

Tres hombres.

Música.

Isaac Rabadan.

Salen Isaac y Jacob.

10

Isac. Pues, Jacob, qué tenemos

de Jusepe el enojao?

Jac. Apenas llegué a su casa, quando salio' con su palo

y quiso darme con él, diciéndome oprobios tantos, que no pue reucillo

a que viniese al ganao.

Isac. $\mathrm{Y}$ en qué se funda ese tonto ?

Jac. En que allá se le ha encajao

en su meollo brutal

que si viene al rebaño,

le han de costar la cabeza;

y no hay quien puea apeallo

de esta pitima que tiene:

su Mayre por decontao

le pegó una linda soba, y él tomó la calle abaxo:

viendo esto ansí, lo que jice, jué venirme como un rayo.

Isac. Qué inocencia de zagal?

el rumor que le ha cansao

el edito del Imperio,

. y es que el probecillo ganso, 
como está zerril, no entiende

si no es la palra del campo:

èl oyó encabezonar,

y como no está limao,

le pareció que era esto

echar la cabeza abaxo;

$y$ por eso el inocente

teme venir al rebaño.

Yo abajaré allá a la Aldea,

veré si pueo engañallo,

porque jace muncha falta,

10

para andar con ese jato.

Jac. Impusible me parece,

porque es un grande atestao,

$y$ aemás dice el muy tonto

que de jambre lo matainos.

Isac. Echaremos too el resto, quéate con el ganao. Váse.

Jac. En valde el viage dás, porque es simple rematao,

y como tambien se junta

el tener tan pocos años,

el respeto $y$ atenciones

ni aún los ha visto pintaos;

es como el otro que ixo,

jabrando en lenguage llano:

Quien con los niños se acuesta, amanece acomoao:

él allá se las jarree,

que yo me retiro al rancho.

Váse, y salen por otra parte Josef y Rebeca.

Reb. Porqué no quieres, Jusepe, cuentarme aquella trageria, que el Rabaan a la lumbre allá de noche te cuenta?

Jos. No te he icho que no pueo, no seas tan matraquera, si la pudiera dicir, a quién mijor que a tí mesma?

Reb. Porqué no pues dicilla?

no me ixiste en la Aldea,

que tenías que cuentarme

una historia que embelesa

los sentíos corporales

de muestra naturaleza,

pues dímela, que yo quiero

embilusar mis potencias. 
Jos. Si toico me trabuco,

y se me traba la llengua,

cómo te la he de contar?

tiene tantas menuencias,

la picara de la historia,

que era menester toviera

las letras $\tan$ remenuas, como aquel pozo de cencia de mi Mayoral Isacio, que rellata que rebienta; si tú lo oyeras jabrar una prática muy seria, embilusaa te quearas, ú la boca se te abriera, porque ice tantas cosas, que pasaron en la tierra allá en el tiempo de estonces, quando nuestra Mayre Evan salió de un gueso de Adán, $y$ aquello de la cullebra, que a too el mundo peldió, siendo un bocao la presa," que te asiguro, Zagala, quando el Rabaan mos cuenta estos sucesios, estamos

toos con la boca abierta; quixiera siempre escuchallo, pero luego el dianche oldena que uno se quee dolmío, quando a cuentarmos comienza; si no toviera esta falta de mimoria, yo sabiera munchísimos cuentecillos, y más de treinta novelas, por eso yo no me atrievo a cuehtarte la trageria, no sea que me trabuque por no tenella en la testa.

Reb. Cuéntalla como pudieres. y sea en qualquier manera.

Jos. Pus abre toa la boca y ansina estarás atenta. Habrás de saber, Zagala, como el Dios que mos sustenta, dempues de estarse enfinitos Siglos en su mesma Esencia sin comunicarse a nayde, porque naide había en la tierra, 
ni aún la tierra, ni aún el Cielo

eran entonces (que en fuerza

de su divino querer

lo crió too su inmensa

Proviencia en un menute),

determinó, porque era

de su agrao, hacer el hombre,

y tomando de la tierra

una miaja de barro

lo formó, sin que toviera

en esto mulestia alguna;

10

jizolo, y jué de manera

que debo decir, echó

el resto su Onipotencia,

pus lo crib tan perfleuto,

tan jermoso, de tan bellas

15

propiadades $y$ atrebutos

que jué semejanza mesma

de quien le dió tan gran ser;

su entendimiento, su cencia

20

jué tal que de lo criao

en el Cielo $y$ en la tierra

no se le escapaba naa.

Puso a su mano derecha

en señal de su alveirio

vivo fuego, $y$ a su izquierda

el agua, porque escogiese

lo que le tuviese cuenta.

Dióle nombre que jué Adán,

y para su conveniencia, porque no estuviese solo, gozando de una vivienda

(como era el Parayso)

de tantos árboles llens,

de tantas flores $y$ frutas

$\tan$ saborosas $y$ tan bellas,

determinó su Bondá

dalle, sin que él lo sabiera,

pentiparaa lo mesmo

que él, una compantera:

y que hizo? lo pilló,

40]

que dolmía a pierna suelta

$y$ al descudio con cudiao,

sin que el hombre lo sintiera

(pus se jacía a sus espaldas),

le sacó toita entera

de su cuelpo una costilla,

y la vistió de manera 
de carne, que en un vesible se jalló jecha, y derecha una moger muy bizarra, muy jermosa y muy perfleuta:

Ansí que Adán dispertó, y miró aquella doncella, le agraó tanto que ixo: „Vengais muy en horaguena, hueso de mis propios huesos, carne de mi carne mesma: el nombre que yo te doy, es Virago, por ser jecha y sacaa de Varón", por lo qual sin resistencia el hombre a su Payre y Mayre

dexará por poseella, y en una carne los dos serán una cosa mesma.

Estaban dambos en cueros y no tenían verguienza

ni reparo de mirarse:

ya se ve, que el causo era estar en gracia de Dios; pero en fin era inocencia el estar ansí en pelota, y lo mijor de esta cuenta, era no tener ni frío, ni calor, aunque les diera el Sol, la Luna ó el ayre; ni nayde les ofendiera, sino hubiera socedío aquella fatal trageria, jechura del mesmo dianche más sabio que la cullebra: metiosé en esta alimaña $y$ jué en hora $\tan$ adversia que engañó como más frágil a la moger (siempre quiebra la soga por lo delgao), y jué el causo, que en la huerta donde estaban, sigún dicen, había una gran Giguera ó un Camueso, y el Senfor pọr conocer su obedencia, les dixo que no comiesen ni un gigo, ni una camuesa, porque tenían veneno, y al punto que la comieran, 
se morian, y ayunando

ganaban indulugencia:

El dianche lleno de envidia, se allegó a la Mayre Evan

(que ansi se llamó Virago, porque discendemos de ella

los hombres $y$ las mogeres)

y le iso que comiera

de aquel árbol projebío, y sería estonces ella

una Diosa sabijonda,

que el bien 6 el mal que pudiera

haber, lo pescuñaría

sin nenguna inconveniencia:

La tonta se lo creyó

$y$ se engullo su camuesa.

¿Quién había de pensar

que una moger tan discreta

cayera ansí en el garlito,

$y$ de tal moo creyera

al payre de la mentira?

lo creyó de tal manera

la golosa, que al Marío

se jué arrestaa y resuelta

a oblígallo con jalagos

a que la fruta comiera;

el simple, aunque tan sabío,

tuvo poca resistencia,

pus apenas le rogó,

se jizo too una breva:

si Adán hubierá tenío

calzones, no la comiera;

tragó la fruta el simplón,

porque le rogaba Evan,

que es propio de las mogeres

antojaisas, ser necias:

apenas se la engulló

el probe Adán, quando a penas

tan grandes queó sujeto,

que no poía con ellas;

se vió desnudo, infeliz,

probe, lleno de miserias,

sin tener de que vestirse,

jasta que su Esposa Evan

supiera jilar, torcer,

para echar alguna tela;

por lo pronto echaron

de unas hojas de giguera 
y se taparon sus carnes,

porque les dió tal vergüenza

de verse en cueros, que huyendo

no acertaban él, ni ella

donde meterse: el Seffor

que vió tal inobediencia,

se vino paso entre paso

buscándolos, porque vieran

su desengaño, los llama,

y ellos llenos de pereza,

temerosos rejusaban

que los viese su Eminencia.

Por último respondieron

con escusas y frioleras

que no venían al causo;

él se disculpa con ella,

ella la muy relamía

percura el echarse juera,

diciendo. que la engañó

la Serpiente ó la Cullebra.

Por remate el Payre Santo, viendo tan grande insolencia, a la Cullebra maldixo, que anduviese por la tierra arrastrando; a la moger la castigó a estar sujeta

a su mario, y que siempre

toos los jijos pariera

con fuertísimos dolores;

a Adán por su ligereza

de cascos, lo condenó

a arar, a sembrar la tierra, si había de dalle fruto.

Dempues con gran deligencia, los echó del Parayso,

y que nunca más golvieran

a pisallo: para esto

puso en él de centinela

un Querubín con su espaa

en la mano, que chirrea,

para que nunca jamás

40

allí a los dos consintiera:

Jallaron estil al mundo,

sin posaa, ni progenia,

jasta que tuvieron fruto,

que jueron, si se me acuelda,

Caín, Abél, Set y tantos

que se peldía la cuenta, 
Con caa macho nacía al mismo tiempo una jembra; estos luego se casaban y aumentaban la progenia. Cansaos Adán y Evan, él de andar tras del arao, ella del juso y la rueca, y dambos de tener jijos, con muy pocas conveniencias, dempues de haber ya vivio tantos años en la tierra; pus dizque Adán ya contaba los novecientos y treinta, se les allegó la muerte, que Dios les dió por herencia, quando les dixo enojao, porque comieron camuesas: in pulvirem rebenteris. Muertos, pus, Adán y Evan, brujulearon eus Nietos de Dios una gran plomesa, y jué que había de embiar su mesmo jijo a la tierra, para borrar el pecao de Adán y las culpas nuestras. Con esto, al Payre de arriba los Payres de acá se quexan: dicían en un murmullo a la par viejos y viejas: que nos cumpla la palabra, que lo prometío venga. Si juera súpito el Payre, él perdiera la pacencia en ver que los que no pagan, executan por plomesas. En efleuto el Rabaán, como es un pozo de cencia, dizque ya no taldará en cumplirse esta plomesa, que se lo dá el corazón y yo igo, que si juera este pruigio en mis dias, estonces se me golviera el joicio de contento, y baylára de cabeza.

Reb. ¿Y dime, Jusepe, y qué diescendemos toos de Evan?

Jos. Aquesa es muestra desgracia, 
que por diescender de ella,

la cosa mala que jizo,

la tenemos siempre a cuestas.

Dentro ruido.

Qué ruío será éste?

Reb. Dios me valga $y$ me defienda,

Jos. Por mi vía que ha de ser

ó alguna Anima en pena,

$\delta$ algun bigotón de aquellos

de las alabardas tiesas;

10

de esta vez somos peldíos, ahora mos descabezan.

Reb. Ay, que es un Armao, voyme

de correndillo a la Aldea.

Váse corriendo Rebeca, y Josef va a hacer lo mismo, tropreza

en mano, vigotes postizos, y Josef tiembla al verlo.

Isac. Disfrazado de uniforme

y con la espada en la mano

(Aparte).

20

he de fingir a este simple

que vengo a descabezallo.

Jos. Ay Madre del alma mía!

Llora.

que me mata este Gavacho!

no habrá quien me favorezca?

Isac. Díme, cobarde villano ...

Jos. No me matosté por Dios.

Isac. Calla, simple, mentecato, que ahora me la pagarás por venirte del ganao.

Jos. Ay Señor! yo le imprometo golverme a él decontao, déxeme por vía suya, porque ya me estó finando.

Isac. Qué es dexarte? la cabeza ha de caer, gran bellaco, si no me dices muy pronto porque abandonaste el jato.

Como turbado.

Jos. Yo lo iré a somercé.

Ay, que estó desajornaol

Isac. Acaba, simple, responde, 
ó mueres aquí a mis manos,

porqué te has venio? díme.

Como turbado:

Jos. Me vine paso entre paso,

me vine ... porque me vine ...

me vine ... yó estó turbao,

sabe osté, porqué me vine?

pơqque el tiempo está pesao,

y osté ... si me diera escape,

me juyera como un gamo.

Io

Isac. ¿Todavía no me has dicho

porque dexaste el rebaño?

Jos. Porque lo exé y me vine,

y agora lo mesmo jago.

$$
\text { Vase, y le detiene }
$$

Isac. Qué es irte sin responderme?

Muy agrado:

Jos. Ea, no juegue de manos,

que eso está mal parecío

en los Señores Armaos;

acábese esta pendencia,

y vamos aquí apostando

a qual corre más ligero:

osté irá por ese lao,

y yo por éste...

Hace que se va, y muy enojado le deliene y le dird

Isac.

Deténte,

si ya no quieres ser pasto

de las aves de ese Cielo.

Jos. No me dé osté esus gritazos,

que no semos aquí sordos.

Se acerca a Isaac, y con blandura le dirá:

¿pregunto, señor Armao,

es conmigo esta quimera?

Isac. Con quién ha de ser, villano?

Jos. ¿No pudiera osté reirse

y no estar tan enojao?

Isac. Mas me irrita tu simpleza.

Jos. Pus eso está remediao,

por no irritalle, me voy.

Vase, $y$ le detiene

Isac. Primero te he de hacer tajos. 
Jos. Mijor juera hacerme texos, pus a sombra de texao me trae con esa espaa, $y$ esos vigotes tan largos.

Queosté con Dios, que me voy, porque me estan esperando.

\section{Váse, $y$ le detiene}

Isac. Irte tú? ni que lo pienses.

Jos. Pus yo me iré de impensao.

Isac. A dónde te quieres ir?

Jos. A mi casa como un rayo

a muarme de greguescos.

Isac. Pus te prevengo que al jato has de golver prontamente, porque si no, gran villano, poco será tu cabeza.

Jos. No, señor, tendré cudiao de irme al punto, como un trueno en estando ya muao de greguescos y polaynas.

Isac. Pus mira, que te hago cargo de esa palabra, tén cuenta de no hacerme algun engaño, porque al istante este acero vengará tan vil agravio. Váse.

Jos. Con una legión de pipas vaya el vigotón armao, y acá no guelva: qué tal? parece que mos bulramos, y dicía allá mi gente que era chasque lo del vando: vamos, en fin, a la Aldea, no sea que este borracho guelva, y el dianche lo tiente dexarme descabezao.

Váse, y salen por otro lado la Virgen y S. Josef de cammo.

S. Jos. Ya gracias a Dios estamos en la Ciudad de Belén; si os parece, amado Bien, por sus calles discurramos, algun pariente ó amigo, que nos franquee algun abrigo en tan prolixa ocasión. ¡ Oh sacra disposición de mi Dios, a quién bendigo! 
A ese gran Dios suplicad, ablande algun corazón, que movido a compasión de nuestra aguda congoja, en su casa nos acoja, aunque sea en un rincón,

Mar. Si es voluntad del Señor, que así los dos padezcamos, unánimes le sirvamos con paciencia y con amor.

S. Jos. Yo quiero llegar, Señora,

a esta casa de un pariente para ver si encuentro en ella que daros algun albergue, porque os veo fatigada, y el corazón se enternece, viendo que siquiera tengo el rinconcillo más leve, gracias a Dios de Israel, bendito sea para siempre.

Mar. Llegad, venerado Esposo,

a ver, si Dios halla albergue en sus mismas criaturas, a quien crió Omnipotente.

Llega San Josef a un lado y llama, y un hombre con voz aspera desde adentro responde.

S. Jos. A Dios gracias.

Homb. 1. Quíen?

S. Jos. ¿Amigo, quiere dar a un pobre huésped peregrino una posada?

Homb. 1. Hermano, por lo presente no puede darle acogida.

S. Jos. Mira, que soy tu Pariente, Josef de la Estirpe Regia

Homb. I. Mui poco me importa, sea como dice, mi Pariente; lo cierto es, que en mi casa no le puedo dar albergue, y asi debe retirarse, que eso es lo más conveniente, y no inquietar dando golpes en horas que todos duermen. 
Apartase S. Josef, y llorando dice lo siguiente.

S. Jos. Oh, Señor, quien no te alaba!

alabado seas mil veces.

Mar. Vamos, Esposo, a otra parte, y no asi te desconsueles, que esto permite el Señor, porque a los dos nos conviene.

S. Jos. Mi conformidad adora

del Cielo tan sacrosanto

permiso.

Vamos con Dios, llegaremos

10

a llamar en esta puerta, que es de otro Deudo, por ver

si hallamos en él clemencia.

Llama en medio.

Amigo, un pobre afligido

tienes humilde a tus puertas,

quien por Dios te pide y ruega,

le dés posada esta noche;

bien ves la grande inclemencia

20

de los yelos y los fríos:

hacedlo por vida vuestra.

- De adentro responde una voz áspera:

Homb. 2. Mire, pues, con lo que viene;

¿ habrán visto friolera

como ella, en tales horas

quebrándonos las cabezas

con golpes tan importunos?

¿que presente ó encomienda

46]

nos trae el bueno del hombre?

30

Ea, vaya a la otra puerta,

hermano, y mejor sería

cesára de dar molestia

al vecindario en las horas

que se descansa y sosiega.

S. Jos. Yo soy Josef, tu Pariente,

tan pobre, que es una azuela

carpintera mi caudal,

esta sangre de mis venas

es la tuya, tén piedad

de quien te lo pide y ruega.

Homb. 2. Mi Pariente dice que es.

que suposición tan necia,

tan impertinente y falsa;

pues quando lo conociera 
por tal, no sería entonces

de tan infeliz esfera,

grosero, importuno y pobre.

S. Jos. No es deshonra la pobreza,

quando Dios Sabio y Benigno,

es quien dispone $y$ ordena

distribuirla en quien gusta,

lo mismo que la riqueza.

Este Dios es quien te pide

que te muevas a clemencia.

10

Reponde enfadado.

Homb. 2. No he dicho que de aí se vaya?

retírese con presteza

y déxese de argumentos,

arrogancias y sobervias,

que si me enfada, saldré

y con su propia muleta

le enseñaré a moderarse

para llegar a mis puertas.

Apártase.

20

S. Jos. O Dios Sacro Omnipotente,

que no hay quien te dé acogida.

Vamos de aquí, gran Señora,

a casa de un poderoso

que me conoce, por ver

si hallamos en él socorro.

Vamos, lleguemos, Señora.

Mar. Josef, venerado Esposo,

no os aflijais que el Seffor

ha de mirar por nosotros.

Llama S. Josef al fin del vestuario, y uno con voz agrin le responde.

Homb. 3. Quién está aí?

S. Jof. Un Josef

pobre, aligido y lloroso,

que camina con su Esposa,

$y$ te pide por socorro,

le dés posada esta noche,

que el Cielo está rigoroso

con el yelo y con los fríos.

Homb. 3. Miren, qué bravo reposo?

¿ es éste mesón, hermano,

para venir de ese modo

pidiendo le dén posada?

váyase de aí muy pronto. 
S. Jos. No conoces a Josef?

47] Homb. 3. Ni saber quiero tampoco

quién es Josef, ni su Esposa.

Habrán visto más gracioso

lance? váyanse de al,

que tal gente no conozco.

S. Jos. Mi Esposa viene de parto,

dadme un rinconcillo corto:

por Amor de Dios lo pido.

Muy enfadado.

10

Homb. 3. Mejor está esotro tono:

ea, váyanse de aí, no dén lugar a un enojo.

S. Jos. Mira, que Dios te lo ruega.

Homb. 3. Hombre, no sea enfadado, dézese de porfiar.

Si quiere un albergue propio

para pobres como él,

omita esos alborotos,

vaya fuera de Belén

20

y hallará un Portal angosto,

medio hundido, alli podrán

hospedarse.

S. Jos. Sacro asombro!

qué es esto que por mi pasa!

Dios Niño, Hombre prodigioso,

¿ cómo permitís, Señor,

de un barro, de un frágil polvo

tanta ingratitud tirana?

quando Vos con tan piadosos

afectos a redimirle

del cautiverio horroroso

de la culpa venís hoy

y a librarle del demonio.

Música. El Cielo así lo dispone,

para que los hombres todos,

la pobreza $y$ humildad

estimen en grado heroyco.

S. Jof. ¡Benditos sean, Señor, tus juicios asombrosos!

Vamos, Esposa querida,

Mira a la Virgen, y ambos lloran.

vamos a este Portal corto, que el Cielo así lo permite para exemplo milagroso

de los sobervios del mundo. 
Mar. Vamos, pues, amado Esposo.

\section{Vánse.}

Mus. En un portal derribado, quiere el Todo Poderoso nacer, para confundir la sobervia del demonio.

Salen Isaac y Jacob, con mantas abrigados.

Isac. Qué fría que está la noche!

Jac. Aunque he estao arrebujao con la manta, no he poío entrar en calor ni un rato.

Isac. En los anos que he vivío, no me acueldo haber pasao noche más guena de fío.

Jac. El ticmpo está adelantao. $\mathrm{Y}$ dexando uno por otro, porqué no vino el muchacho?

Isac. Eso es largo de cuentar: si vieras que lindo chasco ha llevao el probecillo; en toa $\mathrm{mi}$ vía, rato como él no le he tenío; qué! si me hubiera alegrao, que por algun abujero lo hubieras estao mirando. Luego que allegué a la Aldea, supe que estaba en el campo con su helmana, y la jortuna me deparó alli un Armao que marchaba ácia a Belén; le peí su vestuario, y al punto me lo prestó; púsemelo, y disfrazao, con mis vigotes postizos, me partí para buscallo; salí al campo, y el simplón, que estaba tan descudiao, ansí que me vió, turbóse de tal suerte, que temblando no articulaba palabra; tal estaba amedrantao; su hermana puo escaparse, él no acertó a dar un paso, tan cortao estaba el probe, pus pensó que era un Armao de los que vió allá en Belén, 
que venía a escabezallo:

me jizo tantas plegarias,

yo con la espaa en la mano,

fengía bien mi negocio:

al fin el probe surrao,

por no verse sin cabeza,

me aprometió decontao

golver a su ubligación,

Jac. Y a dónde te lo has dejao?

Isac. A su casa jué a vestirse, no tardará, como un rayo vendrá, echando chirivitas.

Jac. Qué guen chasco le has pegao! si las cosas que tu tienes, tan estutas, es un pasmo.

Isac. ¿ $\mathrm{Si}$ lo vieras, qué cobarde, qué medroso, qué cortao estaba el probe zagal?

Jac. Qualquier cosa hubiera dao, por haber visto ese llance.

Josef dá voces dentro.

Los 2. El zagal suena en el plao.

Jos. Tío Isacio, donde está osté?

Isac. Aquí estamos, aquí estamos.

Jos. A dónde?

Isac. En la lomilla,

sube el repecho volando.

Sale Josef liado con manta.

Jos. A Dios, Caballeros.

Los 2. Hombre, que mozo vienes, que branco? estás gueno?

$$
\text { Le dán la mano. }
$$

Jos. Tan bellisemo.

lsac. $\mathrm{Y}$ tu gente?

Jos. Allá quearon.

Isac. Hombre, ¿para que has venío en esta noche al ganao con unos fríos tan grandes?

Jos. De allá salí bien trempano. pero me cogió la noche abaxote junto al plao, como jacía tanto yelo, jice candela, $y$ al raso, sin poello remediar, 
me dolmí como un capacho

ahora poco disperté

y vine traspagilando.

Isac. Capaz eres de dolmir

sobre un alfange afilao:

pensaba que no querías

golver más con el ganao.

Jos. Por poquito allá me queo,

para siempre sepultao.

Jac. Has estao malo, di?

10

Jos. Peor, que he estao encantao.

Jac. Encantao: cómo es eso?

Jos. Eso pie mas espacio:

si hay cachorrex́as ó migas

ó alguna cosa, comamos,

Isac. No están jechas.

Jos. Pus bebamos, por si entramos en calor: de frio estoy teritando.

Isac. Saca la bota, y dempues

jacer las migas, volando, porque amanta jace frío.

Saca Jacob de un zurrón la bota y la da a Isaac, y eiste la da a Josef, toma la bota y echa un trago.

Jos. Ea, señores, yo brindo

a la salú de un cuitao,

que ero.yo, porque me libre

su Magestá de un Gavacho,

que quixo de mí bulrarse:

mala pedraa en sus cascos. Bebe.

Isac. En los tuyos.

Jac. Ola, digo, que te la empinas, borracho.

Jos. Quitate allá, que esta noche pardies, si yo no me engaño, es la nocbe de la cosa

Isac. Porqué lo ices, muchacho?

Jos. Porque yo no sé que tengo: tengo un alegrón tamaño en mi alma, y en mi cuelpo, que no pueo desechallo: quita, que voy a beber.

Empina, y Josef se la quita.

Isac. Jusepe, no scas borracho, el alegrón que tú tienes, 
es lo que vas empinando.

Isac bebe y da la bota a Jacob, y bebe.

Jos. Ola, digo, Caballeros, que no es agua, vamos craros, parece que en la quadrilla estamos ya tres borrachos.

Toma la bota y la mira.

que guen beso le pegasteis;

pez con pez la habeis dexao:

una cosa se me ofrece:

curiao, que esta noche mando, porque soy el Rabaán, sende ahora del Rebaño.

Jac. Arriba se la ha subío.

Jos. Antes, de arriba ha baxao.

Jac. Guena está tu alma; ea, ya jabra desconcertao.

Jos. No por cierto, que ó la Groria a la tierra se ha baxao, ó la tierra se ha subio allá a la Groria volando, porque yo estó tan alegre, tan contento $y$ aquellao, que por la boca se sale el regucijo a puñaos.

Isac. Que presto se embriagó!

Jos. A jacer migas, muchachos, porque si no, con la porra os he de romper los cascos: ya han salío las Cabrillas;

Alza la cara.

vamos al punto; yo mando.

Isac. El zagal está penoso.

Jac. No se puee a los muchachos dar vino, para que beban.

Jos. Mírad, qué jaceis paraos? vamos a migar el pan.

Jac. Ea, pus, vamos volando, dónde está el pan?

Jos. En Belén lo tenemos tan barato, que diz que lo dan de gracia al probe necesitao, es $\tan$ floreao y bello, es tan sabroso y tan branco 
que es una groria comello.

Isac. Tu estás bien arrematao, en el zurrón está el pan, la sal y tambien los ajos: Jacob, los dos migaremos, trae tú la sartén del rancho.

Sienlanse los dos a migar, y sacan un hornillo, ajos $y$ un cuermo, $y$ Josef va deniro por la sartin $y$ dicen.

Jac. ¿El zagal no está perdío con el vino que ha empinao?

10 y mas que bebió muy poco.

Isac. En estando un borracho, le temo como a la muerte: temblando estoy del muchacho, porque como sin joicio, pue jacer un tentao,

Sale corriendo Josef con la sartén temblando despavorido, y ellos de oirlo se burlan.

Jos. Ay Tío Isacio! una pantasma

viene revoloteando

por esos ayres, parece

un pajarraco encarnao, viene echando tantas chispas que too el monte está craro, sigún las luces que arroja: si vendrá a descabezarnos? las ovejas y aún lus perros, toas se han espaventao: acorralaas están. Los carneros han tomao por el monte abaxo: el burro pensó que era algun lobaso, y de mico, el probecillo too se ha escagajonao.

No hacen caso $y$ siguen migando.

Isac. Calla, tonto, ése es el vino.

Jos. Qué vino, ni qué capacho: levántate, y lo verás.

Isac. Ahora estamos bien sentaos, dexa la sartén, y duelme el lobo que has agarrao. Qué no me crees?

Jos. Qué no me
Isac. No te creo. 
Al son de instrumentos baxa de pronto $S$. Gabriel, y los dos sueltan $l$ pan $y$ tiemblan, $y$ Josef burlándose de ellos, aice.

Jos. Ya está aquí: bien empleao, porque no querían creerme, culpándome de borracho.

S. Gab. Mirad, Pastores dichosos, que no intento amedrantaros, pues soy Angel del Señor, que vengo a evangelizaros el mayor gozo del mundo, y es, que ya teneis Humano a Dios, que para vosotros hoy ha nacido: alegraos, porque como Salvador viene a la tierra a salvaros. En la Ciudad de David teneis a este Dios Sagrado: la señal que os doy, es ésta: hallareis en un establo, envuelto en pobres pañales, un Infante Soberano, id a adorarle, Pastores.

Mirando adentro.

$Y$ vosotros elevados Espíritus Celestiales, celebrad tan sacrosanto Mysterio de Nacimiento de nuestro Dios Humanado.

Váse.

Mús. Gloria in altissimis Deo, $\&$ in terra pax hominibus.

Vueloen en st los Pastores atonitos, y Josef les dice.

Jos. Digo, estaba yo borracho? eso es como ixo el otro: Los locos y los mochachos siempre icen las verdaes.

Isac. Qué mancebo tan gallardo! dexad las migas, $y$ toos vamos a ver ese pasmo.

Jac. Y el ganao quea solo?

Isac. No tengas de eso codiao, que ese Niño pruigioso, lo guardará bien guardao; aemás que el que a Dios busca, 
too lo dexa arrumbao.

Le alvierto a ostees, caballeros,

que delantre de Dios vamos,

y así tener gran respeuto

a un Señor tan Soberano.

A tí te encargo, Jusepe,

que tengas muncho codiao,

no te se vaya la mula,

y sueltes un garrapato.

Jos. Ola, igo, y no se lleva

10

a ese Niño algun regalo?

Isac. Razón es, que se le lleve,

y ansí será muy del causo,

se le presente manteca,

miel y un Cordero trempano.

Jos. Y tambien los isturmentos

músicos para alegrallo;

yo llevaré la zambomba,

las castañetas Isacio

y Jacobo las sonajas.

20

Isac. Ea, compañeros, alto, vamos a ver ese asombro.

Jos. Y mientras, vamos tocando.

Tocan y vánse baylando, descúbrese el Porlal. Estará el Nino en un Pesebre adornado y con sus pajas, envuello en sus mantillas, $y$ a los lados la Virgen, $y$ San Josef, arrodillados en contemplacion, y San Gabriel, y canta la Música.

Mus. 1. Ángeles y Serafines, al Nacido de Maria, en estas humildes pajas, le alaben y le bendigan.

Entonen en dulces Coros

Sagradas Inteligencias.

Música por muchos.

Gloria a Dios en las Alturas, y paz al hombre en la tierra.

Mar. Hijo de mi corazón! ¿es posible, Dueño mio, que siendo $\tan$ poderoso, os veais $\tan$ abatido? ¿así dexais esos Cielos por este Portal hundido? la Gloria por la pobreza? qué pobre venís al mundo! qué abatido, Dueño mio! Conceded a los mortales, 
por quienes habeis venido,

voestra santísima gracia, y que os sean agradecidos.

Música por muchos.

Gloria a Dios en las Alturas y paz al hombre en la tierra.

Suenan instrumentos pastoriles, y salen los Pastores con los presentes, que expresarán sus versos.

Isac. Colad tras mi, compañeros, éste $\sin$ dua es el Niño.

Jac. Válasme, Dios, qué jermoso! no he visto Niño $\tan$ lindo!

Jos. Voto a pris, que es mi tocayo el Payre del Chocorrito.

Isac. Cudiao no te se vaya, Jusepe, algún desatino.

Jos. Quién me lo ixera a mi, quando en Nazarén mos vimos; ¿se acuelda osté, Tío Jusepe, por más señas que el borrico tambien iba en mi compaña, y estaba osté con un brío, aserrando un palo gordo, más grueso que el mulro mío? Yo me alegro, Tío Jusepe, que lo haya Dios escogío, para que sea su Payre. Qué bonito es el Choquito! sin dua que me conoce, pus me mira con ajinco: no lo arreparais, mirad, $y$ el Zagal es noblecico, que no llora, y mas que está arreciico de frío.

Dios lo bendiga: ajii ... ajoo ... mi chocorrotico, bien haya quien lo parió.

Isac. El dirá mil desatinos: mira, que es Dios, mentecato.

Jos. Dexa, que esto es un carino; pus miren tambien la Mayre, qué rostro tiene tan lindo, y es criaturita: pardiez, que la Mayre del Choquito, es aquella Nazarena, que allá en la montaña vimos 
los otros días: Señora,

me alegro haya osté salío

con toa filiciá

de la parición del Niño;

quiera Dios lo vea Osté

jaciendo como imagino

a too el mundo mercees,

que para eso ha venío.

Jac. No ves, que despelotao

está nuestro Jusepillo!

IO

miren tambien como sabe

el tontillo sus complíos.

Isac. Como es inocente, tiene vara alta con el Niño.

Jos. $\mathrm{Y}$ qué jacemos paraos?

Isac. Tén un poco de joicio.

Jos. Qué joicio, ni qué alforja:

Jacob, toca el panderillo,

baylaremos el jíndango

a la salú del Choquito.

20

Jac. Por eso no queará,

que echaré yo por mi Niño

too el resto en esta noche.

Ea, baylemos con brío.

Tocan y baylan, $y$ en acabando dice Josef.

Jos. Agora será del causo

que caa uno a mi Nifoo

le iga de su calletre,

alguna copra, ó dijío:

sea Isacio el manijero,

que es de los tres el layno.

Isac. Pus allá voy, Caballeros.

\section{Dice al Nitio en pié.}

Aunque Niño te veo,

tan probetico,

te creo un Dios tamaño,

pero muy rico;

porque es muy cierto,

que aunque probe, eres Jijo

del Payre Eterno.

Jos. Qué gueno ha estao, qué lindo.

Jacob, encaja tú agora.

$$
\text { Al Nino. }
$$

Jac. A conquistar baxastes todas las Almas, 
para reynar en ellas,

pero sin armas:

porque yo igo,

que hará juir tu Nombre

al enemigo.

Jos. A ver, Jacob, qué sabío!

agora me toca a mí:

$y$ por lo tanto a mi Niño,

le he de endilgar dos coprillas;

atención, que ya las igo:

10

Escuche Osté, Tío Jusepe,

que está Osté medio dolmío.

Dice al Niño.

$Y$ mosotros primero

semos llamaos,

para miraros Dios,

pero Humanado:

porque tú quieres

darmos la primacia,

por ser probetes.

Ya que tamaña dicha

los tres tenemos,

encájanos, mi Niño,

allá en los Cielos;

porque se iga

que los que acá te ven,

allá te almiran,

Esto sí que es dicir copras:

- de los demás yo me río,

$y$ cudiao, que no soy

30

ni leío ni escrebio.

Isaac posirado.

Isac. Dulce Pastor de las Almas,

a quien venero rendío,

Dios y Hombre a un mesmo tiempo,

pus tan liberal has sido

para con nosotros, siendo

unos probes desvalíos,

llamándonos tu Bondá,

con ser de tal honra indignos.

por muestros grandes pecaos:

amparadnos, asestidnos

agora $y$ en nuestra muerte;

perdonad, que atrevío

os ofrezca este presente

de miel, y con el rendio 
mi corazón, que os venera

como a mi Dios enfinito,

Yo quisiera presentaros

otro dón más esquisito,

pero al fin es misterioso,

porque con la miel, Dios mio,

sabreis elegir lo gueno

en el mundo a que has venio:

dadme vuestra santa gracia,

para que acierte a serviros.

10

Jos. Jacob, como se conoce

que el Rabaán es leío;

mira al lo que ha ensartao

de conceutos y dixios;

agora veré, si tú

eres tambien $\tan$ reicho.

Jacob postrado.

Jac, Pruigioso Niño Dios, postrao a tus piés benditos teneis un humilde esclavo, deseoso de serviros; alabo tu gran Bondá, pus siendo yo un probe indigno

de estar en vuestra presencia, os dignasteis compasivo, llamarme, para que aore tu Humaniá, Niño mío.

Perdonadme, que os ofrezca, en seńal de mi cariño, este tarro de manteca, que aunque no es presente dino

de tu grandeza, a lo menos

es don sinificativo, de que sabrás reprobar en habiéndola comío, too lo que juere malo.

Por lo tanto te soprico, que a mí me jagais un Santo, para que sea elegío.

Jos. Qué tal le parece a ostees?

miren Jacob qué llocío

ha escapao: no creyera, si yo no lo hobiera óio, que tales cosas dixera, un hombre $\tan$ encogio. $\mathrm{Ea}$, ajuera, rancho aparte, porque agora yo me sigo. 
Dios dé a ostees muy guenas noches, Sefiores: yo les estimo, como si yo lo comíra los favores tan complíos que mos han jecho, embiando a la majaa aquel Mozito

Sentala al Angel. con el recao de María; no perdono al Señorito, quando en el ayre lo ví, 10 volando tan encendío, el susto que yo pasé; en fin, ya pasó, Dios mío, agora vamos al causo.

Arrodillase.

Primeramente os soprico, me libreis de los Armaos, de aquellos hombres malinos de los vigotes tan largos, que no se topen conmigo y me corten la cabeza; antayer por poquito me ha dexao a guenas noches uno de ellos, jué un pruigio el escapar con pellejo, si no, ya yo estó morío. 'Tío Jusepe, el ojo alerta, mirosté, que se lo aviso. Por lo que toca al regalo, aquí está este Corderillo, flaquillo está, pero al fin, algo es algo, no es malito; más da el duro que el desnuo; si juera el Rebaño mío, el Manso con su cencerro volando hubiera venío;

a bien que Vos soys el Manso, el Pastor, el Corderito, y mosotros los Carneros; apacentadnos, Dios mío, mientras en el mundo estemos con tu gracia y tus auxilios, para que en saliendo de él, demos un valiente brinco 
a la Groria, donde reynas

por los siglos de los siglos.

Se levanta.

Mar. Yo os agradezco, Pastores, el obsequio que a mi Hijo

habeis hecho: conoced, que entre todos habeis sido los primeros, que Humanado en este mundo lo han visto; estimad tan gran merced, no olvideis tal beneficio; sed buenos en vuestra vida, sirvéndole muy rendidos, amándole en vuestras almas, que siendo franco $y$ benigno, os llenará de su gracia $y$ de bienes infinitos.

Cierrase el Portal.

Mús. Gloria in Altissimis Deo, $\&$ in terra pax hominibus.

Fin. 
IV.

La Manifestación de $\mathbf{N}^{\text {tro }}$ Señor Jesu-Christo.

\section{Coloquio Quarto. \\ Personas.}

San Melchor Rey.

S. Gaspar Rey joven.

Herodes Rey.

Los Ministros.

S. Baltasar Rey negro.

San Gabriel Arcángel.

Acompañamiento.

Josef Pastor.

Rebeca Villana.

Música.

Mús. Venid, mortales, venid,

10

llegad, llegad con respeto, que vais a ver a tres Reyes adorar al Rey del Cielo.

De Persia, Arabia y Sabá

salen con igual contento,

siguiendo una hermosa Estrella

que es signo de un gran Lucero.

Ella los viene guiando

por esos valles amenos,

para que adoren postrados

20

a un Rey más sabio que ellos.

$Y$ traen reconocidos

$57]$

a los favores del Cielo

que ofrecer a este Rey Niño

dones de Oro, Myrra, Incienso.

Amantes le adorarán

como a Dios y Verbo Eterno,

como a Hombre natural

y como al Rey más Supremo.

Salen Josef y Rebeca.

Reb. Agora que estamos solos, sin que mos oygan las viejas, que murmuran quanto pasa

Beiheft xur Zeitschr, t. rom. Phil, LXXII. 
al pié de sus chimeneas, quixera que me cuentaras, para que yo lo sabiera, qué jué lo que te pasó, velando allá las ovejas

la otra noche con un Ángel, que te espantó de manera que desmamparando el jato te juiste a una grande jiesta.

Jos. - Eso, Rebeca, jué un pasmo;

10

no tuve noche más guena,

te asiguro que en $\mathrm{mi}$ vía

he baylao más de veras:

si tú vieras, jué una boa

mijor que las de la Aldea.

Yo no sé lo que tenía

en mi cuelpo y en mi llengua,

a montones los dixíos

se me iban de la testa,

$y$ toos mis camaraas

20

dicían mil cuchufletas.

Reb. Quién era el Novio y la Novia?

Jos. Agora sales con esa?

¿Qué no sabes lo que pasa

en el Reyno de Judea?'

ya ha venío el gran Masías.

Reb. ¿Jué el que ixo Tía Jusepa?

Jos. Ll mesmo que viste y calza, ha nacío en nuestra tierra.

Reb. Y quién es el Novio?

Jos. El Niño.

Reb. No igas esa simpleza.

Jos. Aunque chiquito es más viejo

que toa tu diescendencia.

Si es Dios el grande Masía,

qué? te parece que era

un qualquiera Zagalejo

de aquellos de nuestra Aldea?

Reb. Si eso es ansí, ya lo creo;

too lo puee su Grandeza;

$y$ areparaste en la Novia?

Jos. Si esta juera de Judea, cómo la había de mirar?

Reb. Con que será jorastera?

lo que habrá en la Palestina

de regucijos y jiestas!

Jos. Siguro está que las hayga.

Reb. Pus no ixo T'́a Jusepa, 
que en viniendo el gran Masías

correrían por la tierra

arroyos de leche $y$ miel,

y que el lobo con la oveja

se verían muy amigos:

ansimesmo las Potencias

harían la Gataplasma

a tan grandota Ecelencia,

y que toos gozarían

de paz y guena cosecha?

10

conque si ha venío ya,

habrá esto de por juerza.

Jos. Calla, tonta, que no entiende

tu calletre esas aquellas.

- Reb. Si no es cierto lo que igo, que me corten las jorejas.

Jos. Es verdá; pero tu entiendes

la cosa como ella suena,

¿quieres que yo te lo esprique, para que mijor lo sepas?

has de saber que la gente

de por acá de Judea

son toos unos canallas,

nenguno paga las deudas,

son ingratos, traicioneros,

falsos, de mala concencia.

Pus dice mi Rabaan,

que a nengunos más plomesas

jizo Dios, que a los Judíos,

y entre tanta alma pelvelsa,

no ha topao nuestro Dios

gente que se lo agraezca.

Viendo, pues, el Payre Santo, que los de acá de esta tierra no saben agraecer,

ni pagar jieles las deudas,

no ha querio que su Jijo

se encasulle en esta tierra,

porque sabe ya muy bien

del pié que toos cojean;

$y$ ansina ha determinao

que sea una jorastera

la Novia del gran Masias, que lo agasaje y lo quiera.

Reb. ¿Pus por acá no ay mogeres muy jermosas y muy bellas?

Jos. No arrepara eso el Masías;

lo que quiere, es, que lo crean, 
que lo estimen y lo sirvan,

$y$ esto no hay en esta tierra.

Reb. ¿Pus toos no deseaban

que el gran Masías viniera?

Jos. Es verdá, pero engañaos

asperaban a su Alteza,

que viniera de otro moo,

con munchísima grandeza,

no del moo que ha venío

con estremaa probeza,

10

y por eso. no lo quieren, siendo el Masías de veras.

Reb. Quién dice que no lo quieren?

Jos. Yo lo igo: éstame atenta.

Al gran Plofeta Daniel

(dicen las Divinas Letras,

y tambien el Rabaan),

jizo Dios una plomesa

una vez que estaba triste,

por querer ir a su tierra;

y Dios para consolallo,

le ixo de esta manera:

porqué estás ajumentao?

déxate ya de tristezas,

que el Masías verdaero

te quitará las caenas

y a tus Paysanos tambien:

no han de pasar de setenta

Jeomaas $\sin$ que vestío

de la carne humana venga.

Bien saben toos los Dotos

que esta plofecia era guena, y saben tambien que el tiempo

se ha cumplío ya a la letra,

$y$ con too eso han dexao

que este Dios Niño naciera

en un Portal derribao

entre de humildes bestias,

sin más cuna que un Pisebre,

que es un dolor, una pena

ver a un Niño tan jermoso

con tantísima probeza.

Reb. ¿Pus porqué su Payre y Maire

no avisaron de que era

ese Niño el gran Masias?

Jos. Conque aquella noche guena estuvieron en Belén, pidiendo de puerta en puerta 
por Dios que lo recogiesen aquella noche siquiera, porque venía de parto la Mayre de su Excelencia, $\mathrm{y}$ toos les respondían que se jueran, que se jueran; como se acercaba al parto, y veían la fiereza de toos nuestros Paysanos, abajaron la cabeza, se vinieron al Portal, y estonces la Mayre bella mos parió allí al Niño Dios; conque mira si en Judea quixieran al gran Masías, jicieran las deligencias, si aqueste Niño era ú no, que no más de que lo vieran, como yo lo confesaran por Dios del Cielo y la tierra; y estando, como ya he icho, cumplía al pié de la letra la plomesa de Daniel: vés aí porque las jiestas no se jarán por acá, que serán en otras tierras.

¿Conque ansí será mentira

lo que ixo Tía Jusepa?

Jos. No es mentira, pero yo, lo que sé, es que no habrá jiestas.

Reb. ¿Los ríos de miel y leche correrán por nuestra tierra?

Jos. Como que ya están corriendo; pero no hay quien de ellos beba en la Ciá de Belén ni en el Reyno de Judea: esos ríos que te ixo la otra noche Tía Jusepa, salen del tal Mamuelico (que ansí se llama su Alteza) por lo dulce y lo suave, que viene vertiendo pelras: pero acá, como te igo, no arrecojen ese netar, porque no quieren creer que nace Dios en probeza. ¿Y díme, Jusepe, y qué, los lobos y las ovejas 
se juntarán por acá

ó eso será en otra tierra?

Jos. No entiendas tú los cameros,

los lobos ni las ovejas;

no es eso lo que ixeron

en sus libros los Plofetas;

sino que como este Niño

viene a quitarmos la guerra,

como Préncipe de Paz,

no. tendremos más peleas

10

unos con otros, seremos

amigasos muy de veras.

Reb. ¿Y no se le rendirán

a sus plantas las Potencias?

Jos. Ansí diz que el Rabaan

lo contb Davil Plofeta;

que de Trasis y Sabán, de la Arabia y las Isletas vendrán sus Reyes rendíos

a baxarle la cabeza.

Reb. ¿Y porqué ha nacio Dios

con tantísima probeza?

no pudiera haber nacio

con Magestá y con Grandeza?

Aparece al paño una Estrella.

Jos. En eso conocerás

6o]

quien es Dios y lo que oldena:

quiere enseñar a los hombres

a que amemos la probeza.

Reb. Oye, Jusepe, no ves?

por allí viene una Estrella.

Vuelven la cara al paño.

Jos. Por donde?

Reb. Por el Oriente.

Jos. Válasme Dios, qué Cometa! mira allí qué jopo tiene, parece cola de Yegua.

Reb. Qué será aquello, Jusepe?

Jos. Quizá será que en pos de ella vendrá la Novia del Niño.

Reb. Pus mira, vamos a vella.

Jos. No ves que viene muy lexos? una cosa se me acuelda; vamos a Jerusalén, que alli se verá más cerca. 
Vanse corriendo, ocuiltase la Estrella, y al son de instru- I mentos baxa San Gabriel.

S. Gabr. Oye, Pueblo Gentil, suspende el llanto,

Dexa ya de sentir, cese el quebranto:

Conviértase la pena en alegría,

Pues del Claustro Virgineo de María

El de nueva Salud Autor Divino

$\mathrm{Ha}$ nacido a enseñaros el camino.

Este es aquel gran Dios que a los Judíos,

Por ser su Pueblo, daba grandes bríos

En todas las batallas: ya el Dios Fuerte,

De hoy más a vuestra ayuda se convierte.

Ya va a espirar la noche tenebrosa,

$Y$ vereis de ese Sol la luz hermosa.

Desde ahora os elige (qué gran dicha!)

Por su Pueblo escogido, y la desdicha

Será para el incrédulo Judío,

Ingrato, desleal, infiel é impío,

Que queda a su dureza abandonado

Y por solemne voz desheredado

Por rebelde a su Dios y descreido;

Dígalo este Pesebre, en que ha nacido:

(Qué asombro!) por no hallar quien le acogiera

En toda la Ciudad rebelde y fiera.

Por tanto hoy a vosotros se convierte,

Pues de éste lo que espera es dura muerte.

El os ha de amparar si le creeis,

Como así yo aseguro que lo hareis.

El será vuestro Dios en adelante,

$Y$ vosotros su Iglesia Militante.

$\mathrm{El}$ os ha de estimar de tal manera,

Que estará con vosotros aunque muera.

La Ley que ha de imponeros es suave,

$Y$ fielmente observada, será llave

Que os abrirá las puertas de su Reyno,

Morada de la paz y gozo eterno.

Hoy ya por él comienza vuestra dicha, $\mathrm{Y}$ del Judayco Pueblo la desdicha.

Hoy, en fin, es el día en que este Rey

Graciosamente os nombra por su Grey.

Así templad el llanto y sentimiento:

Múdense vuestras penas en contento:

Puesto que hoy han de verse del Oriente

A los piés de este Nifo Omnipotente

Tres poderosos Reyes, gentes vuestras,

Dando de su gran fe gentiles muestras.

Por Hombre y Dios habrán de confesarle

$\mathrm{Y}$ por su Rey tambien han de jurarle: 
Entonces el gran Dios reconocido

A lo bien que estos Reyes han cumplido, En ellos y por todo el Gentilismo,

Derramará de gracias un abismo.

Ya no os llamo Gentiles, sí Christianos,

Pues soys para con Christo tan humanos;

$\mathrm{Y}$ pues $\tan$ fieles soys y $\tan$ piadosos,

$\mathrm{Ah}$ ! que tambien sereis los más dichosos.

\section{Váse.}

Mús. En el Portal de Belén

IO

se ha de ver hoy repudiado

de Dios el infiel Hebreo,

$y$ el fiel Gentil ensalzado.

Salen los tres Santos Reyes, y Acompañamiento.

Melch. Aqui en esta gran Ciudad, que es Metrópoli del Reyno,

la antigua Jerusalén,

Corte y principal asiento

de los Reyes de Judea,

aquí es donde encontraremos

al nuevo Rey que buscamos;

pues siendo de los Hebreos

Soberano el que ha nacido, será aquí su Nacimiento;

la Estrella asi nos lo explica,

aunque con mudos acentos;

pues habiéndose ocultado

al llegar a este gran Pueblo,

de nuestra vista, es señal

de estar en el tal Portento.

Entremos, pues, si os agrada,

$y$ al primero que encontremos,

le podremos preguntar.

Gasp. Eso es lo mejor: entremos

a buscar por esas calles

lo que anhela nuestro afecto,

lo que con tan viva fe

arrastró nuestros deseos,

sin temer las inclemencias

que nos ha ofrecido el tiempo.

Balt. Entremos, pues, y verán nuestros ojos el Objeto, que de tan lejas Provincias aquí les trae prisioneros: finalmente nuestras ansias se acabarán, en teniendo 
presente al recién nacido

Príncipe de los Hebreos.

Vánse, $y$ por otra parte salen Josef $y$ Rebeca corriendo.

Reb. Por aquí, si no me engaño, pienso que han ío, volemos.

Jos. Aspérate, Rebequilla, no ves, parece muy feo que corras de esa manera; aguárdate, pues yo pienso se han entrao en la Ciá; estémonos aquí queos, 10 no sea que cargue bulla, y quizá mos ajoguemos; luego habrá más poca gente en jartándose de vellos, y ansina con desajogo, toitico lo lograremos.

Reb. ¿No arreparaste, que iban dos brancos, y uno muy negro, subios en Animales que no los hay en el Puebro?

$y$ toos son jorobaos, pero no chicos de cuelpo, $y$ tienen unos gañotes más largos que los Cigüeños.

Jos. Quizás serán Albestruces.

Reb. ¿Qué sé yo? vámonos luego a ver estos Alimañas, y a los brancos y a los negros; llevaremos que cuentar en llegando a nuestro Puebro.

Jos. El dianche soys las mogeres, tan coriosas que no hay de eso.

Reb. No ves, Jusepe, que estoy agora en los años tiernos de mi guena jumèntú, y es propiadá de mi sexo ser coriosas.

Jos. ¿Y pregunto, qué se adelanta con eso?

Reb. Ver toas las noveaes.

Jos. Pus voy a cuentarte un cuento que le socedió a una niña: (no era de las de estos tiempos).

Reb. Pus vaya, que atenta escucho.

Jos. Digo ansina: va de cuento:

Has de saber que éste era 
y jué, si mal no me acueldo,

Patrialca: éste tenía

doce jijos ya mozuelos,

y una jija solamente

de quince años y medio,

que era en la casa de toos

el jugnete y el recreo:

ésta se llamaba Dina,

era jermosa en extremo,

(aunque, como ixo el otro:

Años quince no son feos),

pus vamos a que una tarde

le dió a la niña deseo

de salirse a pasear:

endilgóse a cierto Puebro,

cercano de su cabaña,

sin llevar otro preteusto,

que ver los trages $y$ moas

20

de las mozas de aquel Puebro.

Pus quando se paseaba

con este entretenimiento,

para su alversia jortuna,

la vió un cierto Caballero,

que se llamaba Siquén,

jijo del Rey: al mimento,

que la vió este Señorito,

se enamoró, y jecho un fuego,

se abalanzó a la mozuela

como un lobo carnicero,

jizo de ella lo que quixo,

dexando su honor muy feo:

al menute como un rayo

llegó esta noticia presto

a su Payre y sus helmanos.

Mira tú, qué sentimiento

tendrian! como eran mozos,

se llenaron de veneno:

juntaron de sus Pastores,

Gañanes y Ganaeros

un montón, y se endilgaron

a la Ciá, en el mimento

jueron pasando a cuchillo

a quantos en ella vieron.

Entraron en el Palacio,

y a toos me los barrieron, al Rey Hémor y a su jijo, 
agresor de aquel mal jecho.

Agarraron a la helmana, $y$ al rancho se la truxeron, no como de allí salió, quando coriosa al paseo, jué a buscar su peldición, sino jecha ya escarmiento de las mozuelas coriosas, aficionaas al jopeo: conque mira tú, Rebeca, si el ser coriosas es gueno.

Esta níña por salir en una tarde a buréo, acarreó su deshonra, y dempues de este tropiezo, tantas muertes y desgarros; no hay como el estarse queos, que una moza recataa está mijor en su encierro.

Reb. Eso es gueno para locos.

Jos. Y más gueno para cueldos.

Reb. Déxate ya de sermones, que has estao majaero.

Jos. En dando en las matauras, son amargos los consejos.

Reb. Vamos a ver a esos hombres, que ya el Puebro estará queo.

Jos. Joraa por esa trocha, $\mathrm{y}$ ansina te iré siguiendo.

64] Vànse, y por otro lado salen Herodes y el primer Ministro. 30

Her. El veros hoy tan temprano, en gran cuydado me ha puesto.

Min. I. No lo noteis, gran Señor, que teneis en vuestro Reyno, mejor diré en vuestra Corte, tres extraños Caballeros, cuyos magníficos portes son de Reyes, según pienso, pues ciñen Diadema Real, empuñan dorados Cetros, arrastran púrpura; en fin, estas señales, su aspecto, el equipage y grandeza que obstentan, son más que ciertos indicios de ser Personas que dominan otros Reynos: en paz vienen, según muestra 
el corto acompañamiento que traen de sus criados y algunos Alabarderos.

La Ciudad está confusa, en corrillos todo el Pueblo, al ver tan extraño caso, tan no esperado suceso. Admiran sus vestiduras no vistas en este Reyno, sus riquezas, sus criados, todo su acompañamiento, hasta sus cavalgaduras, que su andar es ir corriendo, tan veloces como el ayre, su estatura es de Camello, que según he discurrido, por lo que leido tengo, parécenme Dromedarios, por su paso, hijos del viento: y lo que más..., ó Serior,

a la Corte y a mí han puesto en confusión, es oirles .. aquí mi decir suspendo, pues no sé cómo explicaros lo que ha de ser ofenderos; $y$ así postrado $y$ rendido a vuestras plantas espero,

Se arrodilla.

que me concedais licencia para decir lo que siento. en mi alma, referir lo que intentan saber ellos.

Her. Levantad y proseguid.

\section{Levaintase.}

con brevedad, que estoy puesto en zozobra, no seais con digresiones molesto.

Min. Pues, Señor, el Pueblo todo de confusión está lleno, al oir a estos Magnates, que con descaro y sin miedo, públicamente preguntan: En donde ha nacido el nuevo Monarca de los Judíos que esperaba el mundo entero? 
porque en el Oriente vimos

(dicen) un grande Lucero,

que claramente nos dice

su importante Nacimiento;

a donde está? que venimos

desde nuestros largos Reynos,

a visitarle, a ofrecerle

obsequiosos rendimientos

de humildes adoraciones

y muy debidos respetos.

Esto, Señor, es en suma,

ro

65]

lo que me ha traido a veros

más temprano que otras veces:

ved si alguna culpa tengo

en haberme anticipado

a deciros lo que presto

es fuerza que lo sepais,

por ser notorio en el Pueblo.

Mandadme lo que gustareis,

que vuestras leyes deseo.

20

Herod. Y la Nobleza, qué ha dicho?

¿qué ha respondido ó qué ha hecho,

al oir que preguntaban

por ese Monarca nuevo

que ha nacido, y yo lo ignoro?

Min. Nada, Señor, respondieron,

quando el caso tan estraño

a todos tiene suspensos.

Herod. Pues luego al punto citad

baxo de Real mandamiento,

so pena de mi furor,

a los Escribas del Pueblo,

Príncipes de Sacerdotes,

y que vengan todos luego

sin tardanza a mi presencia:

y díles que les espero

en $\mathrm{mi}$ retrete; cuidado

con observar mi decreto.

Min. Con la mayor diligencia

voy, Señor, a obedeceros. Váse.

Herod. Yo sabré con evidencia

quién es este Infante nuevo,

Monarca de los Judíos;

y a pesar del Mundo entero, he de beber su sangre,

porque sepan en mi Reyno

que yo soy el Rey Herodes, su legítimo Supremo. 
Vase, $y$ sale Josef $y$ Rebeca.

Reb. Jusepe, si no me jarto de ver a los Extrangeros:

¡qué mozetón es el uno, branco y rubio! pero el negro

es quien me jace más gracia

vello que va $\tan$ repleto

subío en el Alimaña, con dos varas de piscuezo, el otro que va delantre,

se conoce que ya es viejo, porque tiene el pelo cano, $y$ arrugas en el pellejo.

Oyes, ¿qué valdrá la ropa que traen sobre sus cuelpos?

Jos. Eso es un caudal: valdrá más de millenta dineros.

Reb. Y las Coronas que llevan? y lo que traen al piscuezo?

Jos. Eso es un pruigio, Rebeca, yo no he visto Caballeros con más riqueza en mi vía.

Reb. ¿Y arreparaste en aquello que llevaban en las manos?

Jos. Qué habian de llevar? los frenos.

Reb. No era eso, unas caxetas, tamañas como pucheros, que parecían de oro.

Jos. Eso no lo ví: yo pienso que trairán alli las Joyas ó algun regalo muy gueno.

Reb. Y los Negrillos, Jusepe? ¿no era un regucijo el vellos con sus pasillas? los dientes $\tan$ brancos y tan parejos.

Jos. Lo que no me jizo gracia, jué ver los Alabarderos con los vigotes tan largos; en verdá, que me dió mieo.

Reb. Pus porqué?

Reb. No hay que acoldalse ya de eso.

Jos. Cómo no? jasta la muerte lo tendré en el pensamiento:

Dios me libre de sus unas. 
Suenan voces de vivas de muchachos y Misica de Clarin y I Timbales; $y$ ellos dicen con placer:

Reb. Que vienen los Extrangeros, agila por aí delantre, $y$ ansí otra vez los veremos.

Jos. Jácia la plaza de Herodes tomaron, vamos corriendo.

Vánse corriendo, $y$ suenan los vivas e instrumentos, $y$ sale Herodes despavorido.

Herod. Hacia esta parte resuenan 10 los bélicos instrumentos, que publican la osadía de los Reyes extrangeros. Quién vió orgullo tan atroz! cómo esta injuria tolero! ¿Por las calles de mi Corte, ante mi Palacio Regio, con tanta desenvoltura infamia tal? ¿ cómo puedo sufrir con tanto reposo 20 delito $\tan$ manifiesto, que inmediatamente ofende el honor de mi respeto? ¿cómo puedo estar aquí con tal quietud y sosiego, sin haber ya dado órden para que a esos Extrangeros, por traidores $\mathrm{y}$ atrevidos los arrestasen, $y$ luego les cortasen las cabezas, y sirviesen de escarmiento en mi Reyno y en el mundo? iQué afrenta para mi Cetro, en sabiendo los Monarcas inmediatos a mi Reyno, que disimulé esta injuria, que sufrí este vilipendio! ¿qué dirá de mí Octaviano al saber este suceso? ¿qué dirả el Senado todo? ¿qué dirá el Romano Imperio, quando sepa que dexé pasar tal atrevimiento? si esto no castigo, entonces podrá qualquier Reyesuelo burlarse del Rey Herodes y atropellarle su Reyno. 
80

Ea, voy a dar la órden

de que los arresten luego

sin otro examen, $y$ al punto

por traydores a mi Cetro

públicamente dividan

las cabezas de sus cuerpos,

y a mi presencia las traygan.

Suenan Clarin y Timbales.

Otra vez los Instrumentos

bélicos han resonado

10

para aumentar mi tormentó;

pues esos mismos traydores

a mi rigor dan fomento

para publicar la guerra

contra vosotros.

Suenan los mismos Instrumentos y vivas de muchachos.

¿Qué es esto?

públicas aclamaciones

$67]$

a unos Reyes extrangeros.

por mis vasallos? traydores!

20

ésta es rebelión: yo muero!

há de la Guardia! Soldados!

Centurión! Alabarderos!

nadie responde: $\sin$ vida

estoy de ver tal suceso.

Esta es trayción conocida

que mis vasallos me han hecho:

Las Guardias se han retirado,

el Palacio está en silencio,

qué he de hacer? turbado estoy,

a determinar no acierto;

todo es confusión y asombro;

daré voces? no lo apruebo:

el Pueblo está sublevado

con este Monarca nuevo,

porque será de la Estirpe

del Rey David, según pienso:

si esto es así, soy perdido,

dió fin mi Corona y Cetro:

mi destino es ya la muerte,

que por instantes espero

a la violencia de algunos,

quizá de mis gracias llenos,

porque siempre en tales casos

suelen ser los más sangrientos

aquellos que más favores 
entre todos recibieron.

Ay de mi! la tolerancia me conduxo a tal extremo;

que un Rey no ha de ser afable

con sus Vasallos: severo,

que así el temor les estorba

llegar á $\tan$ vil exceso.

De mi bondad abusaron;

mas ya no tiene remedio.

Llamaré otra vez las Guardias.

Hacen ruido de pasos.

Hacia aquí unas pasos siento.

Como turbado.

Si serán estos traidores?

yo me alisto y me prevengo.

Saca la espada.

llegad, traidores....

Salen los dos Ministros, é hincan la rodilla.

Los 2. Señor!

Herod. A qué venis? decid presto.

Los dos al verlo quedan como turbados.

Min. I. A vuestras plantas turbado teneis un humilde siervo.

Min. 2. Señor, si yo os ofendi, en vuestra mano el acero teneis, empleadlo en mí.

Her. Ya he cobrado nuevo aliento: levantad, $y$ no os turbeis:

a que veniis? decid luego.

Levántanse.

Min. 1. Señor, como vos mandasteis, que convocase a Consejo ante vuestra Magestad a los Escribas del Pueblo, Príncipes de Sacerdotes, cumplí al punto como debo vuestro Real mandato: todos obedeciendo al precepto, puntuales han venido, y siendo el órden expreso, que en el retrete esperabais, entraron en él, y viendo 
que vuestra Real Magestad

no estaba alli, recurrieron

a las Guardias, que ignorando

vuestra ausencia, respondieron,

que estabais en el retrete:

a escudriñarlo volvieron,

y no hallándoos, me avisaron

del caso, y yo discurriendo

podríais haber salido

por el escape secreto,

sin que lo notase alguno

de los Guardias, vine luego

con mi compañero aquí,

donde os hallé mas suspenso,

atónito, perturbado,

casi en el último aliento

quedé, quando así os ví airado, $y$ en vuestra mano al acero.

Herod. Para castigar a quantos son traydores a mi Cetro.

Min. I. Si en mi gustais emplearle, por leal sabreis que muero.

Min. 2. En mí teneis un esclavo, $y$ de seros fiel me precio.

Herod. Las obras crédito dan, que las palabras son viento.

Embayna la espada.

Min. I. Penetrar quisiera yo vuestros Reales pensamientos, aún aquellos más ocultos.

Herod. Ese es grande atrevimiento

Contra mi Real Magestad.

Muy airado.

Min. 1. Señor, para obedecerlos.

Herod. Decidme, si soys leal, ¿ cómo dais consentimiento, que por las plazas y calles más notorias de este Pueblo a esos tres Advenedizos, que dicen, son Reyesuelos, los aclamen mis Vasallos con alegria y contento? que los repetidos vivas en cuidado me pusieron; pues hasta en las mismas puertas de mi Palacio se dieron. 
Min. I. Aunque lo observé, Señor, lo deseché con desprecio; pues todos esos aplausos eran de pueriles ecos, que siempre la novedad más extraña aplauden ellos, como que son inocentes y no saben lo que es yerro; vuestros leales Judios no conocen otro dueño que a vuestra Real Magestad: no hay novedad en el Pueblo que os pueda causar cuidado, ni el más mínimo recelo.

Herod. Basta ya, voy al retrete, no os retirais, mientras vuelvo.

Váse, $y$ le hacen cortesta.

Los 2. El Cielo os guarde, Señor.

Min. 1. Quién vió orgullo tan sobervio que Judea haya llegado

a tan infeliz extremo! ¡que reconozca por Rey a este orgulloso extrangero $\tan$ vano, $\tan$ ambicioso, $\tan$ inhumano, $\tan$ fiero, un intruso en la nación y de baxo nacimiento! El Imperio atropellando nuestras leyes y respetos, por asalto hizo esta infamia contra Dios y contra el Reyno porque siempre las lisonjas pueden más que los decretos, y hoy se estiman estas más que los heroycos trofeos, que lo ilustre de la sangre y el noble procedimiento. Oh, si supiese Octaviano, como yo que lo presencio, del modo que este villano trata sus Reales Decretos, yo aseguro, no estaría tan pagado y satisfecho de su proceder infame. Un hombre es este que a nadie guarda su debido fuero: aquel que más fiel le sirve, 
es siempre quien hace menos:

tan desconocido, ingrato, tan desleal, tan sangriento, embidioso como él mismo, y de viles pensamientos. Oh, si el Cielo dispusiese fuera cierto el Nacimiento de ese Rey de los Judíos, que buscan los Extrangeros, y que llegase a reynar en Judea en nuestros tiempos! iqué honor para la Nación, qué quietud $y$ qué sosiego para todos, y qué día tan plaúsible en este Reyno!

Min. 2. Puede ser que el Cielo quiera darse ya por satisfecho, y tengamos hoy nacido a medida del deseo legítimo Soberano, descendiente del Excelso y Real tronco de David, que gobierne nuestro Pueblo.

Min. I. Está Dios muy ofendido de los continuos defectos de su porción escogida, no entiendas, que gozaremos en nuestros días tal gloria.

Suena caxa.

Ya viene el Rey, en tu pecho todo quanto me has oido, quede oculto en todo tiempo, que esto ha sido desahogo con un leal compañero.

Sale Herodes.

70] Los. 2. Gran Señor ...

Herod. Al Centurión

de guarnición decid luego que sin dilación alguna busque a los tres Extrangeros que por esas calles andan, y les diga que yo quiero verlos hoy en mi Palacio, que no vuelva sin traerlos.

Se hará como disponeis. 
Vánse.

Herod. Ya que supe del Consejo de los Príncipes y Escribas el lugar de Nacimiento, que es Belén, según Miqueas, quiero ver qué hombres son estos, cómo vienen y porqué así dexaron sus Pueblos, quién les llevó tal noticia, si acaso ya ha mucho tiempo: en fin con el disimulo que corresponde a mi ingenio, desentrañaré este caso, $y$ veré sus fundamentos, que puede ser, y es.muy fácil, sea todo un embeleco, $y$ si fuere realidad, todavía no me he muerto, para saber castigar infames atrevimientos.

Voy al retrete a esperar

a estos Reyes embusteros. Váse.

Fin. 
La Adoración de los $\mathbf{S}^{\text {tos }}$ Reyes a Jesu-Christo.

\section{Coloquio Quinto.}

Personas.

La Virgen con su Niño.

Herodes Rey.

Un Centurión.

San Melchor Rey Anciano. Josef Pastor.

S. Gaspar Rey Jóven. Rebeca Villana.

S. Baltasar Rey Negro. Acompañamiento. Música.

Salen los tres Reyes y Acompañamiento, precediendo Clarin 10 y Timbales.

Melc. Soberano Dios, Rey Niño, ¿a donde os encontraremos? donde teneis los Palacios? donde vuestro Nacimiento? afligido el corazón se mira con el deseo de rendir adoraciones a Vos, como digno objeto de nuestra veneración y cuidadoso respeto. ¿A donde estais? pues la Estrella, nuestra guía, no la vemos; por lo que hemos inferido, has nacido en este Pueblo: y lo que más nos contrista y la aficción que tenemos mayor, es, que preguntando por Vos, mi Dios, Niño excelso, ni dan la menor noticia, ni aún nos responden: qué es esto, Señor del Cielo y la tierra? reveladnos el Misterio. 
$\mathrm{Si}$ es vuestro Divino agrado, que así de esta suerte andemos atribulados, ansiosos, buscando nuestro remedio (que sois Vos), nos conformamos, cúmplanse vuestros Decretos.

Lleguemos por esta calle, si os parece, compañeros, a preguntar, si ha nacido en ella nuestro consuelo.

Los 2. Lleguemos, que puede ser hallen fin nuestros deseos.

Al ir a entrar los detiene el Centurión.

Cent. Señores, por vuestro honor dignaos parar $y$ atentos me oid: Mi Rey, mi Señor, a quien todo el Pueblo Hebreo rinde justo vasallaje, como a su único Supremo, el grande Herodes, me manda deciros con el respeto debido a vuestras Altezas, que os sirvais, en justo obsequio de su Excelsa Majestad, venir en mi seguimiento a verle en su Real Palacio, donde os espera, supuesto que solicitais saber del Monarca verdadero de los Judíos.

Los 3. Conformes el mandato obedecemos.

Melch. ¡Oh Rey nuevo de Judea, bien sabeis nuestros deseos! no cesarán nuestras ansias, no tendrá fín nuestro anhelo hasta hallaros, Rey Divino, hasta encontraros, consuelo de nuestras almas, pues soys, según lo afirma mi pecho ya inflamado en vuestro amor, el Rey de Reyes terrenos, a quien por justo homenaje, por debido acatamiento obliga a todos rendiros los más sumisos respetos, colocando a vuestras plantas 
su poder, Corona y Cetro.

Gasp. ¡Oh Señor, Rey el más sabio, que disponeis de esos Cielos, manifestadnos la Estrella, no retireis sus reflejos,

no oculteis de nuestra vista

la que ha de ser el más cierto término de las congojas, que ahogan hoy nuestros pechos!

Balt. ¡Oh Magestad escondida, oh Rey Supremo del Cielo, quando tendremos la dicha de adoraros $y$ ofreceros derretido el corazón en vuestro amor y respeto!

no os tardeis en que consigan nuestros suspiros su objeto.

Vánse, $y$ salen Josef $y$ Rebeca.

Jos. Sabe lo que hay, Rebeca, que en llegando a nuestro Puebro,

Maire mos dará mui fijo que cuentar y no dineros.

Reb. Pus porqué? Jusepe, dí.

Jos. Yo me sé muy bien mi cuento:

ya te he dicho rato ha, vámonos de aqui en un vuelo, que Mayre no es toa miel, y estará jecha un veneno, con razón contra nosotros, porque no hemos io presto. Vámonos por Dios, Rebeca.

Reb. No seas tan matraquero.

Jos. Pero si ya habemos visto de espacio a los Extrangeros, qué mos quea ya que ver?

Reb. El remate y paraero de estos tres Señores míos.

Jos. Mas que me voy aborriendo: camina por aí delantre, mira, que si no, te dexo.

Reb. El camino está parao; no se me da un pito de eso, Desengáñate, Jusepe, que jasta apurar el cuento, no me voy yo de la Corte. Soy coriosa, lo confieso. 
Mira dentro.

Oyes, mira, hacia el Palacio

van los Reyes jorasteros:

el Centurión va delantre

con sus cien Alabarderos.

Jos. Vaya muy enhoraguena

con sus cien pipas de cuernos;

no mientes a esos Gavachos,

porque too me estremezco.

Reb. Qué manía le has tomao

a esos probes.

Jos. Si son fieros.

El gato escaldao juye

del agua fría: les temo

como a una espaa desnua.

Mira dentro.

Reb. Oyes, ya han colao drento

del Palacio: irán a ver

al Rey Herodes: qué gueno!

agora se jarán los quatro

munchísimos cumplimientos.

Jos. Déxate de tanta prosa,

y a la Aldea vamos presto.

Reb. Reniego de tí, Jusepe,

que eres un gran majaero.

Dále un golpe $y$ vánse, y salen por otro lado los Santos Reyes solos y Herodes.

Herod. Señores, ¿qué novedad os ha traido a mi Reyno,

que me ha puesto en confusión

y me tiene muy suspenso?

Pues siempre fué estilo Real, que quando pasa un Supremo

de su Reyno a otro, avisa

con Ministros Mensajeros:

y Vos perdonad, si os diga

no que anduvisteis siniestros,

sino que os habeis entrado

en el mío como vuestro:

así me es indispensable

el más justo sentimiento;

pues si hubieseis avisado, coma es debido, en mi Reyno abundan las atenciones, la urbanidad y el respeto: 
de mí nunca se dirá, os he sido desatento.

Mas dexando ahora este asunto, supongo que vuestro Reyno

es, donde os hallais: así, como legítimos dueños, disponed lo que os agrade:

$y$ ha de merecer mi afecto, recibir un gran favor, $y$ es, que alojeis desde luego en este vuestro Palacio el tren.

Melch. Señor, no podemos, $y$ así os estimamos mucho tan cortés ofrecimiento.

Herod. ¿Pues qué motivo apresura para negarme el obsequio que os pido?

Melch. Sabed, Señor, que son juicios del Cielo los motivos que nos urgen, para no tomar asiento en vuestro Palacio Real; por ahora no podemos, y damos por recibidos los obsequiosos afectos, con que nos quereis honrar: y así perdonadnos luego, dándonos vuestro permiso, para que ansiosos búsquemos al nuevo Rey de Judea, si ha nacido en este Pueblo. Este es el solo motivo, que nos sacó de los nuestros. $\mathrm{Si}$ os agravió nuestra entrada en vuestro Judayco Reyno, sin preceder el aviso, disimulad ese yerro, pues, como quien nos movía a este viage, era el Cielo, partimos luego al instante, sin prevenir los respetos, que se deben observar entre los Reyes terrenos.

Es cierto que a un Rey buscamos del Israelítico Pueblo; pero nuestra $\mathrm{Fe}$ nos dicta, que es Rey que baxó del Cielo 
con que a un Rey de este carícter

los demás Reyes debemos

buscarle, para rendirle

adoraciones, respetos,

sin prevenirlos con otro

que solo sea terreno.

No tenemos más razones

con que poder responderos.

Herod. Con grande atención oí

vuestro decir tan discreto:

permitidme que os pregunte,

como interesado en ello;

pues teniendo en mis Dominios

tan gran dicha, tal portento,

qual es el haber nacido

un Rey que baxó del Cielo,

me es preciso inspeccionarlo,

$y$ hago en esto quanto debo.

Habeis de saber, Señores,

que esperamos con deseo

20

en nuestra Mosayca Ley

al Mesías verdadero:

el día de tanta gloria,

que al mundo viniera, es cierto

fuera para la Nación

dia grande de contento.

Como supe, que vosotros

preguntabais en mi Reyno

por el Rey recién nacido

del Israelítico Pueblo,

$y$ aquí se nos ha ocultado

tanto, tan gran Nacimiento,

como el lugar donde ha sido,

llamé al instante a consejo

a los Príncipes y Escribas

que en mi Corte sabios tengo:

les pregunté, me dixeron

lo que a ese asunto escribieron

los Profetas de Israel:

en qué Ciudad ó en qué Pueblo,

y que tiempo nacería

el Mesías verdadero.

Sin deternerse, mis Sabios

a la pregunta dixeron:

que en Belén, Ciudad antigua

de este mi Judayco Reyno

nacería el gran Mesías,

Príncipe del Pueblo Hebreo, 
que Miqueas lo decia

en su Vaticinio: luego

hice, que os llamasen, para

preguntaros por extenso,

como ahora lo practico,

$y$ en vuestra atención espero

que me habeis de responder.

Decidme, pues, ¿ en qué tiempo

salisteis de vuestras Cortes?

¿quién sirvió de mensajero

Io

para el anuncio feliz

de un tan grande Nacimiento?

Melc. Habrá, Señor, trece noches,

que estando yo en mi aposento,

al punto de recojerme

en mi acostumbrado lecho,

al mediar la noche ví

en el Cielo un gran Lucero,

una Estrella extraordinaria,

hermosa antorcha por cierto.

Al mirarla, tal influjo,

20

tal moción causó en mi pecho,

que sin poder contenerme,

mis ojos dos arroyuelos

de lágrimas arrojaron,

sin saber el móbil de esto.

Dábanme tales impulsos

de salir de mi aposento,

y empezar a caminar,

abandonando mi Reyno,

que me vencieron al fin.

Salí, pues, de mi aposento,

con designios de observar

del Astro sus movimientos:

ví según Astrologia,

no era el presente de aquellos

que en el firmamento están,

ni aún en el ínfimo Cielo.

Sosteniase en el Ayre,

casi encima de mí mesmo:

atendí que se movía,

40

quando me acercaba, a verlo:

quando paraba, paraba,

como si fuese instrumento

mi movimiento del suyo.

Esto observado, me acuerdo

por alta disposición

de una especie, que en mi Reino 
corría con grave apoyo

de los Sabios y Discretos:

esta era un Vaticinio

que un Profeta de los nuestros,

dixo en los pasados tiempos:

que nacería una Estrella

de Jacob, signo el más cierto

de haber al mundo venido

un Rey baxado del Cielo,

que reynería en Jacob,

y su Imperio sería eterno.

Con esta especie, al instante,

sin detenerme un momento,

dispuse con brevedad,

el venir en seguimiento

de la Estrella milagrosa,

dexando mi Corte y Reyno:

determiné caminar

sobre brutos tan ligeros,

que en decir, son Dromedarios,

bastantemente lo expreso.

Quando al salir de Palacio,

al ausentarme del Pueblo,

al comenzar mi camino,

miré al hermoso Lucero,

tan claro y resplandeciente,

que pudieran sus reflejos

competir con los del Sol:

alabé a Dios en sus hechos.

Empezé, en fín, mi jornada,

$y$ el Astro luciente y bello, principió tambien la suya, por el Ayre discurriendo, que como page de hacha mi camino iba sirviendo:

guiábame siempre, y yo

sin perder su seguimiento

daba a Dios mil alabanzas

por favores tan inmensos,

como a mí, vil criatura,

hacía sin merecerlos.

A pocos días llegué

con mis criados y siervos

a un valle que para mí

era el Parayso terreno,

pues en él nos avistamos

todos tres sin conocernos, 
nos saludamos, y al punto

cada qual fué refiriendo

lo mismo que habeis oido:

entonces a un propio tiempo

sentimos en nuestras almas

tal dulzura y tal contento,

que las lágrimas de gozo

de los ojos se salieron,

inflamóse el corazón

de nuevo con más deseos

de ver al Reciennacido

Príncipe de los Hebreos, a quien rendíamos gracia bendiciendo sus Decretos.

En semejantes Coloquios

llegamos a este gran Reyno

10

con toda felicidad,

pero aflige nuestro pecho

que al descubrir esta Corte

se nos ausentó el Lucero;

20

por lo que al punto inferimos,

sería este dichoso Pueblo,

como Corte de Israel,

el que alojaría dentro

al Rey Niño que buscamos.

Hemos andado inquiriendo

por esas calles a todos,

y nadie nos da razón

de este feliz nacimiento;

si acaso Vos lo sabeis,

nos dareis un gran contento,

porque nuestro corazón

desea con grande anhelo

verse con quien arrastró

lo fino de sus afectos.

Herod. Ya os he dicho que mis sabios

consultados respondieron,

que según la Profecía

de Miqueas, era cierto,

ser Belén la Corte misma

40

del Mesias verdadero:

si es el propio a quien buscais,

tendrá alli su nacimiento:

por lo qual es mi dictamen, os partais luego al momento

a Belén que está dos leguas

no distantes de este Pueblo:

allí podrais preguntar, 
si ha nacido en este tiempo

algun infante, $y$ tal vez

hallareis este portento, que conformes anunciais, mas yo bien sé por muy cierto, dareis el viage en valde, pues no es posible que en Pueblo como es Belén, hoy tan corto, de tanta pobreza lleno, haya nacido ese Rey, 10 que deciis de los Hebreos, $y$ mas trayendo su orígen de los elevados Cielos, que por tanto, más me afirmo no encontrareis tal Rey nuevo: pues si fuera ese el Mesías, no naciera tan grosero, se sabría en todo el mundo un tan grande Nacimiento, naciera en ricos Palacios, no donde carecen de ellos.

No por esto el Vaticinio de Miqueas será incierto, pues es testimonio, al que debemos grave respeto: infalible habrá de ser su puntual cumplimiento; por lo tanto, siendo hoy Belén un Pueblo pequeño, no es proporcionada Corte del Mesías verdadero: habrá de verificarse en los siglos venideros el Oráculo Divino, quando este Belén estrecho se amplíe para poder cortejar a un Rey del Cielo; $y$ así infiero no es ahora entendido el cumplimiento de la letra de Miqueas; pero vuestros fundamentos los teneis por infalibles, en atención al exceso prodigioso de esa Estrella, no quiero más deteneros: idos en paz a Belén, $y$ rendidamente os ruego, que al instante que le halleis, 
me deis aviso el más cierto

y puntual, para que

vaya tambien como debo,

imitándoos, a besarle

los piés y a reconocerlo

por legítimo Señor

mío y de todo mi Reyno.

Melch. Pues dando vuestra licencia,

a Belén nos partiremos,

y mandad hasta otra vez.

10

Dios os guarde:

Herod. El alto Cielo

77]

os acompañe, os dirija,

y hallen fin vuestros deseos.

Vainse los tres Santos, y queda Herodes por un rato como suspenso.

Her. ¿A un Rey buscando venimos, que ha nacido en este Reyno, porque en el Oriente vimos

un portentoso Lucero,

que claramente nos dixo

su importante Nacimiento?

Qué es esto que por mí pasa?

qué es esto, Herodes, qué es esto?

¿venir buscando otro Rey,

teniendo en la mano el Cetro?

cómo has sufrido esta injuria?

¿Cómo tal atrevimiento,

pacífico has tolerado,

atropellando el respeto

que a tu presencia se debe?

Qué es esto, Cielos, qué es esto?

¿oir mi propia deshonra

y estar con tanto sosiego,

sin haber executado

el castigo más severo qual merecen estos hombres

por su infame atrevimiento?

pero, ay de mí! ¿si serán

avisos del alto Cielo,

para que yo me retire

de este Reyno que poseo

con mala fe? puede ser;

pero yo así no lo entiendo;

no son piadosos avisos,

sino castigos tremendos

para injusto usurpador 
del Israelítico Cetro,

que no es anexo a mi sangre,

pues yo no soy heredero

de la Casa de David;

ni tampoco soy Hebreo,

aunque esté circuncidado,

Así pretendeis, o Cielos, castigarme? pues sabed, que a nadie, a nadie le temo.

No he de consentir que otro,

viviendo yo, tenga el Cetro

de Judea, porque yo

sé gobernar bien mi Reyno:

si alguno aílo pensare,

es vano su pensamiento.

Luego que reciba aviso

de los Reyes extrangeros,

pasaré a Belén, veré

quién es este Infante nuevo

Rey de Judea, mal dixe,

20

este atrevido grosero,

que intenta vil destronarme,

y a pesar del mundo entero

be de beber de su sangre.

.Aunque se opongan los Cielos:

a pesar del Cielo mismo

lo he de perder... (qué profierol),

a pesar del Cielo dixe?

mal dixe, que no es mi intento

oponerme contra quien

probar mi espada no puedo.

Pero si encuentro al Infante, si a este rapacillo encuentro, le daré a entender muy bien que yo solo soy Supremo

Rey de Judea, y no otro,

aunque no sea heredero

de la Casa de David,

ni que haya nacido Hebreo,

que eso es de poca importancia,

si al fin hoy manejo el Cetro;

esto solo es suficiente

para consentir primero

perder mil veces la vida,

que soltar lo que poseo.

En fin a Belén iré,

no como esos necios fueron

a rendirle adoraciones, 
sino a rendirlo a mi acero:

la vida le he de quitar, pésele a sus padres mesmos, y si acaso lo resisten, haré lo propio con ellos; no ha de reynar en Judea. si no es yo, que estoy viviendo, en muriendo, más que reyne aunque sea el mismo Infierno. Ha de la Guardia?

\section{Cent. Señor!}

\section{Sale el Centurión}

Herod. Tén cuidado, si de esos

Seflores, que aquí han estado

viniese algun mensajero,

de avisarme luego al punto.

Cent. Obedeceré el precepto.

Vduse cada uno por su lado, y salen los tres Santos Reyes, y la Estrella al Pafio.

Melcb. Bendito seas, a Dios! por tan santas Providencias, que así cuidais de nosotros, como semejanzas vuestras: ya nos disteis el consuelo, que viésemos nuestra Estrella, quitándonos el pesar que tuvimos en su ausencia.

Gasp. Demos a Dios sin cesar por su inefable Clemencia, mil gracias, pues se dignó desterrar la gran tristeza que oprimia nuestras almas, presentándonos la Estrella, índice que nos explica sus piedades tan inmensas.

Balt. Ya respira el corazón

júbilos y complacencias, porque vieron nuestros ojos la luz que ha de ser maestra que nos enseffe otra luz, que ilumine las potencias, de nuestras almas, $y$ así no caminarán a ciegas.

Melch, Ya estamos en el camino, gracias a Dios, ya la Estrella se nos ha manifestado, 
$y$ nos dice, aunque sin lengua, que montemos en los brutos, y con toda diligencia partamos para Belén: nunca es buena la pereza, y más en cosas que tocan

a la Deydad Sempiterna.

Vámonos, pues, si os parece

a seguir nuestra carrera.

Cos 2. Tus cuidados son los nuestros, lo que quisieres, ordena, que pronto te obedecemos.

Melch. Adelante nos esperan los demás criados, vamos a Belén, que es la más bella Corte que en el mundo hay, pues tan gran Monarca encierra.

Vánse, y salen por otro lado Josef y Rebeca, esta llorando con un lienso a los ojos.

80] Jos. No te lo ixe, Zagala,

si tomarás los consejos

que siempre te da tu helmano,

no te socediera eso, Acuéldate, que en la Corte te lo avisé, $y$ en efleuto no jiciste nengun caso; pus tómate estos bufiuelos, que te ha regalao Mayro con la tranca, por lo mesmo no quería detenerme

en la Corte ni un mimento.

Con Mayre no partas peras, porque ya sabes su engenio; y sobre too, los jijos debemos estar atentos a lo que mandan los Payres, para al punto obedecellos, porque ansí lo manda Dios en el quarto Mandamiento.

Reb. Mijor Consejero jaces que pastor de los carneros.

Jos. Oyes, y que no es mentira. Sende que ví aquel protento, $y$ lo aoré en el Portal Dios y Hombre en un mesmo tiempo, sé más de quatro cosillas, $y$ tal que me las apuesto 
aunque sea con los dotos

Rabinos del Santo Tempro, porque el Niño aquella noche me limó el entendimiento. ¿Pus qué, digo, es poco llance ver nacío a un Dios Eterno?

Reb. Agora que lo has mentao, me has de rematar el cuento que empezastes a dicirme, y mos lo estorvó el Lucero aquel del jopo tan largo.

Jos. Pus mira que te prevengo, tienes de estar muy atenta.

Reb. Dílo, que te lo imprometo.

Jos. Por proste y fin de plegarias, enderezaas al Cielo, que han durao cinco mil y más años sigún pienso, allegóse de una vez aquel deseao tiempo que tanto lo percuraron los antipasaos nuestros. Ansina lo ixo el otro, yo tambien igo lo mesmo: too plazo ha de llegar a tener debío efleuto. Por último, si el calletre no se trabuca en el cuento, oirás el mayor pruigio que ha pasao en nuestros tiempos, en que mos jallamos yo, Jacob é Isaac, que no miento, si digo que semos toos machuchos, limpios y guenos, de concencia muy prulija, que no gastamos enreos, patranas, ni pataratas:

y jué, que estando en el cerro velando nuestras vegilias, descorios del sucesio, mos dió gana de unas migas, por calentarmos, que el yelo ya mos tenia abrumaos, teritando sin consuelo.

Al tiempo que percuraba la sartén, dornillo y cuerno, ví de impruviso tirarse casi encima de mi mesmo, 
como si adree lo jiciera,

un Alimaña ... (ya el mieo

no me exa echar la jabra,

porque too me estremezco)

vi bajar un tromontorio

de repúsculos y fuego,

que parecía la fragua

de un machacaor de jierro.

$V_{1}^{\prime}$ echarse ... ¿ no has reparao

descolgarse sende el Cielo

alguna vez el Halcbn

$\dot{o}$ al Agnilucho ligero

a pillar al pajarillo

$\dot{0}$ al descoriao cordero?

pus lo mesmo ví baxar

sende el Ayre ó sendo el Cielo

un Pajarraco encendio,

como cojete rastrero,

arrojando tantas chispas,

que pensé que too el pelo

se me chamuscaba estonces;

pero, y qué, si enmedio de esto

era un Zagalón jermoso,

branco y rubio: qué bien jecho!

qué entallao! qué pulio!

qué garvoso! qué perfleuto!

la cara de leche y sangre,

anacarao el piscuezo,

las manos como azucenas;

parecía a mi enteleto

un Préncipe ú Señonito,

que tiene munchos dineros:

venia $\tan$ ornao

con tantos moños al cuello,

el pellico de candela,

el jarapies de lo mesmo,

los sajones y polaynas

eran de raso muy gueno,

su vanda de calimaco,

en las patas no me acueldo,

si eran albarcas pintaas

ó alpargatas, en efleuto, uno ú otro puo ser;

no puse codiao en ello.

Por último todo el sayo

que traía el guen Mancebo,

tan lleno de clariaes

estaba, que en el mimento 
la vista se me quitó de los jojos; qué protento!

yo igo que aquella ropa se gilvanó allá en el Cielo, pus toa era de plata ú de oro, que es lo mesmo. Ansí que ví esta Pantasma, al rancho me juí juyendo, se lo ixe a los Pastores, $y$ no querian creello: cata aquí en un menute se encajó encima de un vuelo: estonces le dió a la gente tal pataleta de mieo, que te asiguro, pensé se queaban patitiesos.

El Mozetón en el Ayre, sin estrellarse en el suelo, mos encajó su embajaa, de esta manera iciendo: No tengais mieo, Pastores, pues soy an Angel del Cielo, que no trato de engañaros, antes vengo muy de jecho

a diciros la verdá, como acostumbro en efleuto, dexando a parte andulemas, rebeses y otros enreos, agenos de mi carácter, os anuncio como cielto el mayor gozo del mundo, y es por dicillo más presto, que ha nacio jecho hombre el Jijo del Payre Eterno.

Esto es en una palabra lo que me ha arrancao a veros sende la Groria: coriao, que tan feliz Nacimiento para vosotros ha sio, porque os pongais muy contentos, 40 pus viene de mano armaa a libraros del Infierno. La señal de ser verdá quanto aquí os estoy diciendo, es, que vayais a Belén, $y$ le vereis arreguelto en pañales, y acostao en un Pisebre en el suelo, 
que allí lo puso su Mayre,

por no encontrar otro puesto

más acomoao en donde

colocallo: Sende luego

id a adoralle, Pastores,

que es un regucijo el vello.

El rematar de jabrar

y el trasponerse jué a un tiempo.

Estonces se alborotb

de tal suerte too el Cielo,

que parecía la Groria.

Válasme Dios, qué embeleso!

qué rabeles, qué guitarras!

qué sonajas, qué panderos!

qué citoras, qué cornetas!

qué pitos $\mathrm{y}$ qué isturmentos

al modo de clavicornios!

Rebeca, si pieldo el seso

cada vez que a la mimoria

se me viene aquel estruendo

que tráan, en mi vía

pienso oír mayor surréo;

parecía tabarrera,

$\delta$ quando andan los vencejos

voleteando por el ayre:

de este moo los Mancebos,

más de milenta volaban,

tocando sus isturmentos,

cantando unas coprillas

y unos corríos tan bellos,

que era capaz de encantar,

aunque juese al mundo entero.

A toa esta zalagarda

se juntaba estar el Cielo

tan lleno de clariaes,

tanta luz $y$ tanto juego,

que parecía mediodía.

Si habia alli en mi conceuto

más de setenta candiles,

más de mil velas de sebo,

un sinnúmero de jachas,

toas a la par ardiendo.

Con tal zambra ú algazara

$y$ too este encendimiento,

espaventaas las ovejas

$y$ los carneros juyeron

a reportarse en el valle:

jasta el burro con el mieo 
104

ú la alegría, queó

como tonto, boquiabierto,

que mirao a guena luz,

no era el causo para menos:

del mesmo moo queamos

ansí los tres compañeros,

y más quando arreparamos

que al son de los isturmentos

cantaron un villancico,

y dempues lo repitieron,

otras munchisimas veces;

y jué, si mal no me acueldo,

por ser una algarabia,

que nenguno la entendieron,

sino el Rabaán Isacio:

Groria en acelgas fideo

se entierra paja en ombligo,

que en lengua crara es lo mesmo

que dicir: En las alturas

a Dios la Groria cantemos,

$y$ en la tierra paz al hombre, con agrao y guen afleuto.

Viendo, pus, el Rabaán, que too el monte era un Cielo, mos dixo a toos: Arriba,

vamos a ver tal protento, que esto parece verdá, no hay pauto, ni encantamento.

Estonces toa la gente se previno de panderos, castanletas y sonajas,

$y$ yo por ser el prostero,

me agarré con la zambomba,

Partimos toos contentos

por aquel campo baylando

al son de los isturmentos.

Llegamos por fin al sitio

que era un probe portalejo,

a espaldas de la Ciá,

medio caío en el suelo;

quando toos reparamos,

que alli estaba todo el Cielo,

alli estaba todo el Sol

y toitos los Lluceros,

las Estrellas y la Luna,

jasta el Llucero miguero.

Estaba tan rellucio

el gueno del portalejo, 
que estornué por tres veces.

$\mathbf{I}$

Reb. $-\bar{Y}$ se puee creer eso?

Jos. Mira no te dé un sopapo, pus qué yo soo embustero?

¿'si estaba allí el Sol Divino, y lo miré muy atento, no había de estornuar?

Reb. Con ese hueso a otro perro, ¿qué me quieres tú encajar, que mirastes al Sol mesmo al punto de media noche? esa mentira no creo.

Jos. No es, tonta, ese Sol que piensas, que el que te voy referiendo, es Sol más resplandeciente, que es el Ninlo Dios Eterno:

Este es el grande Masías, que dicía nuestro Abuelo.

Reb. Ja caygo, sigue la historia.

Jos. Pus como iba iciendo, ansí que vie yo al Niño $\tan$ bonito como un Cielo, too me queé pasmao: si vieras que lindo pelo tenía tan collorao, y sus jojos dos Lluceros. La brancura de su cara era de nieve, no miento, en la boca no me paro, porque too me embeleso, quando me acueldo de ella. Era too tan perfleuto, tan pintao, y tan jermoso, como baxao del Cielo, y lo que más me aquelló, jué, que siendo $\tan$ pequeño, a toos tres mos miraba como un mozetón ya jecho.

Estaba allí acostao en un Pisebre en el suelo, envolvio en sus pañales, y a su lao miré atento a su Mayre tan jermosa, como que parib aquel Cielo, estaba mirando al Niño con unos jojos may tiernos, $y$ al otro lao su Esposo estaba muy circuspleuto, 
tambien miraba al Choquito.

Reb. $Y$ ese hombre era muy viejo?

Jos. Era un hombre rigular, de treinta aflos y medio.

Reb. Era su Payre del Niño?

Jos. ¿Si es Jijo del Payre Eterno, había de tener dos Payres?

Reb. Pus no dices, majaero, que era Esposo de la Mayre?

Jos. Jesús, y que apretaero; es su Payre putativo, porque su Payre perfleuto está en la Groria, que es Dios, como te tengo sopuesto.

Su Mayre es virgen, porque obra alguna de Varón, ni aún de su Mario mesmo.

Reb. ¿Conque en fin, este Choquito es Jijo del Payre Eterno?

Jos. El mesmo es, Rebequilla, se ha descolgao del Cielo, viene a pagar muestras culpas y aquel pecao primero.

Reb. Pus qué es deudor este Niño?

Jos. Es deudor al Payre Eterno, porque como Adán pecó, en querer ser como el Verbo, pus quixo ser doto y sabio, como lo era Dios mesmo; y ya sabes que Dios Jijo es el Propio Entendimiento, por eso ha nacio Hombre el Jijo de Dios Inmenso, para pagar con su Vía aquel pecao primero, que jué de Sabiduría, y tambien de yerros nuestros, no porque este Niño Dios jué agresor en el mal jecho, sino porque mos estima como a jijos verdaeros, y porque tambien veía que nadie en el mundo entero podia satisfacer por el pecao primero, sino su Inmensa Grandeza, por ser el pecao inmenso. 
No preguntes otra cosa, arremataré mi cuento.

Reb. Prosigue, que va may lindo.

Jos. Estaban tambien adrento calentando el Chicorrito con su baxío un Guey nuevo y una Mula respingona, que aunque brutos, conocieron a este Niño por su Dios, su Criador y su Dueño. Ansina que yo y mi gente vimos too el Nacimiento, soltamos nuestros pellicos y armamos alli un jopeo, como que estaba allí Dios, mira tú si era gueno. Rendios ya de baylar, mos tiramos en el suelo con las roillas jincaas, y aoramos con respeuto 20 al Niño: estonces su Mayre, con un rostro muy moesto, mos dixo: Guenos Pastores, bien conozco vuestro afleuto tan limpio de polvo y paja, en pago dél os prometo que mi Jijo os mirará como a jijos verdaeros, os colmará de su gracia, que es el más siguro medio para gozalle en la Groria, $y$ alli toos mos veremos. No olvideis en vuestras almas que este Dios con tanto afleuto, quando nacib, se acoldó de vosotros los primeros; coriao no le ofendais, que os quiere con grande extremo.

Dicho esto, yo y mi gente mos levantamos del suelo, mos despeimos del Niffo, toos llorando y gimiendo, tambien de su bella Mayre, y de su Marío mesmo: mos venimos al Ganao, y lo topamos paciendo: estonces el Rabaán me mandó encendiese juego, 
lo jice, y mos arrimamos

a calentar nuestros cuelpos, que las almas ya venían en otro mijor ardiendo.

Allí ixo caa qual

lo que sentía en si mesmo,

en haber visto el Choquito;

yo les dixe: compafieros,

en mí siento, y no es mentira,

una allegría, un contento,

que no lo pueo expricar;

siento tambien un despego

a las cosas de este mundo, que os asiguro, y es cierto tomara el echarme un saco y soplarme en el Carmelo.

Reb. ¡Ay que Santurrón está
el yueno del Zagalejo!

Jos. Pus mira ¿quieres creer que no peco de provecho?

Reb. Yo lo arreparo, ojalá

te mantenga Dios tan gueno:

y díme, hombre, una cosa, que no has mentao en el cuento, ¿cómo se llama la Mayre que parió este Niño bello?

Jos. Qué no lo sabes? María.

Reb. Y su Mario?

Jos. Jusepo, como yo, que es mi tocayo,

Reb. Es del campo?

Jos. No, que es

Maestro de Carpintero;

pero aunque probe, diescende

de lo más mijor del Puebro:

sus Aguielos jueron Reyes,

y Plofetas tambien creo.

Sabes quién es esa Gente?

los que a la montaña jueron

allá los días atrás, quando se armó aquel festejo entre la gente del campo.

Reb. Aquellos son? ya me acueldo, la hermosa Nazarenita y su Marío! me juelgo, porque sende que los ví, los quise con grande extremo. 
Tenía aquella Señora unos jojos muy moestos y une carita de Santa, con su jabrar alagüeffo. Oyes, Jusepe, no ves?

Miran al patio, donde se dexa ver la Estrella que va caminando.

por ai viene el Llucero

y tambien vienen los Magros,

y qual corren los Cigueños!

10

por porquito alli un Negrillo,

si no se tiene tieso,

se apea por las jorejas.

A donde irán tan corriendo?

pus mira, que ya pararon.

Jusepe, vamos a vellos.

Jos. Ya guelven a caminar

tan súpitos como un trueno

jácia Belén: tengan cuenta,

si no, van al Portalejo

a aorar al Niño Dios:

que me maten, si no es cierto.

Dáte priesa, Rebequilla,

$y$ así too lo veremos.

Vanse corriendo, y suena Clarin y Timbales.

Mús. No busqueis en la Ciudad

al Rey del Cielo y la Tierra,

que como viene a enseñar

ame el mundo la pobreza,

en un Portal derribado

su Corona y Cetro ostenta.

Salen los tres Santos Reyes y Acompanamiento, la Estrella al panto rodeando, y ellos siguiendola con mucha atencion.

Melch. Qué misterio será éste?

pues no ha querido la Estrella, entremos en la Ciudad.

¿A donde irá su carrera rodeando las murallas?

sigámosla sin perderla

de nuestra vista, pues ya

40

se va acercando a la tierra,

ya está encima de nosotros. 
Ird haciendo la Estrella lo que dicen los versos. I

ya apunta sobre una cueva, que alli se mira en el hueco de aquella tan grande piedra. Acerquémonos, pues ya se ha incluido toda ella en la gruta: Cielos altos! grande Misterio esto encierra. Lleguemos, pues, compafferos, entremos en esta cueva, por indagar los Arcanos de esta prodigiosa Estrella.

Asomase San Melchor por medio, y los demas se acercan, y dice la Virgen dentro:

Mar. ¿Qué curiosidad os mueve a registrar tal pobreza?

Melc. ¿Sabeis, Señora, en qué parte ha nacido en esta tierra un Niño muy prodigioso, que todo el mundo desea, 'Monarca de los Judios, $y$ nuestra fe le venera por Criador Sobrano

87] de los Cielos y la tierra?

Mar. Eso lo deben saber los Magnates de Judea.

Sale San Melchor afuera, y vuelve a mirar a la Estrella, que estara firme sobre el Portal.

Mel. Oh Señor Dios, el más Sabio! ¿a donde irán nuestras huellas a buscarte? pues Herodes nos afirma, que un Profeta dixo, que en Belén había de nacer vuestra Clemencia: tambien afirma lo mismo esta milagrosa Estrella, pues aquí nos ha traido y aquí está inmutable y queda, $y$ aún sus luces todas juntas entran en esta caberna. ¡Oh, válgame Dios, Señor, sacadnos de tanta penal Lleguemos, pues, otra vez, que si esta Señora niega, tendrá sus justos motivos, 
y si el Rey nace en pobreza,

trazas tiene esta Señora, según su rostro lo muestra, tan modesto y $\tan$ hermoso, de ser una Madre Reyna. Preguntémosla otra vez, que tiene señales ciertas de ser Madre del Infante. que ver nuestro amor desea.

Entra en la cueva que se descubre un poco mas.

Sabed, hermosa Señora, que venimos de lexas tierras, rompiendo incomodidades del tiempo y sus inclemencias, buscando a este Dios Infante, que ha nacido de Judea Rey, la guía que el Cielo nos dió, claramente muestra, está aquí al que buscamos. ¿Hacednos, pues, la obra buena 20 de decirnos (porque cesen de una vez las ansias nuestras) si teneis algunos hijos?

Mar. Uno tengo.

Melch. ¿Y es de tierna edad ese vuestro Hijo?

Mar. Trece noches ha que en esta pobre cueva le dí a luz.

Melch. Pues dignese vuestra Alteza, de mostrarnos ese Infante, y perdone la molestia.

Mar. Sí haré, porque miro en Vos ya cumplidas a la letra diferentes Profecias.

Acdbase de descubrir el Portal, toma la Virgen el Nino, que lo tendrd oculto en el Pesebre, y lo pone en sus brazos manzfiesto, estard la Virgen sentada enmedio del Portal, y la Estrella se coloca sobre su Cabeza, seflalando al Nino: los tres Reyes $y$ acompanamiento se postran, rinden las Coronas, Turbantes y Alabardas con mucha sumision.

Los 3. Este, dichosa Princesa, es el Niño Prodigioso, que nos -anunció la Estrella.

Mús. Las Primicias de las Gentes, como basas de la Iglesia, hoy se ofrecen a Dios Niño, 
Todos se levantan admirados, y queda San Melchor postrado.

Melch. Oh Dulcísimo Jesus!

muy bien venido a la tierra

seais, para remediar

todas las dolencias nuestras:

ojalá que los mortales,

a quien tanto amor ostentas, sepamos agradecer

y estimar tan gran fineza;

y vos, Cándida Azucena,

Sex̃ora la más dichosa

del Orbe, casta Doncella,

que tan gran fruto nos disteis,

Vírgen, Madre, clara Estrella,

Bendita soys entre todas

las Mugeres de la tierra.

Recibid la voluntad

de los tres, que no es pequeña,

en Sacrificio, y que supla

a lo corto de la ofrenda.

Este Oro que producen

Abre la caxa y lo manifesta

las entranas de la tierra, más ardiente que el Sol mismo.

Tributo debido sea

a su Sacra Magestad,

Rey del Cielo y de la Tierra.

$Y$ perdonad, Gran Señora,

mi cortetad, que quisiera

ofrecer a vuestro Hijo

un don digno a su Grandeza.

Pone la Caxita de Oro a los pies del Ninto, los besa, levaintase $y$ se retira a un lado.

Gaspar postrado:

Oh Dios de la Magestad,

Criador del Cielo y. Tierra,

Omnipotente Señor, la más superior fineza, que entre todas generosa 
hizo vuestra Providencia,

Humanándose (qué prodigio!)

para elevar (qué grandezal)

nuestra frágil, inconstante

humana Naturaleza.

Yo os adoro $y$ reverencio

por tantas magnificencias,

como vuestra diestra mano

hace al polvo de la tierra.

¡Con qué esmero, oh Sto. Dios,

10

nos llamó vuestra Clemencia!

¡quién supiera agradecer

de vuestro amor tal fineza!

Señora, iqué dignidad

teneis de tanta excelencia!

pues soys Madre de ese Dios,

mi respeto os reverencia, como Templo, como Altar

en donde mi Dios se ostenta:

y asi a vuestros piés postrado

consagro humilde esta ofrenda.

Echa incienso en un turibulo, inciensa al Nirio tres veces.

Pastillas son de la Arabia

el don que mi amor presenta,

para que por mi a este Niño

Dios perfume vuestra Alteza.

Pone la Naveta a los piés del Nino, los besa, y se retira.

Baltasar postrado:

Y yo, Señora, aunque indigno

de estar en vuestra presencia,

y la de ese Dios Humano,

que en vuestros brazos venera

mi respeto el más rendido,

os hago humilde esta ofrenda

de Myrra, para que Vos

en Sacrificio la ofrezcas

a vuestro $\mathrm{Hijo}$ por mi.

\section{Presenta la Caxita.}

$\mathrm{Su}$ virtud solo se muestra

en el Sepulcro, y así

conservadla, retenedla,

para en pagando este Niffo

como que es mortal, la deuda

que al fin pagan los que visten

la Humana Naturaleza. 
$Y$ perdonad, Gran Sefiora,

la cortedad.

Rogad por mí a vuestro Hijo,

no me aparte de su Diestra.

Pone la Caxita a los pies del Nitio, los besa, y se retira 5 como los demas.

Mar. Reconocidos, Señores, obligada a vuestra Sierva

dexais con tanta merced:

lo que mi alma quisiera,

10

fuera tener un Palacio

en que obsequiaros pudiera;

pero mi Hijo y Señor

ha escogido la pobreza

90]

para nacer en el mundo.

Infinitas veces sean

benditos sus altos Juicios:

el consuelo que me queda,

es, que de Vos se acordó,

y llamó su Providencia

para que le veneraseis

por Dios del Cielo y la Tierra,

de la Bienaventuranza

que a todos tres os espera.

Melch. No nos olvideis, Señora,

desde hoy por vuestra cuenta

corremos con la esperanza

de que nuestra vida sea

como de hombres que han tenido

tal dicha como la nuestra.

Y Vos, Divino Señor,

que tan Humano te muestras,

dirigid nuestras potencias.

Los 3. para que a gozar lleguemos

de Vos en la Gloria eterna.

Cierrase el Portal, y vánse.

Mús. A Jesús sin cesar alabemos

Con cánticos dulces é hymnos acordes,

Alabemos su gloria en lo alto,

La paz en la tierra a favor de los hombres. 40

Fin. 
La Presentación de Ntro Señor Jesu-Christo en el Templo.

\section{Coloquio Sexto. \\ Personas.}

La Virgen con su Niño.

San Josef con dos Tórtolas.

Josef Pastor.

Rebeca Villana.

San Simeón Anciano.

Ana Viuda Profetiza.

Isaac Rabadán.

San Gabriel Arcángel.

Jacob Pastor.

Música.

10

Mús. La más fragrante Azucena

que produjo Nazaret,

viene a demostrar al Templo

su perfecta candidez.

No viene a purificarse

esta Vara de Jesé,

porque siempre ha sido pura, aún en su primero Ser,

92] sólo viene por cumplir con las Leyes de Moysés, y trae a Dios por presente el mejor Pán de Belén.

Salen Josef y Rebeca con un lio de ropa, como que va a labar.

Jos. Rebeca, qué Prucisión!

es mentira que en la Groria

esta jiesta la jacieran,

tan llocia y tan jermosa:

ea, que estó atordio;

has visto, $y$ quantas farolas!

Reb. Quél más de millenta iban,

por poco me queo boba:

ésta es cosa de pruigio: 
Jusepe, estó como tonta;

qué mozetones tán bellos,

brancos, rubios como rosas,

y pegaban espejaas

con la cara y con la ropa,

que las niffas de los jojos

me jaciban cucamonas,

$y$ aún tal me relampoguean

que no me veo a mi propia.

Traza llevaban de ser

10

Angelotes de la Groria,

por los munchos relumbrios

que de sus cuelpos arrojan.

A donde se endilgarán?

Jos. Ello, el camino que toman, es para Jirusalén.

Reb. Jácia el Tempro me se antoja que irán, por purificarse

de su parto la Señora,

pus el Esposo llevaba

en una cosa reonda,

como jaula, unos pichones,

ú tórtolas.

Jos. Cachiporra!

que tú has discorrio al causo;

porque ahora jago mimoria,

sigún el tiempo ha pasao

de la Parición Groriosa

de esta Sagraa Doncella,

Mayre de Jesús jermosa,

que boy jace la quarantena.

Joraemos por la troya,

y ansí poemos llegar

más presto al Tempro.

Reb. Y la ropa?

Jos. Exala para mañana.

Reb. No puee ser: ésta es otra,

¿y si Mayre mos regana

u mos sacúe?

Jos. Qué importa:

¿será la primera vez,

que porque quiere se enoja

y mos pega con la tranca,

ú lo primero que topa?

¿y qué jaremos con eso,

dempues no mos da la torta?

arrecógete las maguas

y agila por aí, tonta. 
Reb. Es que yo, lo que dicía, era labar muestra ropa, tendella y almionalla, que lo jago en media hora, con eso jueramos limpios a ver toas esas cosas; pues es feo el presentarse en el Templo de esta forma, ansí con el jato sucio, y más siendo esta Señora, que te conoce, tán limpia, aseá $y$ primorosa.

Jos. Parece chanza si es? sende la primera hora, (qué igo?), sende el istante, que se concibió esta Rosa, jué tan pura $y$ aseá, jué $\tan$ limpia $y$ tan jermosa, que el Pecao Original no la tocó ni aún por sombra; pus la gracia de antemano, como el agua que arrebosa en un jarro que está lleno, ansí colmó a esta Sentora, de tal modo, que la culpa no prendió en tan rica joya del pecho del mesmo Dios. Es por esto tan preciosa, tan llocía, tan perfleuta, sobre too, $y$ tan graciosa, que no hubo, hay ni habrá otra moger tan dichosa.

Reb. Pues por lo mesmo debemos no llevar sucia la ropa.

Vamos de un vuelo al arroyo, $y$ en un vesible en la poza, labaré estos quatro trapos.

Jos. Y yo me pondré a la sombra

a coserme este zamarro, mientras tú lapas la ropa.

Vänse, y a la segunda siguiente copla salen la Virgen con su Nino, y San Josef con dos Tortolas o Pichones.

Mús. Ya sale la Aurora con el Sol Divino del Establo al Templo, siendo el Templo mismo. 
Despues de quarenta

dias que ha cumplido, por guardar las Leyes presenta a su Hijo.

La Ofrenda que trae es un tierno Niño, que a su Eterno Padre mucho ha complacido.

La misma pureza

que apura al Sol mismo, humilde en sus Aras ofrece a Dios vivo.

S. Jos. Purísima Esposa mia, impresos traigo en mi alma los pasos que habeis andado pisando yelos y escarcha. Yo quisiera, si os parece, que algun reposo tomaras, antes de entrar en el Templo, porque os miro fatigada con el cansancio y el frío.

Mar. No, Josef, no estoy cansada, que nuestro Dueño piadoso cuyda de su humilde esclava: lo que nos conviene ahora, es, el entrar en la Casa de nuestro Dios, porque así a su Magestad agrada.

S. Jos. Pues entremos, que annque indigno seguiré vuestras pisadas.

Describrese un Altar, y se postran los dos.

Mús. Derretido está el Amor en los brazos de su Amada, porque como es su Paloma, con sus arrullos descansa. No acierta a dexarla un punto que sin ella no se halla pues lo fino del querer de su Real Solio le arrastra.

Mar. Altísimo Padre Eterno!

Dueño, Señor y Dios mio!

Festivo día el presente para la tierra y Empireo, en que a vuestro Santo Templo trayga $y$ ofrezca a mi Hijo: de vuestra Divinidad es el Tesoro escondido. 
Tanta oblación os empeña

a franquear beneficios

a todo el linage humano; pues por él solo ha venido desde vuestra Eterna Diestra

a salvarle compasivo,

y por lo mucho que ofrezco, esta cortetad os pido.

Atended, Padre y Señor,

que vuestro Unico Hijo,

10

engendrado en mis entraffas,

si es vuestro, tambien es mio,

que si me le disteis por Dios,

Hombre y Dios os le he traido:

mirad, Señor, que la alhaja

es de valor infinito.

Vuelvo a vuestro Templo rica,

que antes pobre había salido:

eternamente mi alma

os magnifica, Dios mio,

porque vuestra Diestra Mano

tan liberal fué conmigo.

Sale Simeón y Ana buscando al Nino.

Sim. A dónde estais, Gran Señor?

a dónde estajs, cara Prenda?

Dios de Israel Humanado,

que mi alma ya deshace

en júbilos, fiel me anuncia

habeis venido a la tierra

a redimir nuestras almas

de las continuas miserias,

en que el áspid infernal

a todos tiene sugetas.

Mira al nino.

Venid, Seffor, a mis brazos, pues me hicisteis la promesa

de dilatarme los días, hasta que mis ojos vieran

lo que ahora están mirando:

mi alma en gozos se anega.

Arrodillase.

Bendito seais, Dios mio,

Bendita vuestra Clemencia, con que me favoreceis, siendo polvo de la tierra: 
¡con qué he de pagar, Señor,

de tanto amor la fineza!

dádmele acá, Gran Señora,

dádmele, Sagrada Reyna.

Da la Virgen el Niño.

Que aunque indigno Siervo suyo,

quiere este Niño le ofrezca

en mis brazos, como en Ara,

de la Suprema Excelencia,

de su Padre Omnipotente,

10

Criador del Cielo y Tierra.

Tendrá el Nino elevado un rato, mientras toca la Muisica, y en acabando le baxa hacia el pecho, y con ternura le dird:

Sim. Venga ya, mi Dios, la muerte, que es justo se me conceda

el descanso de mi alma,

según vuestra gran promesa;

pues ya mis dichosos ojos

han visto sobre la tierra

vuestra Deydad Humanada:

en exercicio ya puesta

la salvación de los hombres:

pues vuestra Piedad inmensa

ha venido a redimirlos,

porque ninguno perezca.

La luz vieron ya mis ojos,

Guía de las gentes ciegas,

de la Plebe de Israel

su Gloria la más excelsa:

en fin lograron el ver

lo que los Santos Profetas

de nuestra Ley, Patriarcas,

Reyes y noble Ascendencia

de mi Jesús no pudieron:

benditos mil veces sean

vuestros sagrados Arcanos:

quién, Dueño mio, pudiera

daros incesantes gracias

por mercedes tan inmensas.

Acercaos, Muger dichosa,

a ver la mayor fineza

de nuestro Dios, con que ensalza

Ia humana Naturaleza. 
Ana arrodillada,

Ana. Dios de Israel, Dueño mio, ¡quién este día tuviera un espíritu sublime

de Aladas Inteligencias,

para alabar sin cesar

de vuestro Amor la Grandeza!

mi corazón anegado

en sumo gozo, no acierta

a dar las debidas gracias

10

a vuestra grande Clemencia,

por tan altos beneficios,

como hoy a vuestra Sierva

habeis hecho, siendo indigno

de estar en vuestra presencia.

Leván tanse todos, y dice Simeon a la Virgen:

Sim. Atended, Madre y Señora,

advertid, Sacra Princesa,

que este Niño que os entrego

nacido de vuestra Alteza.

20

ha venido a remediar

de este mundo las miserias

de muchos, y a confundir

las mal fundadas sobervias

de los altivos y vanos:

será el blanco en que la fiera

sacrílega emulación

emplee todas sus fuerzas,

haciéndole padecer

tormentos, dolores, penas,

30

hasta darle muerte, entonces

traspasara la agudeza

de una espada vuestra alma

al ver puesto en tanta guerra

a vuestro Hijo y Sefor,

siendo la misma Inocencia.

Da a la Virgen el Nino, que lo recibe arrodillaaa, $y$ hace que llora.

Mưs. En los dulces brazos

de nuestra Princesa,

como en el Altar

nuestro Dios se ostenta.

Rendido de amor

del hombre, las deudas

se ofrece a pagar

su Santa Inocencia. 
Su vida promete darla en recompensa, por lo que merece deuda tan inmensa.

Su Padre recibe esta digna ofrenda, y queda obligado Jesús a la pena.

Por tanto alabemos

a Dios en la tierra, pues hoy por el hombre muestra tal fineza.

Mar. Hijo de mi corazón, ¡cómo es capaz, Vida mia, que viva yo en ese día de la humana Redención! si solo la anunciación del martyrio atroz y fuerte, que os espera, de tal suerte mi corazón penetró, ¡qué será en llegando yo a ver tan tirana Muerte! ¡Cómo he de poder sufrir tan duro y cruel tormento, quando me falta el aliento de solo a este Justo oir decir, que habejs de morir de dolores traspasado: quisiera, Dueño adorado, me concediese la muerte, antes que lleguen a verte mis ojos tan mal tratado.

No sé yo contradecir tan alta disposición, mas quisiera el corazón, por no llegar a sentir el veros así morir, que otro modo dispusieseis, con que al mundo redimieseis, que no fuese $\tan$ cruento, $\delta$ que tan atroz tormento para mí sola lo hicieseis.

Levántase.

Mús. Madre Purísima, Paloma cándida, de vuestros ojos cesen las lágrimas. 
Resignaos, Reyna, quie es de mi agrado ser por los hombres crucificado.

Mi Padre quiere que en tal trabajo mi Compañera seais al lado.

Yo soy gustoso, $y$ alegre pago 10 por mis hechuras lo que adeudaron.

Mientras canta la Mísica los versos antecedentes, Simeón delante del Altar repartirá velas, primero a la Virgen, despues a Ana, y a San Josef, y quedandose con otra, forman Procesión, en que presida la Virgen y a su lado Ana, delante San Josef, y a su izquerda Simeón, con pausa dando vuelta durante la Muisica, y razonamiento de los Pastores, que entre cortinas ven la Procesión, $y$ al concluir la Música dicen lo siguiente:

Reb. Si te hobieras descoriao! por poco la vemos toa.

Jos. Ajuera, ajuera, que cuelo: agarra el pellico, tonta, apeñuscate conmigo.

Jául qué Prucisión de Groria! has visto más candelillas?

Reb. Ea, que me guelvo loca.

Jos. Arrepara con coriao en María mi Señora, que lleva su Niño en brazos, qué ojos tiene de Paloma! qué flente de quistal fino! con una joja de rosa en toita la mexilla, que parece jamapola.

Mira al Niflo que pulio! su cara arrojando aljofar. Arrepara en la boquita, como el coral y la rosa: de oro fino es su pelito. No has mirao?

Reb. Yo estó boba de ver al Niño tan bello, y a su Mayre tan jermosa: $y$ otra cosa más, aspera, ¿tú no has jecho caso agora 
de tu tocayo Jusepe,

I

que en Nazarén jace obra

de Carpintero barata?

Jos. Ja lo he mirao, no seas tonta,

ése es un Santo Varón,

que jace munchas limosnas.

Hasta este punto dura la procesion, se entran todos, y sale

$$
\text { Josef y Rebeca. }
$$

Jos. Jesús, que me guelvo loco!

Reb. Jesús, que me guelvo loca!

Jos. Traías las castañetas?

Reb. Y parece chanza.

Jos. Toca.

Tocan y baylan, y canta Rebeca.

Reb. Jasta agora en mi vía vie la Groria.

La Señora me encanta,

Jesús me aboba.

\section{Canta Josef.}

Jos. Con los tres yo me queo,

véte tú sola, que no quiero más Mayre que a mi Señora.

Mientras cantan y baylan, estardn entre cortinas Isaac y Jacob, viéndolos, $y$ en acabando saldrán.

Isac. Guena cosa, acá perdios, buscándolos sin sosiego por toas partes, $y$ tú respingándote sin mieo.

Jos. $\mathrm{Si}$ sende que estoy liao con esa Gente me pelo por andar tras ellos, qué! si los quiero con extremo.

Isac. Lo cierto es, que te portas con mucha gracia y salero: te ixe, que te allegaras para ver si estaban guenos Jesús, María y Josef, $y$ too al revés lo has jecho; pue ya va un montón de días, que no te hemos visto el pelo, jasta que nos jué preciso dexar encargao a un deudo el ganao, y descolgarmos 
a buscarte. Qué te has jecho? donde has estao metio?

Jac. Yo ixera que aprendiendo

a músico y baylarín.

Jos. Ya sé que estariais diciendo, aquel mos las ha fuñio, pus no ha venlo al mimento. Habeis de saber, que he estao muy entretenfo viendo munchísimas cosas guenas, que han pasao sende el tiempo que estuvimos en Belén aorando aquel Protento.

98] Isac. Pues qué cosas han pasao?

Jos. Un montón, estadme atentos.

El diá que me mandastes allegase al Portalejo, al colar en él topé

a un Saquirote muy reto, que tomando al Chicorrito, sacó un cuchillo pequeño de peernal que traiba, $\mathrm{y}$ sin lástima de vello tan pulío y regracioso, lo circunció al mimento. ¡Qué pesaumbre tamana pasé, quando ví saliendo una Sangre tan preciosa de un Cuerpecito tan tierno! y más al ver a sus Payres, dambos llorando y gimiendo.

Quando cata que un triz se descolgaron del Cielo, lo mesmo que la otra noche tanto Angelote tan bellos pegando unas lumbraraas, que me queé como ciego, traiban en un escúo de repúsculos muy lleno de Jesús el Dulce Nombre, muy bien bordao y muy gueno. Al ver esto me queé como un tonto boquiabierto, $y$ tal me engolosiné con tantísimo embeleso, que no quería apartarme ni un rato dell Portalejo. Pasaos muy pocos días, 
estando contando el cuento I

del Nacimiento a Rebeca,

vimos venir a lo lexos

una Estrella muy jermosa,

tamaña como un Llucero,

mos metimos en la Corte,

porque en verdá me dió mieo:

supimos luego que eran

tres Tagarotes muy tiesos,

montaos en Albestruces

con muncho acompanamiento:

anduvieron por las calles

de la Ciá, y estovieron

conviaos con Heroes

aquel dia, $y$ en saliendo

se endilgaron a Belén,

y jueron al Portalejo:

pararon alli un gran rato,

y unas caxetas abriendo,

regalaron al Choquito,

20

yo no sé lo que le dieron:

ésta por ser tan coriosa,

puso más coriao en ello.

Reb. Tres cosas le presentaron

al Niño los Caballeros:

una relumbraba muncho,

$y$ las otras yo no pueo

destinguir lo que serían:

lo que ví, jué, que en un tiesto

jicieron un gran jumaso,

y el jumo jeía a encensio.

Ansina que arremataron,

montaron en los Cigueños,

otro camino tomaron

destinto del que truxeron.

Isac. Quienes eran estos hombres?

Jos. Pregunté a un Negro de aquellos,

y me ixo que eran Magros

y venían del Oriento:

lo que yo pueo diciros,

que el delantrero era un viejo,

99]

el otro era un mozo rubio,

y el rezaguero era un Negro.

Isac. $\mathrm{Y}$ dime, Jusepe mio,

¿porqué estabas tan en ello

baylando aquí con Rebeca?

Jos. Porque en este Santo Tempro

hoy han presentao al Niño, 
y jué tan grande el contento

Isac. Lo mesmo que tuve quando lo ví, que me eché a baylar.

hubiera yo executao

al ver su Presentamiento:

pus ese Divino Niño,

sende que lo ví, confieso,

que cautivó mis potencias.

Por dichosos mos debemos

10

tener toa muestra vía,

porque juimos los primeros

que Humanao le aoramos,

llamaos al mesmo efleuto.

Jos. Ansina es, que los Magros

han sío los rezagueros.

En fin, Rebeca, ya es talde,

vamos a la Aldea luego,

que Mayre estará esperando

el lavao, discorriendo

20

Isac. Pus a Dios, y vénte presto, que en la majaa te esperamos.

Jos. y Reb. Jasta más ver, caballeros.

Vánse Isaac y Jacob por un lado, y los demís por otro, 25 $y$ aparece $S$. Josef dormido.

Mús. Desde la Ciudad de Egypto

te está tu Padre lamando,

apresúrate, Jesús,

a obedecer el mandato.

Baxa S. Gabriel, aplicase al oido de San Josef $y$ le dice.

Gabr. Levántate, Josef, $y$ sin tardanza

Con el Niño y su Madre parte a Egypto,

En donde babrás de estar hasta que vuelva

A avisarte otra vez de tu destino;

Pues indignado Herodes y furioso

Ha de buscar con ira a Jesu-Christo:

$\mathrm{Su}$ intento depravado es darle muerte.

Desaparece el Arcángel, $y$ dice en suetios San Josef.

S. Jos. Aguárdate, embeleso, dulce hechizo,

Suave encanto del alma, hermoso Jóven,

¡Qué presto te ausentaste, ó Paraninfo!

¿Qué presto me dexaste, Santo Arcángel!

Vuelve otra vez, atiende, en qué conflicto,

En qué pena, dolor $y$ sobresalto

Me dexas, $y$ te vas ... Oh, Jesús mio! 
Alabo sin cesar, Dueño de mi alma, Leván/ase. Vuestros grandes Secretos y Designios.

O quan presto, Dios mio, comenzais

A hacer ver a los hombres lo encendido

De vuestro inmenso Amor tan generoso,

Que arde ya en vuestro pecho compasivo,

Ansioso por salvarnos de los males,

Con que heredamos el primer delito.

Permitidme, Señor, en desahogo

10

De un corazón turbado y afligido,

Os haga yo una súplica nacida

Del amor que os profeso, como a Hijo.

Dilatad, Dueño mio, haced que tarden

Esas persecuciones y martyrios.

No empezeis ya tan presto por el hombre,

A sentir y a sufrir, que soys muy Niño,

Pasad, aunque en pobrezas y trabajos,

Siquiera la niñez con el alivio,

$\mathrm{Y}$ al descanso, que puede franquearos,

El estar yo sirviéndoos complacido,

Con sudor de mi frente trabajando,

Para que asi no os falte el regalito:

Asimismo María vuestra Madre,

que se esmera en cuidaros y asistiros.

De este modo pudiérais, dulce Prenda,

Disfrutar en la Infancia aquel abrigo,

Que permite el vivir en nuestra Patria

Entre Deudos y Amigos, recogidos

En el pobre rincón de nuestra Casa.

Quisiera, Dueño mio, que este alivio,

Vuestra Piedad benigna me otorgase.

¡Oh, qué presto, Seffor, aquel cuchillo

Que anunció Simeón ha comenzado

A herir con su cruel y agudo flo!

1Cómo podré sufrir la dura pena

De ver a mi Jesús, un tierno Nifio,

Caminar los desiertos dilatados,

Que median de este Reyno hasta el de Egypto!

¡Qué amarguras tran ġrandes, qué aflicciones

Pasará el corazón al ver mi Niño

10!]

Expuesto a la inclemencia de los tiempos,

Sin amparo, consuelo y sin abrigo!

|Qué dolor será este tan intenso|

QQué pena tan atroz y qué martyrio

Tendrá mi corazón al ver su Madre

Pasar unos trabajos tan crecidos!

Yo quisiera, Dios mio, dispensases 
De esta pena a María y a su Hijo,

$\mathrm{Y}$ que yo todo junto lo sintiese,

Aunque fuese mayor este conflicto.

Gustoso sufriría los trabajos

Por librar a mi Esposa del prolixo

Dolor, el más agudo que le espera,

Al ver ya tan temprano perseguido

Al Inocente Dueño de su Alma, Huyendo, Desterrado y Desvalido, Caminando jornadas tan penosas.

Mas ya veo, Señor, que son Juicios

De vuestra Providencia inexcrutable,

Por lo qual me conformo y me resigno.

Dadme fuerza, Dios mio, para darle

A mi Sagrada Esposa un tal aviso,

Para que resignada su obediencia,

Se aliste y se prevenga con su Hijo

A emprender la partida en esta noche

Según la anunciación del Paraninfo.

\section{Váse.}

Mús. Sal, Divino Peregrino,

a los montes, selvas, campos, que si el hombre te persigue, estos te darán amparo.

Aparece la Virgen en su relrele, sentada con el Niño en brazos.

No te detengas, Jesús,

en huir del Rey tirano,

que aunque eres Omnipotente,

ahora conviene ocultarlo.

Desde la Ciudad de Egypto

te está tu Padre llamando,

apresúrate obediente

a executar el mandato.

Huye del Infiel Hebreo, acógete al fiel Pagano,

10

que aquel te dará la muerte,

y éste será fiel Christiano.

Sale San Josef, y con reverencia dirá a la Virgen.

S. Jos. Esposa y Señora mía, no sé cómo he de anunciaros

la voluntad del Señor.

\section{Levántase la Virgen.}

Desde luego preparaos

a sentir y a padecer 
al Señor que padezcamos.

Su Santo Arcángel en sueños

me ha dicho $y$ me ha declarado,

dispone y ordena Dios

que con el Niño nos vamos

huyendo a Egypto, porque

trata Herodes Rey tirano,

sacrílego, atroz, quitarle

10

la Vida; $y$ así animaos

para partir esta noche.

Mar. Es muy justo recibamos,

Esposo mío y Señor,

con resignación y agrado

de mano de nuestro Dios

los temporales trabajos

con que nos quiere afligir,

así como de su Mano

recibimos tantos bienes.

Benditos sean y alabados

Sus Altísimos Juicios.

No os afijais, consolaos, pues llevamos con nosotros

al Criador Soberano

de los Cielos y la Tierra;

con esto, ¿qué sobresalto

hemos de tener? a vista

de llevar en nuestro amparo

a este Dios: con su Poder

nos librará del tirano

Herodes que nos persigue:

sin detenernos, partamos

para Egypto en esta noche,

a obedecer el mandato

de nuestro Dueño piadoso.

Mirando al Niño con gran ternura, le dirá.

Hijo mio bello encanto,

dulce hechizo de mi alma:

no importa, que desterrados

vayamos huyendo a Egypto,

si con nosostros llevamos

el Sumo Bien, nuestra Gloria,

nuestra Patria, nuestro Amparo,

nuestra Vida, nuestra Luz,

y todo nuestro bien llevámos.

¡Quan distintos, Hijo mio, 
quan distintos, qué contrarios son los intentos del hombre y los vuestros Soberanos! él solicita perderos, y Vos con acelerado paso le buscais, por darle vida, bien, gracia y descanso. ¡Pero quién alcanzará tan Altísimos Arcanos! Ea, prevenios, Hijo, to disponeos, preparaos a padecer y a sentir destierros, penas, trabajos, y dadnos vuestra licencia para ir acompañándoos. Vánse.

Mús. Desde la Ciudad de Egypto te está tu Padre llamando, apresúrate, Jesús

a obedecer el mandato.

Fin. 
La Huida a Egypto de $\mathbf{N}^{\text {tro }}$ Señor Jesu-Christo.

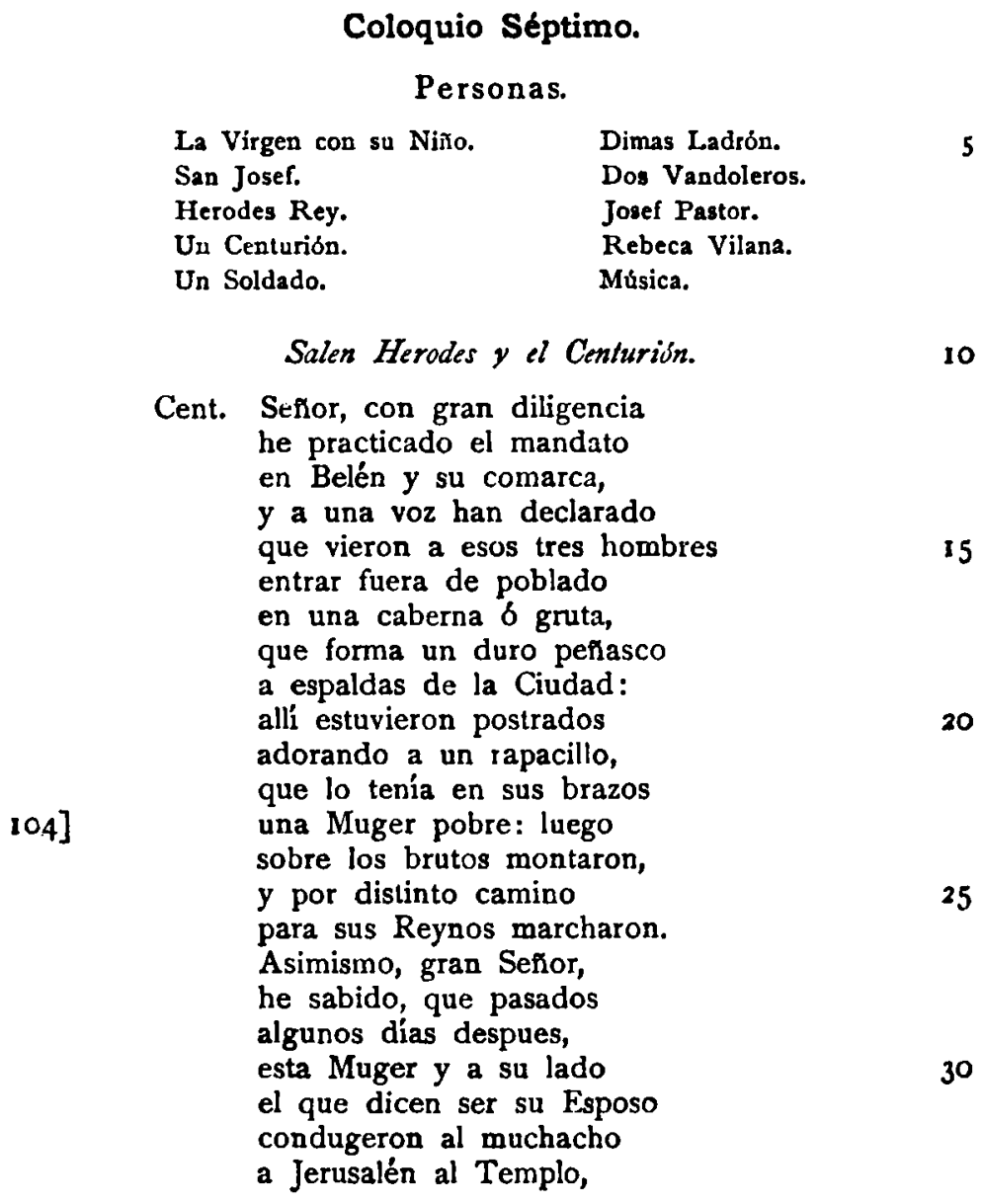


que lo recibió en sus brazos

Simeón, y que éste dixo

ser el Mesías Sagrado

que el mundo espera: al instante,

para más certificarlo,

dispuse pasar al Templo,

mas fué envano mi cuidado,

porque ya este Simeón

a impulso de luengos años

rindió a la Parca su vida:

lo que me ha desconsolado

IO

súmamente, porque queda

sin averiguar el caso

con la claridad que pide

siendo tan urgente $y$ arduo:

que lo siento, es evidente,

pues bien sabeis me he preciado

en todo tiempo de seros

el más fiel é interesado

en vuestro honor. Tambien supe

(no quisiera molestaros

con noticias tan indignas,

que os causarán desagrado).

Herod. No te detengas, prosigue.

Cent. Supe, Señor, que el Muchacho

para ser tan aplaudido

y por Príncipe aclamado,

es de infeliz Nacimiento;

pues hoy me han asegurado

hombres de verdad, que el Padre

es un pobre desdichado,

únicamente atenido

al trabajo de sus manos,

en las tareas que exerce

de Carpintero: este agravio,

esta infamia, este delito

$y$ este enorme desacato,

si no procurais vengar

con un castigo el más raro,

que cause terror al Reyno,

y el más horroroso espanto

a todo el Orbe, se queda

vuestro honor muy agraviado.

Herod. Que así aquellos tan groseros

de mí se hubiesen burlado!

que no los hubiera preso!

¡que no hubiese yo arrestado

a quienes $\tan \sin$ respeto 
mi Magestad injuriaron!

que esto le suceda a un Rey!

no soy quien soy, si no hago

para escarmiento del Reyno

el castigo más extraño,

que en el mundo se haya visto

en defensa y desagravio

de mi honor. Muera el Rapaz,

mueran sus Padres y quantos

intentaren oponerse

IO

a mis designios: cuidado

que se observe puntual

el decreto que te encargo,

y entonces sabré, si eres

por mí el más interesado

en lo que toca a mi honor,

de ti solo he confiado

este mi designio. Al punto,

que sa alisten a tu agrado

de mis tropas los que basten

para tu auxilio y resguardo,

y que salgan en patrullas

por todas partes buscando

con el debido sigilo

y el más exacto cuidado

a ese Rapaz atrevido, que intenta con desacato destronarme, (mal he dicho)

que no es capaz de pensarlo, viviendo en el mundo Yo:

$y$ al instante que sea hallado,

le traigan a mi presencia,

para darle yo a mi salvo

el castigo que merece:

y a sus Padres por osados

luego al punto darles muerte.

Esto fio a tu cuidado,

como de tanta importancia,

para que desagraviado

quede mi honor de esta suerte:

no dilates practicarlo.

Cent. Mi lealtad, gran Señor, solo teme no encontrarlo, que diligencias exactas no omitirá mi cuidado y la más seria inspección, qual pide caso tan arduo; $y$ así quedad entendido, 
que siendo yo el ellcargado, si le encuentra mi furor, lo vereis bien castigado; pues he de ser el verdugo, siendo Vos el injuriado, que haré de su cuerpecillo con mi acero mil pedazos.

Herod. ¿Que así me traiga un Rapaz con tanto miedo y cuidado, con tanto zelo $y$ fatiga, tanto horror y sobresalto! ¡que el ser Rey no me dispense de tan amargo cuidado, de zozobra tan cruel! ¡que me traiga desvalido, sin descanso, sin sosiego, sin quietud, solo un Muchacho! rubor me causa el decirlo, vergüenza es el pronunciarlo, es contra mí el proferirlo, me ofende solo el pensarlo. ¿Por ventura mi poder ha dado fin, he espirado? ¿se le han cortado los vuelos al dominio Soberano, que como Rey poseía? miente quien pensare osado tal vileza, miente, miente $y$ es un traidor, mal vasallo, digno de mi indignación. Sepa mi Reyno Judayco, si maquina contra mí un tan infame atentado, sepa que vive sin mengua el Cetro Real en mi mano, y con él el duro acero para castigar a quantos a mi fuerza se opusieren; y así, mueran los que osados intentan viles $y$ aleves ofender al soberano honor de mi Magestad. Muera el Rapaz, muera a manos de los sangrientos verdugos, pague su vida el agravio, la injuria, el atrevimiento, la ofensa y el desacato contra su Rey tan enorme. 
$\mathrm{Y}$ si se cscondiere instado

del micdo ese traydorcillo,

huyendo de mi indignado

furor, yo sabré buscarle

por medio de mis Soldados,

$y$ aunque en lo más interior

de la tierra acobardado

se ocultase, mi poder

sabrá muy bien encontrarlo

y darle su merecido

10

a lo atroz de su pecado.

En fin, si ya no lo hallasen

mis diligentes Soldados,

no ha de quedar en Belén

ni en sus Pueblos comarcanos,

infante alguno con vida,

y puede ser que entre tantos

inocentes pague el Reo

su delito temerario.

Confieso ser crueldad,

pero mi honor es más alto,

20

importa más que la vida

é interés de mis vasallos.

Mueran y con eso paguen

la culpa que no adeudaron,

que entre inocentes quizá

morirá este vil culpado.

Váse, y salen la Virgen con su Niño y S. Josef de camino.

Mús. Jesús, Maria $y$ Josef

alegran con su presencia

los desiertos, las montañas,

los campos, valles y selvas.

S. Jos. Dulcísima Prenda mia, yo quiero vuestra licencia para disponer que un rato descanseis en estas selvas,

que el frio, yelo y escarcha

nos causan muchas molestias:

Por mi Jesús y por Vos

lo siento: mi amor quisiera

nada os ofendiese, y solo

en mi juntos recayeran

estas penas y trabajos,

aflicciones y miserias.

Mar. Pronta estoy a obedeceros.

En esta florida selva

parce que encontraremos 
por la amenidad que muestra

el refrigerio del agua:

y la Grande Providencia

de nuestro Dios, atendiendo

a la continua miseria

de sus pobres criaturas,

acudirá a socorrerlas,

que los árboles, las plantas,

y quanto hay en la tierra,

para el hombre lo crió

10

su Divina Omnipotencia.

Vamos, venerado Esposo,

y descansará la Prenda

de mi Alma. ¡ Oh Jesús mio,

como siento que padezcas

tantos trabajos! Qué presto

principió vuestra Clemencia

a manifestar al hombre

de vuestro Amor las finezas.

Dentro voces, $y$ dice Dimas.

20

Dim. No quede monte, ni valle, camino, vereda $\delta$ senda, que no se vea $y$ registre.

Mar. Josef, qué voces son éstas?

107]

Jos. Ay, Esposa de mi Alma!

¿si será la tropa fiera

de los verdugos de Herodes?

Ay, Jesús mio, qué pena!

haced una ostentación

de vuestra Inmensa Grandeza,

librándonos del peligro,

que $\sin$ duda nos rodea.

Apártase a un lado, y dice dentro el Vandolero primero.

Vand. I. Alerta, mi Capitán, que he descubierto en la selva

humanas huellas: venid

para asegurar la presa.

Dimas dentro.

Dim. Avanzad sin detenerse:

llevad lista la ballesta,

la flecha en la puntería, por si hubiese resistencia.

S. Jos. Ay Jesús del alma mia!

El corazón se me anega

de amargas tribulaciones, 
oyendo que ya se acercan

declarados enemigos

de vuestra Bondad: qué pena,

Esposa mia, rogad

a ese Rey del Cielo y tierra,

a ese Dios Omnipotente,

que en vuestros brazos venera

mi respeto, que nos libre,

nos ampare y nos defienda

de este asailto tan funesto

10

que a todos tres nos espera.

Salen de pronto los dos Vandoleros, vestidos de pieles, desgrenados con carcaces a las espaldas y flechas en la punteria.

Vand. 1. Daos a prisión, $y$ no oseis poner mano a la defensa, que rendireis vuestras vidas al impulso de estas flechas.

El Vandolero segundo mirando a dentro, dirá.

Vand. 2. Dimas, Capitán valiente, ya está segura la presa, a la selva has de acudir.

Dim. Ya lo emprendo, el ojo alerta.

S. Jos. Hijos de Dios, no olvideis, que soys imảgenes bellas de ese Padre, que es la suma Bondad, Piedad y Clemencia: por lo tanto a compasión moveos $y$ no a fiereza, que ésta es propia de los brutos y del hombre muy agena: no hagais vuestros corazones, que son de carne, de piedra: mirad que somos dos pobres, sin tener otra riqueza que poderos franquear que este Infante, en quien se encicrra nuestro tesoro; por él que es verdadera Inocencia, os pido humilde y postrado,

Se arrodilla.

excuseis toda violencia, $y$ si fuere indispensable, recayga en mí toda ella, $y$ queden libres $y$ exentos Madre \& Hijo: esto os ruega 
vuestro esclavo el más rendido,

I hacedlo par vida vuestra;

no receleis en nosotros

fuerza alguna ó resistencia, que sin armas, bien segura teneis tan humilde presa.

108] Sale Dimas lo mismo que los otros y apunlando.

Dim. Escusado es todo ruego: maniatadlos con presteza.

S. Jos. Señor! por Dios os suplico, que nos mireis con clemencia.

Los Vandoleros se echan a las espaldas los arcos y flichas con diligencia, $y$ zan a maniatar a San Josef: Dimas mira al Niño, $y$ al punto se le caen arco y flecha, $y$ dice con furor a los otros.

Dim. Qué vais hacer?

há traidores sacrílegos.

Los 2. Lo que ordenas.

Se detienen.

Dim. ¿Cómo osais tan mal mirados

20

contra la misma Inocencia

poner manos alevosas?

al primero que se mueva

he de hacer su cuerpo trozos

para pasto de las fieras.

Qué haceis parados?

Los dos vuelven a embestir, y él con ira los detzene.

Malvados!

qué intenta vuestra fiereza?

no obedeceis lo que os mando?

30

Los 2. No entendemos lo que ordenas.

Dim. Que al punto rindais las armas:

Rinden las armas a los piés del Niño.

que no oseis hacer violencia en mi presencia a este hombre.

Da la mano a San Josef y lo levania.

S. Jos. Dios te pague la clemencia.

Dim. A esta Señora, a este Niño, que tras sí el alma me lleva, el corazón me ha robado, me ha embargado las potencias, cautivando mi alvedrío, 
y embolando mi fiereza.

Qué es esto, Divino Niño!

iyo que venía a hacer presa

de Vos, y Vos de antemano

por Providencia secreta,

que no alcanzo, me robasteis

todo quanto en mi se encierra,

pues no habeis dexado en mí

facultad que no sea vuestra!

lqué enigma tan prodigioso

es éste! que mi fiereza

se convirtió en mansedumbre,

mi crueldad en clemencia,

toda mi furia en cordura,

mi bronquedad, mi braveza,

y mi rigor trastornados

en voluntad $\tan$ sincera,

que mis ansias solo aspiran

a serviros con atenta

disposición, y a obsequiaros,

$y$ si es forzoso, en defensa

de vuestra vida perder

una $y$ muchas que tuviera,

porque nadie os ofendiese

muy gustoso las perdiera.

Este amor, este volcán,

que en mi pecho fiel se encierra,

desde el instante que os ví

en esta florida selva,

nace de la gratitud,

sin saber por qué influencia;

IO9]

pues Vos, prodigioso Niño,

me dice el alma sincera,

habeis de hacerme feliz

con tanta magnificencia,

que seré pasmo y asombro

de la dicha más excelsa:

por tanto dexad que bese,

postrado humilde en la tierra

póstrase y besa al Ninto los pils

vuestras plantas, Dueño mio,

que mi lealtad hoy quisiera

saberos agradecer

con fina correspondencia

el superior beneficio,

que espero con evidencia

habeis Generoso y Franco 
de hacerme: ojalá pudiera

teneros siempre a la vista, porque el veros me consuela.

\section{Leziantase.}

Señora, si os es posible, dexad conmigo esta Prenda, haced cuenta que furioso os lo arrebaté por fuerza: no os llevais alhaja tal, porque sin alma me dexas; y si no, quedaos conmigo a vivir en estas breñas, que no os faltará el albergue, aunque no a correspondencia de lo que Vos mereceis, y este Niño: ¡quién tuviera un Palacio en que hospedaros! pero por fin una cueva, aunque pobre, con aseo, aunque tosca, con limpieza, no os faltará, ni el regalo, qual estos montos dispensan, ni quién os sirva leal con profunda reverencia: mi muger, mis hijos y estos, que aquí veis a mi obediencia 10 serán vuestros fieles siervos, yo tambien, como cabeza de mi familia seré el primero que obedezca puntual vuestros mandatos; no desprecieis esta oferta, que la hace quien os ama con un amor muy de veras.

Mar. Mi voluntad te agradece

tan fervorosa fineza:

del Cielo tendrás el premio, porque usaste de clemencia con estos tres Peregrinos, que siguen la Providencia del Señor, Dios de Israel. Perdona, no condescienda con tus amantes deseos, porque es convieniente emprenda con mi Niño y con mi Esposo así lo dispone el Cielo. 
Dadnos, pues, vuestra licencia, I para seguir la jornada.

Dim. Antes quiero me concedas que mi muger y mis hijos gozen de vuestra presencia. Venid conmigo, Señores, que cerca tengo mi cueva, descansareis algun rato de las continuas molestias del camino, $y$ tomareis refrigerio en frutas secas, que es el tributo que dan estas ásperas malezas.

IIo] Jos. Vamos, Esposa, que es justc demostración, con que Dimas en esta ocasión se esmera,

Mar. Mi Hijo te premiará apart. porque $\tan$ fino le obsequias,

Vánse, $y$ por olra parle salen Josef con una porra en la 20 mano, y Rebeca.

Reb. Oyes, Jusepe, ¿has sabio a qué fin vino a la Aldea anteyer el Centurión con su Compañia entera?

Jos. Eso a mí no me preguntes, que te lo iga una tuerta.

Reb. En las casas se soplaban, llamaban a las caseras, jaciéndolas mil preguntas, sin que naide las oyera. Jusepe, qué mos vendrá?

Jos. Nunca será cosa guena; ya resollará algun dia, y quiera Dios que yo mienta.

Reb. Qué ha de resollar, Jusepe, no anuncies ya malas nuevas.

Jos. Resollará que los Niños resuellen sin la cabeza.

Reb. No te entiendo ese latín.

Jos. Jo si, y ojalá pluguiera, no juera como lo pesco, que estonces no se vertiera tanta agua $y$ tanta sangre.

Reb. Dí craro ese traballenguas.

Jos. Eso Rebeca, jué un sueño que tuve anoche, si vieras, 
desperté tan aflegío,

con tal dolor $y$ tal pena,

que solté el trapo llorando

como los niños de teta;

pus aunque estaba ya en mí,

me parecía de veras.

Reb. Pus qué jué lo que soñaste?

dímelo porque lo sepa.

Jos. ¡Qué amiga de apurar eres

siempre toas las materias.

IO

Reb. Preciso, sí soy coriosa.

Jos. $\mathrm{Y}$ un poquito zalamera.

Reb. Vamos, exprícame el sueño.

Jos. Sacarás jugo a una peña.

Como estas días ha andao

el Centurión en la Aldea,

por las casas pesquisando, soñé que una chusma fiera de sayones $y$ verdugos

a porfía, sin reselva,

degollaban desalmaos

todos los Niños de teta:

sus mayres lloraban tanto,

que se escuchaban las quexas

jasta en la Ciá de Roma,

sin que en too el Puebro hubiera

quien pudiera consolallas,

ni enjugar en tanta pena

las lágrimas que arrojaban.

Reb. $\mathrm{Y}$ porqué era esa trageria?

Jos. Porque a Jesús no topaban:

invidiosas deligencias

de un Rey, que quiere seguir

con una ambiciosa tema

de ser solo, y que nenguno

le baraje su grandeza.

No hay mal peor que la invidia, porque trueca al hombre en fiera desatinándolo tanto

que ni al mesmo Dios respeuta.

Reb. No quiera Su Magestá, que tal desgracia socéa, porque estonces el joicio de pena sc me golviera.

Jos. Pus acaso ercs tú mayre?

Reb. Soy tía, que tanto pesa, y siento los sobrinicos, que bien sabes son dos pelras. 
Conque en fin eso jué sueño?

Jos. $Y$ puee salir de veras:

a lo menos no sería

el primero que se cuenta.

De José gran Patrialca

se dice por cosa cierta,

tuvo una ocasión dos sueños;

que le salieron de veras:

uno jué el de los manojos

de espigas, quando la siega,

IO

y otro el del Sol y la Luna

con aquellas once estrellas,

$\sin$ otros munchos que ha habio,

y yo me sé.

Reb. El Cielo quicra

no sea tu sueño ansina,

porque eso juera una pena;

de oillo se me estremece

el cuelpo, $y$ me da dientera:

Conque en fin, ¿ no me irás

a qué son las deligencias

que están jaciendo esos hombres

en el Puebro con tal priesa?

Jos. Qué sé yo lo que te iga:

lo que se suena en la Aldea

por cosa fixa, es, que Heroes

estaba echando las muelas

con los Magros, que se jueron

sin haber dao la guelta

por la Corte, como ansí

le jicieron la plomesa:

esta bulra la ha sentio

de tal manera su Alteza,

que se ha puesto muy rabioso,

con tal corage $y$ sobervia,

que dizque si los pillara,

les cortara las cabezas, porque semejantes tratos

solo negros los tuvieran.

Reb. Lo dirá por el Rey Negro,

que los demás brancos eran.

Jos. En fin, él los esperaba, $y$ le han jugao una treta, por lo qual el Centurión con su Compañia entera anda por esa comarca perquizando si hay quien sepa donde está el Niño Jesús, 
y sus Payres: mas se suena que tambien anda indigando con munchísima cautela, quiénes jueron los Pastores, que en aquella Noche guena jueron al Portal.

Reb. Y qué, se ha sabío?

Jos. No, Rebeca, cómo es posible, si a nadie del Puebro se le dió cuenta, si no es a tí solamente.

Reb. De mi boca, estoy muy cierta, no lo oyó presona alguna.

Jos. Maravilla es estupenda, porque nunca las mogeres

han sabio ser secretas: apenas se les encarga, que alguna cosa en sí tengan, quando les dá mal de mayre, y por dicillo rebientan.

Reb. Pus de mí sé yo dicirte, no tienes tal experiencia.

112] Jos. Porque no te encargué estonces, que el secreto retuvieras; pus si lo hubiera encargao, solamente lo supieran en caa casa un vecino, y si un poquito me aprietas, diré que ya lo sabrian jasta los niños de teta.

Reb. Ea gueno, que el zagal se apea por las jorejas.

Dentro ruido.

Jos. A ver, calla, que parece suena gente en la verea, me asomaré a ver quién viene.

Al ir sale el Centurion, y queda Josef corno turbado, temblando.

Cent. Dios os guarde: de qué tiemblas? has visto alguna fantasma? 6 piensas que yo soy fiera?

Jos. Como estó siempre criao

a lo cerril entre bestias, en viendo gente me turbo, y me da muncha vergüenza. 
Cent. Lástima es, que esas enaguas I este hombre no las tenga, porque al parecer más traza tiene que tú de ser hembra.

Reb. Señor, mi helmano es muy corto y además jecho a la sierra.

Cent. Dime, hombre, en qué exercicio te ocupas ó en qué tareas?

Josef turbado.

Jos. Qué me ha dicho Somercé?

10

Hablando con Rebeca.

Reb. Ay, Dios mio, y qué tontera! que digas a este Seffor, sin miaja de vergüenza, ni corteá, en lo que buscas la vía por esas sierras.

Jos. Yo aunque indigno soi Zagal, que me ando en las ovejas.

Cent. Mejor te pegara andar (apart. con el huso y con la rueca. Conque siendo tu el Zagal, que anda con las ovejas, es consiguiente no ignores, antes bien por fixo sepas, lo que voy a preguntarte. ¿Sabes tú por estas tierras donde para una Muger, que dicen ser Nazarena, de tierna edad, con su Esposo y un Hijo, que en una cueva de los muros de Belén, (propio alvergue de las bestias) lo parió noches pasadas? y han dicho para más señas, que fueron unos Pastores a visitarla a la cueva, y despues con aparatos de Regia magnificencia vinieron tambien tres hombres (yo los ví), de lexas tierras, y se decía ser Reyes, los quales fueron a verla con el Infante nacido, y cumplidos los quarenta días de su parto, han dicho, desamparó la tal cueva, 
porque fué a purificarse

conforme la Ley ordena, y despues no se ha sabido donde esté, pues no dió vuelta al lugar del Nacimiento.

Tu es forzoso que lo sepas, siendo Pastor, y quizá si no me mienten las señas, uno de aquellos que fueron tan comedidos a verla.

No me lo niegues, que yo lo sé con toda certeza. Si lo ocultas, porque temes, te sobrevendrá molestia, está scguro que no, antes bien el premio espera:

porque has de saber que el Rey mi Señor es quien ordena se haga esta inquisición con eficaz diligencia y cuidado el más prolixo, porque pretende su Alteza favorecer a este Infante y a sus Padres, por secretas obligaciones y cmpeño, que a su Real pecho reserva:

por lo tanto, al que leal diese una noticia cierta donde para esta Familia, promete la recompensa, que será de su Real gracia una exquisita fineza: y asi sabiéndolo tú me lo dirás con presteza.

Jos. Que me enmielen si lo sé, agora es la vez primera, que semejante noticia ha llegao a mis jorejas.

Cent. Difícil ine es el creerlo, siendo público en la Aldea.

Jos. No lo estrañes, porque yo, como estó con las ovejas, no entiendo más que del jato, y no es esto poca briega: en lo emás no me meto, porque no es de mi encumbencia, ni que aborten las casaas, ni que paran las doncellas, 
ni que vayan los Pastores,

ni que los Reyes se vengan,

ni que Belén con sus muros

de arriba abaxo se guelva:

pregúntame de cabaña,

de carneros ú de ovejas,

cómo se jacen las migas,

un gaspacho ú cachorreñas,

y verás como al menute

te doy pronta la respuesta.

10

Cent. Y tú? qué dices, muger?

declárame lo que sepas.

Reb. Yo, Señor, no lo he sabio, porque como só doncella, mi mayre no me permite,

ni aún asomarme a la puerta,

$y$ ansina las noveaes,

que por afuera se suenan,

son para mi (muerta en vía)

como si acaso no jueran:

20

y lo más peor de too,

es, que mi mayre no quiera

ni aun el que vaya a baylar

a las jiestas de la Aldea, que esto me llega a lo vivo

del corazón con gran pena,

y más quando sé tocar

tan diestra las castañetas.

Jos. Si, señor, las toca bien,

como que ha sío maestra

de munchísimas zagalas:

sí puee poner escuela,

aunque sea allá en la Corte:

es un pruigio Rebeca.

I 4] me las jarréo con qualquiera:

no hay Pastor en estos montes,

ni en toita la Judea,

que la toque como yo

con más primor $y$ destreza.

Sí la jago yo jabrar.

El Centurión se enfada, y Josef se asusta.

Cent. Escusa ya esas frioleras.

Que no se pueda apurar (apart.

la realidad de esta empresa,

sin embargo de haber hecho

tan prolijas diligencias! 
qué sentirá el Rey Herodes, quando a su presencia vuelva sin haber adelantado paso alguno en la materia. $¿$ Que es posible no sepais de este asunto ni una letra? pues mirad, que se previenen en la Corte graves penas al que lo sabe y lo oculta. Qué deciis? no dais respuesta?

Se encogen de hombros

ahora es tiempo, declarad lo que sepais sin vergūenza. Donde para ese Muchacho? donde esa Muger se hospeda? $¿$ decid sin temor alguno quién los oculta en la Aldea?

Reb. Señor mio, de mi parte yo os he dado la respuesta.

Cent. Y tú, Pastor, qué me dices?

Jos. Lo que igo es cosa cierta, y no me lo ha icho nayde, pues agora se me acuelda. Osté los quiere topar?

Cent. Donde están? Dí con presteza.

Jos. Pus búsquelos Somercé con coriao y deligencia, que ellos han de estar preciso.

Cent. Dónde?

Jos. Entro el Cielo y la Tierra.

Centurión enfadado.

Cent. Villano, infame, atrevido, te burlas en mi presencia? eres traydor, $y$ por tanto castigaré tu insolencia.

Jos. Señor, que éstas no son bulras, pus lo jgo muy de veras.

Cent. Ni el castigar tu osadía serán burlas, sino veras. Ha de la Guardia!

Sale el Soldado primero.

Sold. Señor!

Cent. Arrestad por su insolencia a este villano traydor. 
Sold. Que tu me haces resistencia?

Rebeca se posira.

Reb. Señor, Señor, no haga cașo

de las palabras groseras

de mi helmano, que son jijas

de su montaraz rueza;

no es su intento ofenderos,

pus es muncha su inocencia.

$$
\text { Josef ain forcejando. }
$$

Jos. Vaya, no me samarree, que no só Alvarcoque, ea, suélteme osté, que me voy a andar tras de mis ovejas.

Cent. Bergante, tu atrevimiento pagarás con la cabeza: conducidlo a la prisión.

Jos. Ay, Rebeca, que me llevan a darme de coscorrones!

Reb. Señor, moveos a clemencia: por vuestro honor os lo pío.

Queda el Centurión algo delenido.

Cent. $\Lambda$ esta su hermana agradezca, que no le doy el castigo debido a su desvergüenza. Dexadlo por mentecato, $y$ otra vez no te acontezca semejante groseria.

Suéllanlo, dánle un golpe, vánse, y levántase Rebeca.

Reb. Dios te pague la fineza.

Jos. Con un costurón de bota en sus lindas posaeras. No tengo fe con nenguno de estos Armaos, pluguiera se acabara esta semilla de bribones, que no piensan más que en jacer daño a toos. Coriao que es cosa cierta: en viéndolos me reboto, y queo jecho una pieza. 
Reb. Agora tuviste tú

la culpa de esta pelea, porque te se jué la mula sin reparo en su presencia, y como estos son señores, no gustan de cuchufletas de gentes como nosotros, que semos de baxa esfera: siempre es muy gueno, que caa oveja con su pareja. Para tratar con Señores, es menester tener cuenta con meir bien las palabras.

Jos. Pus mira, gran bachillera, no te mia las costillas con esta porra: tú piensas que acaso me mamo el deo? ¿pues qué quería el muy pieza, que yo le ixese agora una cosa como ésta? mamóla para el bribón; vaya a escardar, que mi llengua no está jecha a ser soplona: querías tú descobriera a un indino como él, de $\tan$ dañaa concencia unos Misterios tan altos, que no a toos se revelan, sino a los probes y humildes, que son los que Dios aprecia, y no a estos vengativos, jinchaos con la sobervia : noramala para él, váyase luego a su tierra como se vino, que yo no só bobo como piensa, y si no, méteme el deo para ver si tengo muelas de corcho, como al bergante le pareció. Vamos de esta a la Aldea, pus no quiero que otro aprieto me socéa. Lo que juere, tronará, ojalá que yo mintiera.

Reb. Siempre anuncias cosas malas, no quiera Dios que tal sea. Vánse. 
La Degollación de los Santos Inocentes.

\section{Coloquio Octavo.}

\section{Personas.}

La Virgen.

Dos Verdugos.

San Josef con Jesus.

Raquél con su Nirro.

Dimas Ladrón.

Isaac Rabadán.

Dos Vandoleros.

Jacob Pastor.

Herodes Rey.

Josef Pastor.

Un Centurión.

Rebeca Villana.

Dos Soldados.

Música.

Salen S. Josef con Jesuis en brazos, la Virgen de camino, $y$ delante Dimas, y los dos Vandoleros cono guiándolos.

Dim. Aqui, Señores, termina

lo fragoso de la sierra,

lo que sigue es apacible:

ésta que véis es la senda

por donde al camino recto

llegareis: ó quien pudiera

seguiros acompañando!

Mar. Vos, amado Josef,

conceded vuestra licencia, para que venga a mis brazos

mi Jesús, mi amada prenda.

Se lo entrega.

S. Jos. Tornadlo, Sagrada Esposa

y sigamos la carrera, si os agrada, en cumplimiento

de lo que el Señor ordena;

que yendo yo a vuestro lado, $y$ al de mi Jesús, no hay pena, tribulación, amargura, 
ni trabajo, que yo tema.

Vamos a Egypto, Señora, huyendo de la sangrienta envidia del Rey Herodes, que tengo esperanzas buenas de hallar entre los Infieles más piedad que en la Judea, hasta que el Cielo disponga, se serenen las inquietas tiranas solicitudes, 10 y volvamos a la tierra. Dueño, Señor y Dios mio, encaminad nuestras huellas, librándonos, Poderoso, de todo lo que os ofenda. Vansia:

Mus. Huye del infiel Judio, acógete al fiel Pagano, que si aquel te desconoce, en este hallarás amparó.

Desde la Ciudad de Egypto, te está tu padre llamando, apresúrate, Jesús, a obedecer el mandato.

Suena caxa, y salen Herodes, el Centurion y los dos soldados.

Cent. En esta ocasión, Señor, quisiera estar dispensado de presentarme ante Vos, porque siempre me he preciado de dar en qualquier asunto cumplimiento a vuestro agrado. De Belén y su comarca venimos ya despachados de hacer las más eficaces diligencias, que importaron para una empresa tan ardua: Mas, Señor, todo fué en vano, porque en negocio tan útil ni un paso se ha adelantado. De quantos medios $y$ ardides inventó el ingenio humano nos valimos; pero todo quanto hizimos, fué escusado. En la Ciudad y arrabales, en los montes y en los campos, en las más ocultas breñas he inquirido, he indagado, y nada hemos adquirido; 
por lo que a vuestro mandato

venimos con el pesar

de no haber el lleno dado

a una empresa, que fiasteis

de solo nuestro cuidado.

Pero bien veis, gran Señor,

1 19] que no ha estado en nuestra mano.

Si en otra disposición

os agrada de emplearnos,

ordenad a vuestro arbitrio,

que prontos a todo estamos.

Mus. Herodes inhumano, porqué temes

Que venga el Alto Dios por Rey Supremo;

No quita no los Reynos de este Mundo, Quien viene a dar los Celestiales Reynos.

Durante la Música está Herodes como confuso y parado.

Hero. Por la experiencia conozco,

Capitanes estimados,

la lealtad con que os portais

en mi servicio, esto es claro.

Las diligencias que hicisteis,

para que desagraviado

quedase mi honor, me constan;

pero el no haberse logrado

la pretensión consabida,

no arguye hubieseis faltado

en la exactitud que pide

practicar un Real mandato,

y más quando el mismo Rcy

os hizo especial encargo.

Supuesto que soys leales

y los más interesados

en volver hoy por mi honor,

que lo mirais agraviado

por un Rapaz atrevido;

soy de parecer, y os mando,

como a mis más confidentes,

como a mis más inmediatos,

que cuideis de reparar

mi propio honor lastimado.

Del modo que habeis de hacerlo

yo os lo diré: ese Muchacho

que se oculta, es mi sangriento

enemigo declarado:

él a escusas me hace guerra,

$e ́$ intenta con desacato

quitar de mi mano el Cetro; 
esto es un fiero atentado,

digno del mayor castigo;

y asi es preciso buscarlo, para darle el merecido

a lo enorme del pecado.

El medio más oportuno

y fácil para encontrarlo, sin que se escape, atended.

Supuesto que es un Muchacho

el traydor que me hace guerra,

y en Belén nació, es muy llano,

que en su Patria entre los suyos

esté ocultó, por lo tanto,

quitando la vita a todos

los que son contemporaneos,

sin perdonar a ninguno,

es fácil que el agraviado

sabiéndolo, lo delate;

y aunque no, muriendo tantos, entre la turba es dificil

que no pague su pecado

con la vida el traydorcillo.

Esto he pensado, y discurro

será lo más acertado. Alto!

a defender a su Rey,

Capitanes, esforzados:

mi enemigo está en campaña,

que es un Rapaz conjurado,

pocas fuerzas bastarán

para dexarlo arruinado:

para convertirlo en nada,

sobrará solo idearlo.

Pasad al punto a Belén

y a sus pueblos comarcanos

con los Verdugos del Reyno,

auxiliando los Soldados;

y a los Infantes que halleis

nacidos desde dos años

hasta un día, sin piedad

al instante degollarlos:

no perdoneis vida alguna,

porque si uno queda salvo,

pensad, que aquel puede ser

el Reo, que vais buscando.

Rendid las vidas a todos,

sin que os cause algun quebranto,

que entre tantos inocentes,

es fuerza pague el culpado. 
No os ablanden los lamentos

de las Madres, no hagais caso

de sus lloros y suspiros:

de la carne desnudaos

y vestios del diamante:

entrad sin algun reparo,

escudriñando las casas,

$y$ con furia arrebatando

quitad vidas sin recelo

que os acusen del pecado,

porque yo que soy el Rey,

os lo encargo, y os lo mando.

La que a su hijo defienda,

importuna, hacedla cargo,

que morirá si resiste

lo infalible del mandato,

y si acaso no se rinde

a la amenaza, en las manos

llevais el acero, al punto

pague tambien su atentado.

Para obviar las detenciones,

ya estais inteligenciados.

Nobles sois, de vos me valgo.

Yo el Rey. Mi honor necesita

que lo deis desagraviado.

Vase.

Mus. De qué sirve tan bárbaro atentado!

Qué importa a Herodes tan atroz delito,

Quando entre tantas muertes inocentes,

Uno se ha de salvar, y ha de ser Christo.

Durante la misica están como confusos y parados.

Cent. Quién oyó tan cruel órden!

Sold. I. Quién tan sangriento mandato!

Sold. 2. Que disposición tan fiera!

Cent. Que empeño tan inhumano!

pero en fin, el Rey lo manda,

y de ello nos hace cargo:

sublime honor y fineza

nos hace en solo llamarnos

sus confidentes y amigos.

A dar al Rey cumplimiento

el más puntual y exacto

de su órden, aunque sea

el más atroz é inhumano.

De Tigre son mis entrañas, en León sangriento y bravo 
me convirtió la lealtad

que debo a mi Soberano. Vise.

Sold. I. Dragón seré que en mis garras

haré pedazos a quantos

Infantes hay en Belén. Vaise.

Sold. 2. Basilisco envenenado

seré con mi propia vista, para dar la muerte a quantos

Infantes se me presenten

en honor del Soberano. Váse.

10

Salen Isaac y Jacod Pastores.

Jac. ¿Conqué en fin, no me dirás

qué tienes, ú qué te ha dao,

pus te veo a toas horas

tan triste y acobardao?

te se ha muerto tu moger?

$\dot{o}$ algun jijo? ú te han quitao

alguna cosa? ú paeces

de mojarrillo, ú empacho?

¿qué tienes, hombre, que estás

20

como carnero amorrao?

desecha ese mal humor

$y$ no estés tan mogigato.

Isac. Yo no sé, amigo Jacobo,

que te iga, en este causo,

pus ni a mi me duele naa,

ni allá mi gente me ha dao

que sentir en cosa alguna,

ni tampoco me han quitao

lo que se monta un dinero,

$y$ con too eso me jallo

$\tan$ asurronao $y$ triste,

que no pueo desechallo,

de tal aquel que ni duelmo

ni me saben los bocaos,

y tengo unas acedias,

que me dan de quando en quando

que me traen casi en un pié

como Grullo.

Jac. Ese es empacho

de haber comío la leche

y encima de ella el gaspacho.

Isac. No es eso lo que me tiene ansí tan desazonao.

Jac. Te habrán jecho mal de jojo ú estarás maleficiao. 
Isac. Lo que tengo en mi presona, yo me lo sé, y me lo callo.

Jac. Pus perdona que te rete: jaces muy mal en callalo, porque los males son menos dempues de comunicaos.

Isac. Dices bien, $y$ he de tomar el consejo que me has dao. Has de saber, guen Amigo, que en estos días pasaos, quando abaxé allá a la Aldea, llegaron unos Armaos jaciendo grandes pesquizas por too aquel vecindario, percurando al Niño Dios, con órden del Soberano para llevarlo consigo: estuvieron indagando tambien con gran deligencia, qué Pastores vesitaron al Niño en aquella noche que nació al mundo: por tanto entrando en cuentas conmigo, y atando acá munchus cabos, he pensao que estas cosas tendrán remate muy malo, $y$ ansi por eso me ves tan triste y desazonao.

Jac. Pus en qué vendrá a parar?

Isac. Es muy astute el pecao. Yo me he pensao que Heroes de la invidia está tocao, porque llegó a su noticia los pruigios que pasaron en el Santo Nacimiento del Niño Dios Soberano, y como de aqui se sigue, haberse el tiempo llegao de reynar en Israel el Masias que esperamos, y él este Reyno lo ticne, como sabes, usurpao; por no verse en el sonrojo de que le quiten el mando, ha dao órden que se busque á Jesús para matallo.

Jac. Por dónde lo sabes tu?

Isac. Acá me lo he barruntao, 
y no es juera de camino, porque Heroes es malvao.

Jac. Y dónde para Jesús?

Isac. Ese es el llance apretao, que en Belén y su comarca, jasta hoy no la han topao, ni se sabe donde esté; pus con muy grande cudiao en toa Jerusalén

y en Nazarén lo han buscao, $y$ no jallan aún su sombra.

Jac. Se habrá en la Groria encajao con sus Payres, sin que al Niño le cueste nengun trabajo. Ojalá que juera ansina $y$ que se hubiera acoldao de llevar tras sí el Portal con los demás agregaos de Pastores, Mula y Guey, que estonces más bien libraos escapábamos nosotros, que Heroes con su Reynao. ¿Y porqué a Jesús no topan, estás ansí amoginao?

antes debía alegrarte no lo encuentren los Armaos.

Isac. Ansí es que eso me alegra;

pero me trae desvelao

$y$ sin gusto el contemplar que este Heroes desalmao jará una acción como suya por havérsele fustrao el jallazgo de Jesús.

Jac. No querrá el Niño Divino mos socéa naa malo, porque juimos los primeros que Humano lo aoramos.

Isac. Yo tambien digo lo mesmo; pero como só casao, siento a mi probe familia.

Jac. Ese es chico pleyto, helmano, que a naide le falta Dios: quando llueve, nos mojamos toos, $y$ el Sol quando nace, alumbra a guenos y a malos Permita Dios de Israél, jalles todo sosegao, y ansí guelvas por acá 
160

más alegre y consolao.

El que tiene ubligaciones,

anda a sombra de tejao;

no hay como estar siempre mozo,

porque dice aquel adagio:

El Guey suelto bien se lame,

que esto de estar uno atao

con la moger, y los jijos,

es un chasque muy pesao;

no quiera Dios que el joicio

Io

pielda yo por ese lao.

Josef deniro dice lo siguiente a voces.

Jos. Alagee! tmirad, Pastores,

que hay un Lobo en el ganao

muy grande que va a matar

los corderillos tempranos.

Jac. Si no me engaña el oido,

Júscpe suena en el plao;

voy a arrancar jácia allá

para ver si es el muchacho.

IIace que vá, y salen al encuentro Jusef y Rebeca.

Jos. Dios sea alabao.

Jac. Por siempre.

Hombre, pue me has asustao;

qué lobo es ése que ices,

si el ganao está pastando

con munchísimo sosiego?

Jos. No es lobo que jace daño

a esos corderos, son otros

Corderos Circuncidaos,

$y$ el lobo es un Rey furioso,

vengativo $y$ desalmao.

Jac. Pus qué hay de nuevo en la Aldea?

Jos. Muchos suspiros y llantos,

porque se suena un run run,

que Herodes apasionao

quiere matar a los Niños,

porque a Jesús no ha topao.

Las Maires lloran que rabian, $y$ del medio van quitando

a sus jijos, yo me vine, por no ver este traspaso, y Rebeca por lo mesmo conmigo se ha refugiao.

Reb. No tengo yo corazón

para sufrir dolor tanto. Llorando. 
Jac. Y por dónde se ha sabío?

Jos. De la Corte lo avisaron con muncho secreto a uno, $y$ al punto se ha publicao.

Jac. Quizá será eso mentira.

Jos. Qué ha de ser! si está raviando como un perro el Rey Heroes por el llance de los Magros, que se jueron a sus tierras, y lo dexaron bulrao, $y$ sin tener parte en esto los de Belén, ha jurao que se la hemos de pagar, y ansí los probes muchachos, sigún han dicho, serán los que pagarán el pato, y sus Payres jontamente, porque al ver este traspaso munchos largarán la piel.

Jac. Que Rey tan desatinao!

Reb. En el mundo no es pusible haya otro tan tirano, tan cruel y tan feroz, tan vengativo $y$ tan malo.

Jos. A bien que allá lo verá con sus amigos los diablos. Y el Rabaán donde está?

Jac. Pus qué no lo habeis topao?

Jos. Echaría por la trocha.

Jac. Jué a la Aldea de un volazo, como anda ese rumor estos dias, y es casao, se jué el probe a ver su gente, muy triste y desconsolao.

Dios quiera que pare en bien esto que se ha levantao.

Vamos al rancho, Rebeca, echarás penas abaxo con un lindo pimentón.

Reb. No pasaré ni un bocao.

Jos. Yo sí, que nunca me enojo con la comía y el trago.

Reb. Tu no sientes ni consientes.

Jos. Eso, Rebeca, es muy falso, porque a la verdá, yo siento quando se me da mal trato en las horas del comer, y aunque este sentir no es jarto, 
jarto siento no estar siempre

con el estbgamo jarto.

Vamos al rancho, Rebeca,

que es lo que nos jace al causo:

los duelos con pan son menos,

en estando lleno el pancho,

mas que mos deguellen luego.

Reb. Bendito el que te ha criao!

Jos. Muera Marta, y muera jarta:

Jacobo, vamos al rancho,

10 que lo emás no es conmigo.

Jac. Rebeca, dexa ese llanto, sígueme, y de las sandeces de Jusepe no hagas caso. Váse.

Reb. El Cielo me dé pacencia con zagal tan insensato. Váse.

Jos. El Cielo me dé que coma, conforme la jambre traigo.

Váse, y deniro suena rutdo de caxas, trompetas roncas, espadas $y$ voces de lamentos, $y$ dice el Centurión lo siguiente.

Cent. No quede ninguno a vida, mueran todos degollados, pues así lo manda el Rey.

Al arma, al arma, Soldados, alístense los verdugos, pasen a cuchillo quantos infantes hay en Belén, y en sus Pueblos comarcanos.

\section{Raquel dentro.}

Raq. Hombre perverso, deténte, cruel y el más inhumano, entrañas de fiera, aparta, no separes de mis brazos a este hijo de mi vida: mátame a mi, y dexa salvo

Verd. I. Muger, a este Inocente.

no resistas al mandato, que morirás tú tambien.

Raq. Muera yo, y este pedazo de mi corazón que viva.

Verd. 2. No hay resistencia a mi brazo.

Raq. Suelta, infame, atroz verdugo.

Cent. Se escapó, cogedle el paso. 
Sale Raquel con el Niño despavorida.

Raq. ¿A donde ire, gran Señor, huyendo de estos tiranos? venid, Salvador del mundo, a qué esperais? presentaos

a los sangrientos verdugos, y viéndoos, estos malvados dejarán nuestros infantes.

126] Sale el Centurión, los dos Soldados y los dos Verdugos.

Cent. Aquí está; llegad, Soldados.

Io

Raquel se arrodilla.

Raq. Quitadme la vida a mí, y dexad mi niño salvo.

Verd. I. También te la quitaremos, si no entregas el muchacho.

Raq. Aunque me quites la vida, aunque me hagas mil pedazos, no entregaré yo a mi hijo. Quién vió tan cruel estrago! quién dió órden tan feroz, tan cruento é inhumano!

Cent. No seas pertinaz, Raquel, obedece el Real mandato.

Raq. Es fiereza y crueldad sugetarse a tan tirano precepto, y en mí no cabe, como madre, el entregaros al hijo de mis entrañas, para que le hagais pedazos. Dadme la muerte primero, execútese el estrago en mi persona, y no vean mis ojos tan desastrado, injusto y cruel castigo en mi niño.

Cent. No cansaros:

obedecer es preciso el órden del Soberano, que es infalible, $y$ así la resistencia es en vano. Entregadle voluntaria, porque si no, violentaros será forzoso.

Raq. No entrego, ya lo he dicho, no me allano a tal fiereza. 
Cent. Escusemos razones, que son en vano;

asidla sin detención, despojadla del muchacho.

Forcejan los Verdugos por quitarle el infanto, $y$ dice Raquel con lamento:

Raq. Ha, infame y atroz verdugo, hombre cruel y malvado! dexa al hijo de mi alma, no me quites un pedazo de mi vida; suelta, aleve, atroz, sangriento, inhumano.

Verd. No hay clemencia.

El Verdugo segundo se lo quita, y váse con él corriendo.

Raq. Hijo mio!

ya sin consuelo he quedado:

qué crueldad tan enorme!

ya sin vida me has dexado.

¿Qué mal te hizo mi niño, iniquo Rey desalmado,

para tan atroz venganza?

voyme tras esos malvados

a rescatar a mi hijo, aunque en menudos pedazos

lo tengan ya dividido.

Vase corriendo, $y$ suena ruido de espadas, caxas y trompetas, $y$ salen el Centurión, Soldados y Verdugos, y sin dexar de marchar dice el Centurion:

Cent. Saquead todas las casas, y no cesad de ir tocando a deguello. Sin clemencia quitad vidas, no hagais caso de respetos, pues el órden expreso del Soberano es, que a nadie se perdone.

Dáos priesa en ir matando.

Vánse con el mismo ruido, y por otro lado sale Raquel con su niño degollado, que será una escullura, y con mucho dolor dirá:

Raq. Hijo de mi corazón, inocente castigadol a donde iré ya sin tí? ya he quedado sin amparo, ya he quedado sin consuelo, 
ya me faltó mi regaló: ¿qué delito has cometido para asi haberte quitado tan atrozmente la vida? $\mathrm{Ha}$ infame, que me has dexado la muger más infeliz que hay en el mundo! ha tirano, entrañas de Basilisco, Rey perverso y obstinado, el Cielo te dé el castigo, qual merece tu atentado.

Váse, y salen Jacob, Josef y Rebeca.

Jac. Qué hay de novedad, Jusepe?

tu vienes muy asustao.

Jos. Qué ha de haber? que esos malditos,

peores que condenaos, Armaos del Rey Heroes, han jecho tan grande estrago en los niños de Belén, y tambien en los muchachos de la Aldea, que es horror, es un dolor y un quebranto. Que dimoños de Sayones! too lo van arrasando, a nengun zagal perdonan de dos años para abaxo: en pasando por aquí diez y nueve, o veinte anos, no se encontrará en Belén ni en sus Puebros comarcanos quien sea Payre, porque agora apuran los muchachos. No he visto Rey mas vinagre, mas perro, ni mas gabacho, su Magestá lo premita, que se lo lleven los diablos.

Reb. Dios mos asista, Jacobo: quien vió causa tan extraño!

Jac. En los añales del mundo no se ha leío más raro.

Jos. Porque esta mañana estaba

a una probe consolando, que la mataron su jijo, por esto me la ha jurao uno de aquellos Sayones, $y$ me ixo el desalmao que se la habia de pagar. 
Tambien los desesperaos se han dexao icir, vendrán por los montes y los campos a degollar los zagales que encuentren desperdigaos.

Centurion dentro.

Cent. Vayan marchando las tropas hasta los montes más altos, divídanse por patrullas, y abancen a los costados, registrando hasta las grutas de los más duros peñascos, por si ocultan algun reo y al instante degollarlo.

Jos. Caracoles con tu alma: Dios me libre de tus manos. Asomase por entro cortinas.

Reb. El Señor mos favorezca y ampare en $\tan$ fiero asalto.

$$
\text { Josef mira al vestuario. }
$$

Jos. Por allá abaxote vienen esos malditos perrazos en quatro ó cinco montones, cada uno por su lao: un pelotón se encamina por la trocha jacia el plao, otra tira a la montaña, $y$ el otro va repechando por la lomilla; ; ay qué susto! que el otro viene guiao jacia acá con muncha priesa! qué pinchos traen en las manos! de esta vez mos descabezan. Ay, que me dá mal de marro! tápame por Dios, Rebeca, no sea que estos gabachos me echen la vista encima, y executen lo jurao.

Todos temblando, y Josef se tapa con el delantar de Rebeca.

Reb. Dios mos defienda y mos libre.

Jos. Estó ansí bien tapao?

Dentro Soldado primero.

Sold. 1. Arma, arma, guerra, guerra, abanzad, fuertes Soldados. 
Jac. Tápame tambien a mí.

Jos. No, que no pueden dos gallos estar en un gallinero.

Jarre allá, alicrujo ganso, que esta moger no es tu helmana.

\section{Lo empuja.}

Jac. Punto en boca, señor gallo.

Reb. No es peleis, que ya llegan,

Dios mos dé too su amparo.

Salen el Soldado primero y los dos Verdugos.

Sold. 1. Muger, aunque más ocultes

lo que venimos buscando,

no te ha de valer: entrega

con sumisión al mandato

de nuestro Rey, los infantes,

que tuvieres de dos años

hasta un día de nacidos,

no te escuses, que es en vano.

Salen Jacob y Josef temblando, é hincan las rodillas.

Jos. No hay mas que los dos, señor,

que somos dos taragallos,

tamaños como dos lomas,

que si nos ponen yuntaos,

aurque no mos pinchoneen,

poemos tirar de un carro:

no mos mate osté por Dios, porque estamos ya surraos de solo ver estos pinchos.

Sold. I. Yo pregunto, sois casados?

Jos. No señor, semos doncellos,

albarranes, celibatos, mozos solteros, y a naide

Sold. I. Y tú, muger?

le jacemos nengun daño.

Reb. Só doncella,

$y$ este zagal es mi helmano.

Jos. Señor, es mayor que yo.

porque me lleva once años, y si no, que enseñe el diente, verá osté que no le engaño.

Sold. t. Este Pastor gasta humor. (Aparte.

No temais, que no intentamos

haceros daño: decidnos

si ocultan esos peñascos

algun infante? 
Jos. Señor,

lo que hay por aquí, son Grajos,

y pegan unos graznios

que mos traen atolondraos.

Sold. 1. Dices mui bien; a la empresa,

seguid el monte trepando,

escudrifnad esas breñas,

obedeciendo el mandato

de nuestro Rey con rigor.

Vánse, y levaintanse los Pastores.

10

Jos. Con doscientos de a caballo

váyanse los mataores

de los niños, que no gano

para sustos con tal gente.

Siempre me traen estos trastos

a dos bombas: arrenuncio

de tan pelvelso ganao:

vámonos a la majaa,

echaremos un guen trago

a la salú de que Dios

mos libre de estos gavachos.

Jac. Por mi para luego es tarde.

Reb. Qué pecho tienes tan ancho.

Jos. Muérase la muerte, yo

solo temo al de lo Alto:

en llegándose mi hora,

al istante lío mi jato,

y sin decir só, ni jarre,

me voy con Dios decontao.

Rebeca, no te amogines,

vamos a echar ese trago

a la salú de los niños, que sin jabrar confesaron

a Jesu-Christo muriendo,

y por esto ya son Santos.

Vánse.

Mus. Volad al Cielo, flores de los Mártires, Al mismo tiempo de nacer cortadas, Por impía mano, como dobla el Cierzo

Las bellas rosas del Abril tempranas.

De Christo sois la Víctima primera,

Y como tierna Grey al pié del Ara,

Con puras manos é inocentes risas

Jugais con las Coronas y las Palmas.

Fin. 


\section{La Perdida de Ntro Señor Jesu-Christo de} doce años.

\section{Coloquio Noveno.}

\section{Personas.}

La Virgen.

San Josef.

Dos Hombres.

Una Muger.

Isaac Rabadán.
Jacob Pastor.

Josef Pastor.

Rebeca Villana.

Música.

10

Mús. Para Gloria de mi Padre, exaltación de mi Nombre, y ganar mi Amor al hombre, pierdo el lado de mi Madre.

Salen Josef y Rebeca.

Jos. Gracias al Cielo, Rebeca, que ya mos hemos topao:

¿has visto bullón más grande que el que ha venío este afoo?

Reb. Sendo que tengo narices, no me acueldo haber estao

mas achuchaa en el Tempro, no habia donde echar un grano de trigo, sigún la gente ha concurrío este año.

Jos. Por poquito esta mañana

131] entre el bullón ajogao me queo, si el Rabaán no me ha sacao de un brazo.

Reb. Siempre en estos siete días 30 de los Azimos sagraos acúe muncha más gente que en las otras jiestas. 
Jos. Vamos,

si te parece, Rebeca,

a la Aldea de un volazo.

Reb. Oyes, Jusepe, otra cosa,

sabes como estuve habrando

con Jesús, María y Josef

ayer yendo al Tempro Santo.

Jos. Y cómo están sus Mercees?

Reb. Tan bellisemos, tan Santos, tan afabres como siempre:

si tu vieras con que agrao

me saludaron los tres

$y$ por ti me preguntaron.

Jos. Si, esta gente es una Groria!

cierto me hubiera alegrao

habellos topao; sende

que tiene el Reyno Arquelao, por tres veces los he visto,

la una jué recienllegaos

de Egito, y las otras dos

antañaso, y ogañaso,

quando juí a Nazarén;

pero lo que me ha parao

es el Niño, qué sabio!

y tendrá unos doce años, poco más ú poco menos,

sende el tiempo que ha pasao

de quando estuve en Belén,

con la andustria de aorallo.

Es preciso que este Niño,

sigún tengo yo pensao,

en llegando a mozonguito,

sea en Cencia consumao.

Si vieras! los otros días

me jizo gracia el muchacho,

estaban él y su Paire

un parejuelo aserrando,

y allegó a la puerta un probe,

al menute como un rayo

soltó la sierra, jué adrento,

y trujo al pobre un peazo

de pan, se lo dió, y tras de esto

su abrazo mu apretao. .

Reb. Tiene mucha cariá

con los probes, es un Santo:

y has reparao, que jojos

tiene Jesús tan salaos?

se mantiene $\tan$ bonito, 
tan precioso, tan gallardo, como quando era choquito.

Jos. Antes tengo yo pensao, que mientras más grande va, es má polío el mochacho.

Reb. No sé como no le han jecho mal de jojo!

Jos. Yo lo estraño.

Ea, camina con brio, porque ya no es muy trempano.

Reb. Antes de irmos, es préciso que los dos mos despiamos de toa la parentela.

Jos. Agora falta ese paso?

Reb. Hombre, si es muy rigular.

Jos. Pus si es rigular, golvamos.

Vänse, y sale la Virgen sola.

Mar. Mi corazón con anhelo desea encontrar ansioso a Josef mi caro Esposo, por ver su mayor consuelo: tal es mi Jesús, mi cielo, mi Niño el más prodigioso. Mas ay de mí! receloso me anuncia un gran desconsuelo; no quiera Dios que tal duelo padezca tan pesaroso. Turbado mi pensamiento duda si vendrá mi Amado de Josef acompañado: si no viene, qué tormento para mi Alma! sin aliento estoy de haberlo pensado: la tardanza en gran cuydado me pone, $y$ el sentimiento va tomando grande aumento, al ver que ya no ha llegado.

Sale San Josef por otro lado sin ver a la Virgen.

S: Jos. Con el Niño mi Maria

salió del Templo Sagrado, se vino por otro lado, porque siempre en tales días desdice la compañía de ambos sexos, yo he juzgado que a este sitio no han llegado, aquí estaré: ¡qué alegría 
ocupará el Alma mía

al ver a Jesús mi Amado!

Con tan gustosa esperanza,

el contento ya rebosa;

ipero qué pena angustiosa

aflige mi confianza!

dudando estoy, ¡qué mudanza,

qué turbación tan penosa

en este instante me acosa!

pues tengo desconfianza

10

si traerá a Jesús mi Esposa.

Mira la Virgen a San Josef.

Mar. Guárdeos el Cielo, Josef, (ap.

mas ay! qué gran desconsuelo!

S. Jos. Esposa y Señora mía; (ap.

Pero qué es lo que estoy viendo?

no en vano mi corazón

me punzaba el sentimiento.

Mar. No en vano ya me anunciaba

mi Alma tan gran tormento.

$Y$ mi Jesús donde está?

donde queda mi consuelo?

S. Jos. Esa pregunta es la mía,

no viendo con Vos al Dueño

de mi Alma, yo pensaba

que salio con Vos del Templo.

Mar. Lo mismo discurrí yo,

y nos hallamos a un tiempo,

que hemos perdido los dos

a todo nuestro consuelo.

Ay, Jesús del alma mía, llora

$i$ a donde estais, que no puedo

vivir si Vos me faltais!

qué es esto, piadosos Cielos!

¿ cómo podré tolerar

lo agudo de este tormento?

quantas penas y aflicciones

causa este amargo destierro

en que estamos, llevaría

con gran placer y contento,

por no sufrir el dolor

penetrante que padezco.

Qué tribulación es ésta,

Josef míol yo fallezco

a impulsos de tal congoja,

si no me asisten los Cielos. 
S. Jos. Esposa mia, el dolor no tiene igual, yo contemplo

fuí la causa de perderse en esta ocasión el Dueño querido de nuestras Almas. O mi Jesús! yo bien veo, que para tan santa empresa, para tan gran ministerio, como el que en vuestra Sagrada Familia estoy exerciendo 10 de Tutor, Cabeza y Padre, no soy digno, ni aún merezco ser esclavo en vuestra Casa: esta ausencia considero la hicisteis porque no os sirvo, ni os atiendo como debo. Perdonadme, Gran Señor, que a vuestra Piedad apelo; no atendais a mí que soy vuestro más inútil, siervo, a vuestra Madre mirad, que traspasada la veo enmedio de tanta pena de un agudo sentimiento, al ver que os hemos perdido: no dexeis la compañia de los dos, que no tenemos otro consuelo en la tierra más que a Vos, y si el perderos fué ocasión mía, os suplico, $y$ rendidamente os ruego, otra vez me perdoneis.

No os tardeis, que el sentimiento ahoga mi corazón, y ya me falta el aliento.

Mar. Yo fuí la causa, Josef, de perderse mi consuelo, el Hijo del Alma mía, pues no cumplo como debo el ministerio de Madre, habiéndome el Alto Cieló colmado de tanta dicha, que por mí no la merezco, escogiéndome, aunque indigna, (joh Soberanos Mysterios!) de entre todas las mugeres. Esta ausencia la ha dispuesto mi Jesús, para que yo, 
mi tibieza conociendo,

le estime más, le agasaje,

le sirva con más esmero.

Bello Jesús de mi vida,

- Hijo mio, yo prometo

hacerlo así en adelante;

no os tardeis: compadeceos

de vuestro Padre Josef,

que con cuidadoso afecto

os solicita el regalo,

os busca amante el sustento

IO

a costa de su trabajo:

no le deis tal desconsuelo:

miradme tambien a mí

traspasada y sin aliento,

llena toda de congojas,

que convatiendo mi pecho

me anegan sus amarguras,

$y$ producen $\tan$ intenso

Dolor, que es insoportable;

me falta ya el sufrimiento

porque las fuerzas desmayan;

que habiéndome Vos faltado,

perdi mi vida, yo muero.

Hacen demostración de llorar los dos, aplicándose un lienzo 25

a los ojos, y salen Isaac y Jacob sin verlos.

Jac. Con el bullicio la porra

por allá se me ha queao.

134] Isac. Si, es un horror el gentio

que acúe a estos Holocaustos,

por poquito yo me ajogo,

y si no saco de un brazo

a Jusepe, a aquestas horas

está el probe sepultao.

Jac. Y a dónde está?

Isac. Qué sé yo?

jarto estoy ya de buscallo

por calles y callejuelas.

Jac. Siempre anda este pelmazo

juera de manaa: oyes!

mas qué no habías reparao?

Mira a los Santos.

Isac. En qué? dílo.

Jac. En una cosa,

que te ha de causar agrao.

No ves al Señor Josefe

y a su Esposa? 
Los sefiala con la mano.

Isac. Están llorando!

qué tendrán? quiero llegar

a ver porqué es este llanto.

Guárdeos el Cielo, Señores,

beso vuestros piés sagraos,

decidme, si lo merezco,

por ver si pueo aliviaros,

qué os aflige, qué os fatiga?

el corazón traspasao

10

tengo de saber quien sois

y veros ansí llorando.

Mar. Hemos perdido a Jesús,

mira tú, si habrá quebranto

igual a éste! contempla,

si tal dolor tan amargo

15

tendrá semejante! pues

perdiendo a mi Dueño amado,

perdí mi bien, mi consuelo,

mi refugio, mi descanso,

20

a! Hijo de mis entrañas,

mi vida, mi ser, mi amparo,

perdí al mismo Dios, qué pena!

Ay, Jesús mio! Ay Regalo!

bien sabes que yo te adoro,

no ignoras quanto te amo:

donde estás, Luz de mis ojos?

a donde te has ocultado?

porqué te ausentas de mí?

porqué me has desamparado?

30

Isac. Compadecío, Señora,

estoy de oirte, el quebranto

no puee tener parejo

en lo que Dios ha criao,

porque es de marca mayor;

pus conociendo tan craro

quién es Jesús, y perdelle,

es pena de gran tamaño.

$\mathrm{Y}$ cómo lo habeis perdío?

S. Jos. Es estilo inveterado,

como sabeis, que en el Templo

a la Fiesta de los Azimos,

los hombres por una puerta

entren a los Holocaustos,

$y$ por otra las mugeres;

tambien sabeis, que es sentado,

tienen arbitrio los Niños

de entrarse al Templo Sagrado 
176

con sus Padres o sus Madres,

sin que puedan estorvarlo.

Esto supuesto, juzgué

que Jesús mi Hijo amado

acompañaba a su Madre;

por lo que entré descuidado

a rendir adoraciones

a Dios en su Templo Santo.

Mi Esposa juzgó lo mismo,

que lo llevaba a mi lado:

10

confiados uno y otro,

procuramos avistarnos,

ya con algunos recelos,

pues el corazón turbado

con el dolor que esperaba,

anunciaba este quebranto.

Luego que nos hemos visto, supimos que los presagios,

que así nos atribulaban

eran ciertos, por lo tanto

20

mi Esposa y yo justamente

nuestra desgracia lloramos,

sentimos este dolor,

y en tan amargo cuidado,

la pena que más aflige

nuestro pecho, es, que ignoramos

dondo está el Dulce Jesús,

nuestro Dueffo venerado.

Si acaso vos lo sabeis,

os pedimos humillados

nos consoleis, porque ya

súmamente fatigados

con tal pesar tan agudo,

no podemos tolerarlo.

Isac. Sefiores, yo me jolgara

porque pudiera aliviaros

de esa pena que teneis,

habello por ai topao,

luego al punto os lo ixera,

mas no lo he visto: y tú acaso

40

lo has encontrao? qué ices?

Jac. Pus si lo hobiera topao,

había de consentir

que se escapara! en los brazos

lo truxera, o en los hombros, como él quixera, ú andando.

Isac. Lo que siento en esta vez, no ser Zajoŕn ó magro, 
que annque al diablo le pesara,

había yo de acestallo.

Mar. Pastores, quedad con Dios.

Los 2. El os guarde muchos años, y quiera que le encontreis, porque quedeis sosegaos.

Mar. Vamos, amado Josef, vamos con todo cuidado por esas calles y plazas, buscando a este Dios Sagrado.

S. Jos. Vamos pues, Divina Esposa, mitigad vuestro quebranto, que Jesús a quien le busca no dexa desconsolado. Vánse.

Isac. Bien sabe Dios que lo siento: una lástima me ha dao de vellos tan aflegíos.

Jac. En llegando los muchachos

a ser grandes, tienen de estas. Quando yo tenia diez años, me perdí un montón de veces, mis Payres desatentaos, por las calles me buscaban, y quando mas descoriaos se jallaban, por las puertas me entraba, pegando saltos, más fresco que una lechuga: lo mesmo tengo pensao jará Jesús Nazareno: quando estén más descoridos, entrará pegando brincos, ú lo jallarán juegando en algun Portal con otros zagales de su tamaño.

Isac. Calla, bárbaro, ¿qué quieres comparar un Niño Santo con los demás? ¿qué no sabes, que éste es el Verbo Encarnao? ¿ parece que no te acueldas de too lo que ha pasao? ¿te se olvió que este Niño jué el que en Belén aoramos, $y$ al que le ofrecieron dones los tres Santos Reyes Magros, y querias que juegara un Nifio tan Soberano? eso es gueno para ti, quando tenías pocos años, 
- para mí y los demás, que tambien yo juí muchacho.

Jac. ¿Y juera algun impusible que el Niño como muchacho, juegara en algun portal con otros de su tamaño?

Isac. No es impusible, mas esto, como que a un Dios Humanao, parece que le repuna, $y$ es indecencia aún pensallo.

Jac. Agora digo que tú no sabes lo que has jabrao.

A Dios lo que le repuna, es solamente el pecao, pero el juego, que es vertú, quando se jace arreglao, esa niego, Rabaan.

Isac. Qué es vertú? esa no paso.

Jac. Tu estás muy al emprencipio, pues no sabes que es sentao entre gentes sabijondas, que es el juego moerao vertú de la tropelía.

Isac. Me doy por atropellao, por vencio y confundio.

Jac. Quando yo jabro un vocablo, sé muy bien lo que me igo. $Y$ mas que no he estodiao, pero sé donde me aprieta la correa del zapato.

Isec. Seffor dotor, no reprico, yo me doy por rematao, y confieso que es osté Teoblogo de Secano.

Jac. Sobre too, Rabaan, ese Niño Soberano dónde nació? en un portal; luego no era mal mirao, que en un portal lo topasen, como los tres lo topamos.

Isac. Digo, pues, señor Jacobo, que es osté ya consumao Rabino, y pudiera estar en el Templo acomoao.

Jos. Dios guarde a ostés, caballeros. Los 2. Hombre, dí, donde has estao? 
Jos. Por calles y callejuelas, buscándoos aperreao.

Isac. A ver, Rebeca, qué moza, y qué cuelpo tan gallardo, metía ya en garambainas.

Reb. Estos son probes jandrajos, que se usan en la Aldea.

Jos. Pero están muy aseaos, porque Rebeca es prulija: la verás con quatro trapos que parece una Seffora.

Reb. No hagais caso de mi helmano, ya conoceis su sandez.

Isac. No, que naa ha ponderao.

Reb. Yo estoy de qualquier moa muy pronta a vuestro mandao.

Los 2. Para jacerno mercé.

Isac. Pero dexando esto a un lao, por las calles que veniis, habeis encontrao acaso por dicha vuestra a Jesús?

Jos. Yo por mi no lo he topao.

Reb. Ayer lo ví, que sus Paires lo llevaban de la mano, por más señas que los tres

a jabrarme se pararon

y preguntaron por éste.

Señala a Josef.

Jos. Me quieren muncho estos Santos.

Isac. Pus hoy saliendo del Tempro, sus Paires quando allegaron a verse, lo echaron menos, se ha perdio, y un quebranto tienen $\tan$ grande que pienso largarán la piel entrambros: es compasión el oillos, $y$ el vellos es un traspaso.

Jos. Yo apostara con qualquiera, que el Niño ha pegao un salto, se ha encajao allá en la Groria, $y$ a toos mos ha ejao de un color: no será muncho, quizás estará ya jarto de los hombres, porque semos a qual más peor, más malo, y no querrá vivir más entre tanto desalmao, 
y sino quando nació,

que naide quixo amparallo:

si mosotros no hemos ío

a llevalle los regalos,

le asiguro a Jesusito,

se havia de haver queao

tocando tabletas: qué!

si esta gente es el pecao.

Son por su naturaleza

los Hebreos muy ingratos,

10

encréulos, vengativos,

y embidiosos como el Diablo.

Ansí no es mucho que el Niño

al Cielo se haya volao,

por no estar entre tal gente.

Isac. Calla, que son tus paisanos.

Jos. Isac, la pasión no quita

el conocimiento craro.

Isac. Pus, companferos, mosotros

estamos muy obligaos

20

a este Niño pruigioso

y a sus Paires tan honraos:

bien sabeis que mos buscó

estando con el Ganao,

llevándonos al Portal,

que éste es un gran agasajo,

pus con nenguno lo jizo

este Infante Soberano

en aquella Noche guena,

y ansina, he determinao,

que en pago de tal mercé

vayamos desperdigaos

por esas calles y plazas

de la Ciá, y por los barrios,

$y$ si juese menester

salirse tambien al campo,

preguntando en toas partes

por este Jesús Sagrao,

dande señas de su Rostro,

de su cuelpo tan gallaldo,

de su Edá, de su Vestío,

veremos si lo encontramos.

Jac. Es muy justo, ansí se jaga,

partámonos a buscallo.

Jos. Y si ansí no se jiciera, juera el pago del capacho.

Por esas calles iré, los jojos desencajaos; 
no me ha de quear portal,

tiendas, puestos, ni tendajos,

balcón ni ventana alguna,

tambien jasta los tejaos

$y$ toas las chimeneas,

que no vaya registrando,

desollinándolas toas

con dambos jojos: por alto

no se ha de pasar nenguna

casa, sin llevar repaso,

10

a ver si jallo a mi Niño.

Manos a la obra, vamos.

Isac. Si hovieras de registrar

too lo que has ensartao,

era menester lo menos

15

que pasara un par de años.

Jos. Como nol por vía mía, aunque me cueste trabajo, aunque se pasen dos Siglos,

he de ir escrudinando

como vendeor de yesca

quantas cosas he mentao:

a la experencia lo exo,

ajila, Rebeca, vamos.

Reb. Las deligencias bien jechas

son guenas en estos causos. Vinse.

Isac. Jacob, tú por esa calle

podrás endilgar los pasos,

yo por esta de la izquierda

caminaré con cudiao:

jacer vivas deligencias

por ver si puedes jallallo.

Jac. Por eso no queará

que echaré el resto en buscallo:

porque el que no busca a Dios,

es un perdío y malvao.

Vánse, y salen por distinto lado la Virgen y San Josef.

Mar. Adónde estais, dulce Dueño!

S. Jos. Adónde estais, Dueño mio!

Mar. Mi Jesús, a quien adoro.

S. Jos. Mi Jesús, por quien yo vivo.

Mar. No hayais de esta pobre Madre que os quiere con amor fino.

S. Jos, No os oculteis de este Siervo que os estima como a Hijo. 
Mira a la Virgen.

Esposa y Señora mía, mi voz no acierta a deciros

lo que ha de aumentar la pena

que padeceis, $y$ el martirio

$\tan$ fuerte que os ocasiona

la ausencia de vuestro Hijo.

Haveis de saber, que ho andado

diversas calles $y$ sitios,

buscando a nuestro Jesús:

10

he preguntado, he inquirido,

entre amigos y parientes,

$y$ en nadie he encontrado alivio,

ninguno me da noticia

de haverlo visto ni oido.

Yo quisiera, gran Señora,

que este encuentro haviese sido

para daros feliz nueva

de nuestro Niño Perdido,

porque cesara el dolor

20

que padeceis tan activo,

y acabara mi congoja;

pero Dios así es servido, conformémonos, Señora, y alabemos sus Designios.

Mar. Mi pena haveis aumentado,

Josef, $y$ haveis añadido

a mi dolor otro nuevo, pues esperando el alivio, se ha redoblado el tormento, $y$ el sinsavor ha crecido. Ay Hijo de mis entraflas! Dulce Jesús, Dueño mio! ¿no bastaba el sentimiento de veros en el peligro

que os puso el difunto Herodes, vano, imbidioso é impio?

¿no bastaba, gran Señor, el trabajo de huir a Egypto, caminando con temores, entre montes escondidos, por desiertos dilatados, con un total desabrigo, sino que quereis ahora sintamos otro martirio mayor que aquel? pues entonces os llevaba yo conmigo, os tenia entre mis brazos, 
$y$ así el dolor tan activo,

lo mitigaba con veros:

mas ahora, Dueño mio,

no os ven mis ojos: pues lloren

la Hermosura que han perdido.

Ambos lloran.

S. Jos. Tened valor, gran Señora, y dadme vaestro permiso, para que yo os acompañe, buscando a Jesús Perdido.

Mar. Venid, Esposo, lleguemos

a preguntar si lo han visto en esta casa.

S. Jos. Lleguemos, que quizá nuestro Divino Protector y Compañero nos conceda algún alivio.

Llaman, y sale al paño un hombre.

Homb. I. Qué solicitais, Señores?

Mar. Si por ventura haveis visto

a un Niño de doce años, que es mi Hijo y se ha perdido?

Jesús se llama, y las set̃as

de su rostro peregrino

son estas: tiene unos ojos

grandes y muy atractivos,

que quando mira, se lleva

los corazones rendidos:

su Nariz es muy perfecta,

de su Boca solo digo

que es limpisima y muy dulce,

sus Labios de coral fino,

sus Dientes lucidas perlas,

su Cabello dividido,

hebras de oro, hermoso y largo:

es su cuerpo tan pulido,

tan gallardo y tan perfecto,

que semejante mi Niño

no tiene en el mundo todo:

es Túnica su vestido,

morado el color: decidme

por quien soys, si lo habeis visto?

porque ya mi corazón

desfallece de afigido,

viendo que no encuentro quién

me dé el más pequeño alivio. 
Homb. I. Compadecido, Señora,

estoy de haveros oido,

quisiera por aliviaros

haver a ese Nino visto:

lo que puedo bacer por Vos,

es buscarle.

Mar. Yo lo estimo:

perdonadlos la molestia.

Ocúltase el hombre.

$Y$ vamos, Esposo mío,

10

a seguir la diligencia.

Oh Jesús! oh Dueño mio!

140] dadnos siquiera el consuelo

de saber quién os ha visto.

S. Jos. Quiero llegar a esta casa,

que en ella vive un amigo.

Mar. Lleguemos por ver si encuentran

término nuestros suspiros.

Llama San Josef, y responde una muger.

S. Jos. Dios sea alabado.

Mug. Quién es?

S. Jos. Señora, por Dios os pido,

escucheis nuestros lamentos.

Sale la muger al panto.

Mug. Qué se os ofrece?

S. Jos. Habeis visto

a un Niño de hermoso talle, que los dos hemos perdido, vestido a lo Nazareno,

con su pelito tendido,

que representa la edad

de doce años cumplidos;

el Rostro muy alagüeño,

sus Ojos muy peregrinos,

su hablar con mucha dulzura

y su mirar atractivo?

Mug. No os canseis en darme señas.

S. Jos. No me canso, antes me alivio

en referir su Beldad.

Mug. Pues, sabed, como ese Niño vivo

llegó a mi puerta ayer tarde

arrecidito de frío;

por Dios me pidió limosna,

se la dí, y agradecido

rog6 al Sefior me colmase 
de gracias y beneficios:

el corazón me partió viéndolo tan peregrino

Mar. Ese $y$ en trage de pobre.

que referiis es mi Hijo, ése es Jesús, mi consuelo, ése es mi Dueño querido, Que alegría envuelta en pena mi corazon ha sentido! (apart.) pues al paso que esta nueva me ha causado tanto alibio, siento saber que mendiga como infeliz $y$ abatido

el Criador y Señor de Cielos, Tierra y Abismos. Dios os lo premie, Señora, y sigamos, Josef mio, que nuestro Dueño piadoso nos prepara compasivo el termino a nuestras penas, $y$ el fin a nuestros suspiros.

Mug. Dios quiera que lo encontreis.

\section{Ocuiltase.}

S. Jos. Pronto estoy siempre a serviros.

Vánse, y sale por otro lado Josef Pastor.

Jos. No sé como no rebiento de pena, que no he podío brujulear donde esté metío este Mamuelico!

o él no quiere que lo topen

o a los Cielos se ha sobío: porque no ha queao calle, rincón, callejuela ó sitio, que haya andao por buscallo, y no encuentro ni aún resquicio.

Voy a llegar a esta casa, que aquí sigún imagino, vive un Oficial Tornero, veré si el buen Zagalico

a la tienda se ha arrimao a comprar, como que es Niño, algún trompo: puee ser. (llama. Dios sea alabao y bendito.

Homb. 2. Por siempre alabado sea: 
qué se ofrece, buen amigo?

Jos. Igame por vía suya, ansi logie ver cumplios tantos años como aquel Matusalén, ha venio aquí a la tienda un Zagal muy regracioso y bonito, como de unos doce aflos,

Homb. 2. Amigo, a comprar un trompo ?

llegan tantos que no es fácil saber de ellos.

Jos. Este Niño, por quien yo pregunto, es tan pintao $y$ tan pulio como un Sol, y a la verdá de una Aurora jué nacío: sus Jojos son de color del Cielo, carmín muy fino sus Labios, o dos claveles de color muy encendio, sus Mexillas leche y sangre, sus Dientes como el armiño, su Pelo tira a castaño, suelto siempre y muy cumplio, su jabrar con manseumbre; es tan humilde este Nifio que es lo mesmo que un Cordero en lo Manso parecíos, por esto lo ando buscando con mas coriao $y$ ajinco no lo pillen y lo maten, porque él no abrirá su pico, lo propio que los corderos, para echar de sí un quexio, ni jará defensa alguna, aunque vea ya el cuchillo: y como el tío Simeón antes de haverse morío, dixo que lo-matarian, estoy con esto aflegio, viendo que ya no parece este mi Zagal perdío:

si acaso lo habrán matao algunos malos Juíos, que de too hay en el mundo! Cómo se llama ese Niño? 
Salvaor y Manuelico,

tambien Jesús Nazareno,

$y$ por apellío Christo.

Homb. 2. Según las señas que dices,

no conozco yo a ese Niño.

Ocuiltase.

Jos. Pus si a Jesús no conoces, eres un perro Juío

o un idiota malvao.

Estoy ya como aburrio

10

con la geringa ú la porra

de no parecer el Niño.

Voy a echar por esta calle:

si encontrara aquí el Choquito, por las que tengo en la cara

le havía de refíi con brío, porque a quatro hombres de bien, mos trae ya sin sentio:

una cosa se me antoja,

que ha de estar el Jesusito

20

en el Hospital, allá

paso entre paso me endilgo. Váse.

Fin. 
La Invención de $\mathbf{N}^{\text {tro }}$ Señor Jesu-Christo en el Templo.

\section{Coloquio Décimo.}

Personas.

Jesús Nifro.

Un Pobre.

La Virgen, su Madre.

Isaac Rabadán.

San Josef. Jacob Pastor.

Quatro Doctores. Josef Pastor.

Un Hombre. Rebeca Vilana.

Un Muger.

Música.

Mús. Bendigan los Querubines

al Nazareno más Sabio, $y$ alaben los Serafines

al más Amante humillado.

Para doctrina y exemplo

de todo el Linage humano

pide limosna el Autor

y Seffor de lo criado.

En Ios Hospitales muestra

20

su caritativo agrado,

asistiendo a los enfermos

el Médico Soberano.

En el Templo manifiesta

con discursos elevados

143]

Mysterios de su Venida

al Mundo el Doctor más Sabio.

Sale Jesuis, que representará un Nino de doce años con tünica morada, ceñido, pelo tendido, báculo en la mano, y con gravedad, modestia y dulzura dira:

Jes. Altísimo Padre mío, venero vuestros Arcanos profundos é inexcrutables: 
obediente a vuestros Santos

Decretos, los he cumplido

sacrificando humillado

mi Voluntad a la vuestra,

aún siguiéndose el quebranto

y angustias que por mi ausencia

padecen mis venerados

Padres Josef y María.

Por siempre sea ensalzado

como en el Cielo, en la Tierra

IO

vuestro Nombre Soberano.

Con qué paternal Amor

$\tan$ fino $y$ tan acendrado

favoreceis a los hombres;

pues por él, determinado

hubisteis que me vistiese

del tosco sayal humano,

con el magnánimo fin

de redimirlos; por tanto

con la mayor sumisión

20

os pido humilde y postrado

por todos, que Generoso

me los habeis entregado:

haced que los pecadores

conozcan vuestro Sagrado

y Augusto Nombre en la tierra,

para que desengafiados

de su infeliz, lamentable

y el más horroroso estado

lo dexen con diligencia

$y$ enteramente mudados

os sirvan fieles y amantes.

Esta petición os hago

como mediador que soy

entre Vos, mi Padre amado,

y entre ellos, vuestros hijos

$y$ mis queridos hermanos:

no desprecieis las hechuras

que formaron vuestras Manos,

por quienes baxé a este Mundo

obediente a vuestro agrado;

aceptad también, Seffor,

los dolores y quebrantos

tan agudos, que en tres dias

con sus noches han pasado

mis Padres, favorecidos

de vuestra liberal Mano.

Nada os pido para Mi, 
porque Generoso y Franco, desde el prodigioso instante de mi Encarnación me has dado absoluta potestad sobre todo lo criado.

Al hombre sí pediré para mejor enseñarlo a que abrace la pobreza y estime en muy alto grado. Bienaventurado sea el que siguiere mis Pasos, Aquí vive un poderoso que al pobre necesitado debe spcorrer, puies Dios le da los bienes sobrados.

\section{Llama.}

Dios sea alabado y bendito.

144] Homb. Quién es? Al paño.

Jes. Carísimo hermano, un Pobre que está a tus puertas, suplicándote humillado, le dés por amor de Dios una limosna.

Homb. Temprano comienza ya el holgazán. Vaya a trabajar, Hermano, que es muy Niño todavía para andarse mendigando.

Jes. Desde que naci a este Mundo no me faltaron trabajos, y los espero aún mayores, que vendrån acompañados de semejantes baldones.

Homb. Para luego es tarde, Hermano.

Jes. No ba de ser hasta que llegue el tiempo ya decretado de mi Pasión y mi Muerte.

Homb. Nada te entiendo: despacio parece estás, pues te matan solamente esos cuidados.

Jes. No estoy despacio, que solo para buscarte he baxado de mi Patria tan veloz, que parecian mis pasos de Gigante, aún siendo Nifio, con tanto placer y agrado, como si en hallarte fuera 
yo propio el interesado;

no cesará mi carrera, hasta que el mismo cuidado

de tu salvación me mate.

Homb. Yo no entiendo de eso, Hermano.

Jes. Yo sí entiendo, que a este fin

soy por mi Padre enviado.

Homb. Pues vaya, que ya me enfada

$y$ me tiene muy cansado:

otra vez, si ha de pedirme.

hágalo más humillado. Váse.

Io

Jes. Me humillaré hasta ponerte

en mis hombros colocado, pues siendo Pastor amante

de mi encargado Rebaño,

lo haré con suma alegría,

quando te haya libertado, qual oveja de las garras

del Lobo infernal, buscando

quién me dé los parabienes

de $\tan$ importante hallazgo:

20

me humillaré hasta morir

en una Cruz enclavado,

porque tú vivas dichoso

entre escogidos y Santos.

Que mal hace quien a un pobre

despide desconsolado,

debiéndole socorrer

de aquello que Dios le ha dado!

Quiero llegar a esta casa

de una muger, confiado

en hallar misericordia:

Dios sea bendito, alabado,

y ensalzado para siempe (llam.

Señora, un necesitado

te pide en Nombre de Dios

le dés siquiera un bocado

de pan, para sustentarse,

porque hoy no lo ha probado.

$$
\text { Al paño. }
$$

Mug. Qué dolor de pobre Niño, tan pulido y agraciado! toma, cielo, yo quisiera este pan que hoy he ganado con afanes $y$ fatigas, dártelo todo, partamos 
como hermanos, hijos todos

de un Padre Dios que lo ha dado.

Lo parte, da la mitad al Nirio, que lo toma y besa.

Jes. La Divina Magestad

te dé el premio que has ganado

en socorrer liberal

al pobre necesitado.

Seas como la Viuda

Sareptana, que en tus vasos

halles el oleo $y$ el pan

siempre abundante y colmado,

porque socorriste afable

con pecho piadoso y franco,

no a Elías que era un Profeta,

sino a mi, que aunque Humanado

soy quien soy, y para tu bien

el más amoroso Hermano.

Mug. Dios me lo conceda.

Jes. Espera

en el Señor, que es muy Grato.

Mug. Quién eres, hermoso Niño?

porque el alma me has robado,

$y$ en tu decir manifiestas

enigmas que yo no alcanzo.

Jos. Soy un Pobre como ves,

Hijo de un Padre muy Sabio,

muy Poderoso y muy Grande,

que por venirme buscando

una Dracma, que perdi,

teniendo allá en mi Palacio

casi infinitas más bellas,

me veo asi desdichado,

infeliz, pobre y mendigo.

Mug. $Y$ por fin la has encontrado?

Jes. Haciendo las diligencias estoy con todo cuidado.

Mug. Pues, Niño, si no la encuentras, retírate a tu Palacio, supuesto que tienes tantas, $y$ todas a tu mandado y no andes de esa manera, como pobre mendigando.

Jos. Esta sola que perdí, la estimo en muy alto grado; por tanto la he de buscar, hasta que cumpla los años Ireinta $y$ tres, $y$ en ese tiempo 
me volveré a mi Palacio.

Mug. Quanto dices, bello Niño, son mysterios que no alcanzo.

Jes. Algun día llegará, que veas mi Padre Amado, y alcances estos Mysterios con entendimiento claro.

Mug. A Dios, Niño, el Cielo quiera halles lo que vas buscando. Váse.

Jes. Qué apreciable es la piedad, pues con muy poco trabajo, por ella se adquiere el Cielo! Pan esta muger me ha dado partido por la mitad; en pago de este agasajo, Pan le dexaré a sus hijos, en que mi Cuerpo Sagrado todo entero comerán, y a ella el Reyno Soberano de los Cielos, porque al Pobre no le ha negado el amparo.

Sale un Pobre clamando sin ver a Jestis.

Pob. Habrá un alma que socorra

a un pobre tan desdichado, que en toda Jerusalén ningún remedio ha encontrado.

146] Jes. Por socorrerte a la Tierra desde la Gloria he baxado, y algún día en esta misma Ciudad verás exaltado (apart. qual Serpiente de Moysés el remedio deseado, que se ha de dar generoso a todo el Linage humano.

El Pobre mira a Jesús.

Pob. Por Dios te pido, Hermanito, me dés siquiera un bocado de ese medio pan que tienes entre tus hermosas manos.

\section{Con gravedad.}

Jes. Alabe primero a Dios, Señor y Autor Soberano, a quien deben las criaturas todo su ser. 
Pob. Alabado

infinitas veces sea

nuestro Dios, que es el amparo

de los pobres, a quien todos

como a Padre le clamamos.

Jes. Antes de pedir al hombre,

debe bendecir postrado

con el corazón a Dios,

su Providencia ensalzando.

Tome ese pan que me dió

la piedad, $y$ ahora humillado

10

por darle exemplo, los piés

le besaré, y este abrazo

reciba de quien enseña

no sólo a amar los hermanos,

sino es a colmar de bienes

a los que causan agravios.

Se posira, le besa los piés y le abrasa.

Pob. Como se conoze, Niño,

la crianza que te han dado!

Bien haya quien a sus hijos

los tiene bien educados.

Dios te lo pague, Hermanito, no sólo porque me has dado el socorro de este pan,

sino porque me has dexado

con tu doctrina $y$ exemplo

reprehendido y enseñado. Váse.

Jes. Esta es la puerta del Templo,

en donde soy adorado

Uno en mi Divina Esencia,

Trino en Personas, por tanto

entraré en mi propia Casa,

disfrazado con lo Humano:

en alla están los Rabinos

con aplicación tratando

de las Santas Profecías, que mi Venida anunciaron, les daré alguna Doctrina, y será Glorificado mi Adorado Eterno Padre. Aquí me vendrán buscando

María y Josef llorosos, y me hallarán disputando, entonces terminarán sus dolores $\tan$ amargos. 
Entrase Jesis por un lado, y descibrese un Templo; on tl I cinco asientos, uno desocupado, y los quatro con los Doctores, que tendrán libros abiertos en las manos.

Doct. I. Tan ardua resolución

pide examen muy prolixo, pues toda la Palestina está puesta en un continuo discurso sobre este asunto, con las señales que han visto

por tanto nos es preciso consultar con todo esmero al Oráculo Divino, para dar satisfacción

al Pueblo, que en divididos dictámenes solicita el saber a punto fixo, si el tiempo de la Venida del Mesías se ha cumplido; y pues ante Dios estamos, pidamos nos dé su auxilio, como a Padre de las luces.

Levántanse.

Dios Altisimo Infinito, en Sabiduría inmenso, amparad a vuestros hijos con los Soberanos Dones de nuestro Santo y Divino Espiritu, iluminando Afable, Pío y Propicio nuestro tardo entendimiento, para dar establecido un punto $\tan$ importante a vuestro Pueblo escogido.

Sientase

Tratemos de la disputa, y sentemos por principio que el Mesías verdadero lo tenemos en el Siglo:

Al decir el antepenillimo verso, entra Jesuis, y se pone en pit 40 detrós de los asientos.

pruébalo con evidencia el haberse ya cumplido a la letra las Sagradas Hebdomadas que predixo 
el gran Profeta Daniel

en su Sacro Vaticinio,

capítulo nueve: ved

si cabe yerro en $\tan$ fixo

y auténtico testimonio,

siendo Oráculo Divino:

esta verdad en sa apoyo

tiene, el verse en nuestro Siglo

a Jerusalén, sin Rey

del Noble y esclarecido

10

Tribu de Judá, señal

de haver al mundo venido

el Mesías que esperamos,

(según Jacob lo predixo)

bendiciendo generoso

a sus carísimos hijos.

Consta del Genesis. Ved

en este Sagrado libro

Abren todos los libros y regisiran.

el Capítulo quarenta

y nueve, hallareis cumplido

este venturoso tiempo,

pues hoy vemos, que el Dominio

de Israel lo señorean

Príncipes advenedizos:

luego es cierto que el Mesías

es a la tierra venido.

Doct. 2. Moysés así lo declara

en su Pentateuco mismo,

y hoy miramos la Judea

señoreada al arbitrio

de. Príncipes estrangeros;

tambien vemos hoy cumplido

el tiempo que prescribió

Daniel para nuestro alivio;

pero aún faltan circunstancias,

que confirmen esto mismo.

Digo asi: el mismo Profeta,

que haveis citado, nos dixo

en el capítulo siete

de su Profético escrito

que a este Señor que esperamos,

como Mesías Divino,

le dió Dios tal potestad,

tal honor y tal dominio,

que de todas las Naciones

del Orbe, remotos Tribus, 
Pueblos y diversas lenguas

le servirán muy rendidos.

Sn Potestad será eterna,

tan entero su Dominio

que jamás le ha de perder,

ni se ha de ver corrompido.

En nuestro tiempo, Senores,

tal novedad no hemos visto,

y un Reynado como este

no había de ser escondido

a nuestra Nación, moviendo

10

los Pueblos más esparcidos

y más remotos del Orbe

a servirle muy rendidos;

luego se infiere de aquí

que el tiempo no se ha cumplido.

Doct. 3. Contra la misma questión

que se ha propuesto, replico:

si el Mesias que esperamos,

estuviese en nuestro Siglo,

20

las Divinas Profecías

se hubieran todas cumplido:

es así que en nuestro tiempo

tal cumplimiento no vimos:

luego el Divino Mesías

todavía no ha venido.

Esta infalible verdad

la prueba el Sagrado libro

de Zacarías Profeta,

el qual de Dios asistido,

al capítulo catorce

literalmente nos dixo:

Abre el libro y lee.

"Vendrá mi Dios y Señor,

„y con él esclarecidos

"todos los Santos, haciendo

"Corte a un Rey tan Peregrino.

Hace que ojea.

Tambien el Profeta Rey,

en prueba de esto nos dixo

al Salmo noventa $y$ seis, que en el Reynado Divino

del Soberano Mesias

se verán grandes prodigios,

señalando su Venida

la alegría y regocijo 
198

que ha de haver sobre la Tierra:

tambien veránse otros signos

de un fuego devorador

a todos sus enemigos:

además de esto los Cielos

conmoverán con activos

volcanes toda la Tierra,

y se verán derretidos

como la cera los montes

más duros y empedernidos.

10

Todos los Pueblos verán

su Gloria, más los Precitos

que adoraron simulacros

falsos, serán confundidos:

para Sión y las hijas

de Judá, Pueblo escogido

será el gozo y la alegría.

En apoyo de esto mismo

el Sabio Rey Salomón, (Ojea

en su Eclesiástico dijo

20

Capítulo diez y seis:

"Que los Cielos, los Abismos

"y la máquina del Orbe

$n$ temblarán estremecidos

$n$ al ver Magestad tan grande.

Estos inmensos prodigios

no hemos visto en nuestros tiempos:

luego tengamos por fixo,

que el Mesiás que esperamos,

aún no es al Mundo venido.

30

Doct. 4. Para más confirmación

de tu argumento, replico

con el capitulo treinta

$$
\text { Ojea y lee }
$$

de Isaias, quien nos dixo:

Vendrá aquel que deseamos

con furor $y$ poderio

de regiones muy remotas,

castigando al que atrevido

insultó su Santo Nombre,

pronunciarán sus Divinos

Labios contra el pecador

el más horrendo castigo,

y su lengua, como el fuego

devorador, al precito

condenará eternamente.

Tambien el mismo nos dixo, 
Ojea $y$ lee.

capítulo treinta $y$ tres, que este Seffor, Juez Divino, vendrá al Mundo como Rey, poniéndonos a su arbitrio

Leyes para la obediencia, y él mismo, Franco y Benigno, nos ha de salvar a todos:

luego, si esto no hemos visto, según los Santos Profetas, el Mesías no ha venido.

Jes. Si vuestro Sabio respeto a quien venero rendido, me concediera licencia para decir lo que he oido sobre el asunto tan grave que tratais, como Rabinos de las Sacras Escrituras, os dierais por convencidos, deponiendo toda duda.

Quedan todos admirados de oirlo.

Doct. 1. Qué Niño tan peregrino!

ᄁ. Extremada es su hermosura!

" 3. Qué decir tiene tan limpio!

7 4. Qué Magestad en el Rostro!

I. Pues dime, Gracioso Niño, serás capaz de exponer el Oracúlo Divino, aún siendo de edad tan corta?

Jes. Sólo diré lo que he oido a mi Padre, que es muy Sabio.

Doct. 1. Siéntate, Bello Prodigio, que atentos te escucharemos.

Sientase en el asiento desocupado.

Jes. Ya os obedezco y prosigo

diciendo como mi Padre

(que siempre acierta) me ha dicho, que el Mesías verdadero, a los hombres prometido por las Sacras Profecias, habia al Mundo venido: esto lo apoya el haberse a la letra ya cumplido las Hebdomadas Sagradas, que el gran Daniel nos predijo, como ya supuesto habeis, 
y el estar hoy el dominio de la Casa de Judá enagenado $y$ habido por Príncipes extrangeros, como Jacob lo previno, proféticamente hablando, allá en los primeros Siglos. Vosotros os confundiis aplicando discursivos a esta primera Venida los Sagrados Vaticinios, que tratan de la segunda. Bien sabeis como Rabinos, que este Señor Soberano descenderá del Empireo dos veces: en la primera vendrá Redentor benigno, y en la segunda, Severo Juez de muertos y de vivos. De esta segunda Venida son los Sagrados Escritos, que habeis citado hasta aqui. Ahora diré lo que he oido acerca de la primera, que muchas veces leido habreis en el Sacro Texto.

Primeramente nos dixo el gran Profeta Isaías en su misterioso libro al capítulo sesenta y dos: que este Dios benigno viene a salvar a Sion, esparciendo beneficios y mercedes a los hombres: así, pues, favorecidos, los llamarán Pueblo Santo, por él mismo redimidos. Tambien al cincuenta $y$ tres este Profeta nos dixo que morirá el Salvador a impulsos de su Amor fino, para hacer la Redención, llevándolo al sacrificio, tan manso como una oveja, $\sin$ despegar vengativo contra el verdugo sus labios: Tambien confirma esto mismo el Profeta Rey David, 
el qual nos dixo advertido en el Salmo veinte $y$ uno, que este Redentor Divino, se anonadó de tal suerte, que dixo de sí abatido:

No soy Hombre, si Gusano, y el oprobrio conocido de la Plebe, despreciado, pues todos quantos me han visto, se mofaron y burlaron: esto alude a su martirio, que le espera en la primera Venida, en la que Benigno Salvador se ha de mostrar, Manşo, Humilde y Abatido, como lo anunció el Profeta Zacarías, quando dixo en su capítulo nueve: que este Señor Rey Divino, Justo y Salvador afable, triunfando de los altivos y vanos Reynos del mundo, de un pobre tren prevenido, entraría en su Sión con el raro distintivo pasmo de la Mansedumbre, de venir a ella subido sobre una humilde jumenta y un jumentillo su hijo. Esto supuesto, entended, que aunque no se hayan cumplido las citadas Profecías, que atentos me habeis oido, no arguye que este Señor aủn no haya al Mundo venido, pues estar ya (como está) sobre la tierra nacido: y debeis saber, Sez̃ores, que lo teneis en el Siglo en que viene generoso, suave, plo y propicio a redimir a los hombres de Lucifér y los vicios.

Doct. 1. Las Profecías que citas, discreto y gracioso Niño, son evidentes, no hay duda; me confieso convencido, concediéndote, publican, 
que el Mesias peregrino

vendrá la primera vez

Piadoso, Amante y Benigno,

a redimir los mortales:

que ha de morir abatido,

a impulsos de padecer

el más sangriento martirio,

y que ha de entrar en Sión

sin aparato magnífico:

todo es cierto y lo concedo:

mas que el tiempo se ha cumplido

10

de mercedes $\tan$ copiosas,

de favores tan divinos,

no lo afirmo, pues no veo

señal alguna, ni indicio

evidente, que demuestre

tal maravilla y prodigio.

$Y$ si no, ¿qué conmoción

de las gentes hemos visto

haya habido en nuestros tiempos,

según Ageo lo dixo

al capítulo segundo

de su Profético Libro,

para afirmar que ya el tiempo

a la letra se ha cumplido?

dínos, Niño, lo que sepas

sobre este asunto.

Jes. Yo digo

lo que a mis amados Padres

distintas veces he oido,

y sucedió en vuestro tiempo.

No os acordais de un Edicto

de Octaviano Augusto Cesar,

que habrá doce años vino,

en que mandaba alistarse

a todo el Orbe, motivo

por el qual todas las gentes

de varias Naciones, Tribus,

se conmovieron a un tiempo

a obedecer compelidos

de $\tan$ superior mandato,

transitando divididos

por la tierra y por las mares,

cada qual a aquel destino

propio de su nacimiento?

¿Tambien a este tiempo mismo,

no os acordais, que una Estrella,

por soberano prodigio 
condujo a Belén tres Reyes

del Oriente, prevenidos

de ricos Dones, Presentes, que hicieron al Rey nacido, cuyas Reales Magestades

se presentaron invictos

en zelo, constancia y fe

ante Herodes, sin motivo

de temor ni sobresalto,

publicando a un tiempo mismo

10

todos tres el Nacimiento

del Mesias prometido?

como antes en el Salmo

setenta y uno lo dixo

el Profeta Rey David:

tambien anunció esto mismo

Isaias al setenta,

manifestando expresivo

en tan Regia Adoración

lo expléndido y exquisito

20

de los Dones, que ofrendaron

al Soberano Dios Nino.

Ved ahora si dudais,

esté ya el tiempo cumplido

de tener entre vosotros

al Mesias prometido.

Doct. 2. Quanto dices es muy cierto,

de todo fui yo testigo;

pero no me negarás,

gracioso y discreto Niño,

que en el grande Nacimiento

de ese Mesías Divino

ha de haber una señal,

que será el más cierto indicio

de su Venida en la Tierra,

según Isaías dixo

en el capítulo nueve,

la que ninguno hemos visto:

dice, pues, de esta manera.

Abre el libro, ojea y lee.

${ }_{n}$ Aquel Pueblo sumergido

nen tinieblas caminando,

"ha visto para su alivio

"la Iuz grande que desea,

ny a los Pueblos afligidos

"que habitan en la Región

"de la muerte, desvalidos, 
„les amaneció aquel día

"deseado y aplaudjdo.

Y en el Versículo sexto

de este capítulo mismo,

dice con toda expresión:

„A nosotros ha nacido

nel Infante pequeñuelo;

nse nos ha dado por hijo,

"quien tendrá sobre sus hombros

nel Principado y Dominio,

"y se llamará Admirable

"Consejero (qué prodigio!),

"Dios el Fuerte (qué grandeza!),

"Padre del Futuro Siglo,

"Principe excelso de Paz,

$n y$ su Imperio el más invicto

"ha de ser multiplicado

"por los siglos de los siglos:

"Sobre el Solio de David

"y sobre su Reyno' mismo

20

nse sentará este Señor,

"para juzgarlo y regirlo.

Cierra el libro.

Esta infalible señal,

esta Luz, este Prodigio,

que ha de ilustrar nuestro Pueblo,

en el Nacimiento inismo

de este Infante Soberano,

no hemos visto, ni se ha oido

tal novedad en Judea:

y si ese Rey ya es nacido,

$y$ ha de ser tan excelente

su Potestad y Dominio,

¿ cómo el Imperio Romano

aún nos gobierna a su arbitrio?

luego se infiere de aquí,

que aunque es cierto, Sabio Niño,

lo que con tanto donaire

y gravedad haveis dicho,

el Mesías que esperamos

aún no es al Mundo venido:

40

Si otra noticia nos das,

te oiremos muy complacidos.

Jes. Digo por obedeceros

lo que mis Padres han dicho

sobre este punto. Advertid

que el Infante prometido 
por Isaias Profeta

es de quien he referido,

nació doce años hace,

$y$ en su Nacimiento mismo

en la Ciudad de Belén

se observó como Prodigio

al punto de media noche

un resplandor excesivo,

una extraordinaria luz,

según David lo predixo

10

en el Salmo ciento treinta

y ocho, en que nos previno:

${ }_{n} \mathrm{Se}$ volvería la Noche

como el día más lucido.

Esta Luz se dejó ver

de unos Pastores vecinos

de Belén, que custodiaban

su Rebaño, y estos mismos

vieron una multitud

de Angeles muy peregrinos,

20

que celebraban las glorias

de este Rey recién-nacido,

cantándole en alabanzas

este Misterioso Himno:

Gloria in Altissimis Deo

$\&$ in terra pax hominibus.

Tambien oyeron atentos

a uno de estos Paraninfos,

que con voces perceptibles

y rostro afable les dijo:

"Yo os anuncio un grande gozo,

nporque hoy os ha nacido

"el Salvador de este Mundo,

"Piadoso, Humano y Benigno

"en la Ciudad de David:

„la señal de este Prodigio

„es que hallareis a un Infante,

"de unos pañales vestido,

"reclinado en un pesebre."

Con tal celestial aviso

partieron para Belén,

y hallaron lo que les dixo

el Divino Embaxador,

y le adoraron rendidos,

confesándole por Dios

y Mesías prometido.

Que este prodigioso Infante

sea el mismo que predixo 
el gran Profeta Isaías,

es forzoso el inferirlo,

miradas las circunstancias

del Nacimiento lucido,

aplaudido y señalado,

como ya os he referido,

y os dignasteis escucharme;

no pongais ahora en olvido

lo que supusisteis antes:

de verse hoy ya cumplido

10

lo que Daniel anunció,

y mirarse sin Dominio

la Casa Real de Judá.

Tambien Miqueas nos dixo

del lugar del Nacimiento

en su capitulo quinto.

¡Tú, Belén, serás la Patria

„donde nacerá el Caudillo,

„que dominará a Israel

„por los siglos de los siglos.

20

Doct. 3. Quanto has dicho, es convincente;

pero si huviese nacido

en Belén el gran Mesías,

ya lo hubiéramos sabido,

que un Nacimiento tan grande,

es impropio é indebido

quedar oculto a Israel,

siendo su Pueblo escogido.

Digo más, si fuera cierto

ser este Infante nacido

doce años ha en Belén,

huviera al Templo venido

a presentarse ante Dios,

según Malaquías dixo

al Capítulo tercero

de su Profético escrito:

que se haya hecho presente,

lo ignoramos: luego es fixo

y constante que el Mesias

sin embargo de lo dicho,

no tiene los doce años,

ni es a la tierra venido.

Jes. Pues yo sé que a los quarenta

días que cumplió Nacido,

su Madre lo traxo al Templo,

y Simeón lo bendixo, aclamando su Grandeza, diciendo, que era el Divino 
Mesías profetizadö

en los anteriores Siglos.

Doct. 4. No hay duda en lo que nos dice este Prodigioso Niño, que a Simeón se lo of antes de haver fallecido; pero yo me persuado que ya ese Infante no es vivo, pues poco tiempo despues se siguió el cruel castigo

de Herodes en los muchachos de Belén, $y$ así es preciso que entre ellos pereciese, por tener alli su asilo.

Jes. Esa misma crueldad confirma todo mi dicho de ser cierta la Venida del Mesías Peregrino, pues Herodes al saber que era a la tierra venido, temeroso de perder su Reynado y su Dominio, mandó atroz tan cruel estrago, $\tan$ feroz infanticidio en Belén y sus contornos, con en infernal designio de que muriera entre ellos este Infante esclarecido, mas no pudo el embidioso Rey tirano conseguirlo, pues la Sacra Omnipotencia le libró de aquel peligro, como antes se escrivió en el Exodo Divino, Capitulo veinte $\mathrm{y}$ tres: "No cocerás el cabrito "en la leche de su Madre, porque el Sabio é Infinito Señor Dios, en sus Arcanos y Secretos 'escondidos, reserva para despues tan inhumano martirio, según cité en Isaías y en David; conque es muy fijo, que el Soberano Mesías no pereció en el impío cruel estrago de Herodes; está entre vosotros vivo, 
llenándoos de mercedes, repartiéndoos beneficios, favoreciéndoos, colmándoos

de su gracia y sus auxilios, alumbrándoos con su luz, dándoos dones exquisitos, amándoos como a hermanos con un amor excesivo: él os ha de redimir del más atroz enemigo, a impulsos de su fineza, con tal muerte, tal martirio tan cruel, $\tan$ inhumano, tan sangriento $y \tan$ impio, que la humana ingratitud, no lo ha inventado en los siglos.

Doct. 1. Quanto dices es un pasmo, un asombro $y$ un prodigio. Atónito y admirado estoy ya de haverte oido, y lo que me tiene absorto, es el mirarte tan Niño, y oirte $\tan$ consumado, $\tan$ capaz, $\tan$ entendido en las Sacras Escrituras. Adonde, dí, ó gran Prodigio, has estudiado? confieso, que me doy por convencido. Nuestras dudas se resuelvañ, que el Mesias ya ha venido. Dos Venidas a la Tierra ha de hacer el Rey Divino, según dicen los Profetas, y nos advierte este Ninó. La primera ya llegó, en que viene a redimirnos como a sus hijos que somos, y su Israel escogido: yo así lo juzgo y discurso, $y$ lo tengo por muy fixo, con solo oir las razones tan sólidas de este Niño, y sus citas a la letra del Sacro Texto Divino; confieso que me ha enseñado, de su Doctrina he salido instruido. Yo quisiera te quedases por Rabino 
del Templo para enseffar

aún a los mismos Rabinos.

Los 3. Pasmosa Sabiduria!

\section{Salen la Virgen y San Josef.}

Mar. Hijo amado!

S. Jos. Jesús mío!

Mar. Perdida Prenda de mi alma!

ya cesó el quebranto mío,

pues que ya vieron mis ojos

a quien es todo su alivio.

10

Ay Jesús, ay vida mía!

¿ porqué así nos has tenido,

a vuestro Padre y a mí, en tal pena y tal conflicto,

como en vuestra ausencia a un tiempo los dos hemos padecido?

S. Jos. El dolor no tuvo igual

que sintió el corazón mío,

al llegar a conocer

haberos, mi Bien, perdido.

20

Doct. 1. Decidme, buena Muger,

este Niño es vuestro Hijo?

Mar. Sí, señor.

Doct. I. Pues estimadle,

que es un asombro $y$ prodigio

en exponer las Sagradas

Escrituras: instruidos

nos dexa con su Doctrina,

absortos y confundidos

quedamos de sus preguntas

y respuestas : dirigidlo

para que sea en el Templo

de nuestro Dios su Rabino.

Doct. z. Extraordinario saber

en $\tan$ corta edad! servios

de concurrir otra vez

a enseñarnos -é instruirnos.

Doct. 3. Dichosos podeis llamaros,

nobles Padres, con tal Hijo:

que no dexe la Sagrada

156]

Lección, que será este Niño

embeleso de las Ciencias,

pues le ha adornado el Divino

Poder de un entendimiento

muy perspicaz y muy limpio. 
Todos se levantan.

$\mathbf{I}$

Doct. 4. A Dios, Niño, que me llevas, cautivo el afecto mio, por tu ciencia sin igual.

El Mundo te aclama invicto!

tus poderosas razones

nos dexaron convencidos.

Doct. I. El Cielo os guarde, Señores,

a Dios, prodigioso Niño.

Vánse y se quedan fuera Jesuis, Maria y Josef. 10

Mar. El mismo Señor os colme

de gracias y beneficios.

Hijo mio, dulce Dueño, ¡qué excelente $y$ exquisito

gozo tiene ya mi alma

de mirarte, ó Amor mío!

¿ porqué, dí, ó Jesús, hiciste

esta ausencia, que ha tenido

a tus Padres que te adoran,

en tal dolor y conflicto?

¿ porqué, Hijo, nos dexaste

al impulso de un martyrio

$\tan$ atroz, $\tan$ insufrible,

como lo es haber perdido

tan peregrina Presencia?

y procurando el alivio

por toda Jerusalén

en Deudos y Conocidos,

no encontraba nuestro anhelo

el más pequeño motivo

de mitigar nuestra pena,

antes crecía el martirio

al ver que nadie nos daba

noticia de haberte visto.

Jes. Pues, para qué me buscabeis?

no sabeis que me es debido

el atender a las cosas

de mi Padre. Yo he cumplido

su Divina Voluntad

en semejante exercicio.

S. Jos. Hijo mío, dad licencia

para que os pida rendido

me admitais por vuestro siervo,

y si fué descuido mío

vuestra ausencia, perdonadme,

que sois Piadoso y Benigno,

que os ofrezco en adelante 
obsequiaros y serviros

con todas las facultades,

que da de sí mi alvedrío:

y ahora, si permitiis.

Dulce Jesús, Dueño mío,

vámonos, descansareis

algún tanto del prolixo

afán que os habrá causado

la indigencia $y$ desabrigo,

mientras dispongo el viage

Jes. No, Padre, que mis delicias

mayores son quando asisto

con los hijos de los hombres,

aunque me vea abatido,

mendigo y necesitado,

no por eso me fatigo,

más alegre estoy entonces,

más gozoso y complacido,

pues la compañía de ellos

la aprecio mucho y me digno,

que mi Padre Celestial

me enviase a redimirlos.

Vamos ahora donde mandes, que a obedecer soy venido.

Lo loma $S$. Josef de la mano.

157] Mar. O Josef, qué dicha teneis de llevar a Dios asido!

A quantos Justos ha habido sobre la tierra excedeis, pués sólo vos mereceis que la Magestad Divina, Soberana y Peregrina sujeta esté $\mathrm{y}$ obediente a vos, de que es consiguiente, domineis al que domina.

Sale Josef muy triste, sin verlos.

Jos. ¿ ¿Donde estará el guen Zagal, que no he podio topallo, por más gueltas y regueltas que por too el Puebro he dao? no me ha queao rincón que no haya mío a pasos, las cárceles, hespitales $y$ el Tempro, too lo he andao, $y$ no lo encuentro: qué pena! 
siento tanto el no jallallo que las ganas de comer parece las he juegao, y las peldí, pues no pueo atravesar ni un bocao, sigún me trae esta desgracia tan triste $y$ desazonao: quiero otra vez ir al Tempro para ver si está en el Atrio.

Hace que se va y repara en el Niño.

Mas qué es esto? ya está aquí,

a ver el remolonazo!

ya pareció Mamuelico,

el Niño peldío: vamos, bello Jesús de mi alma,

dáme un abrazo volando.

Lo abrazo.

Qué allegria, qué contento tengo de habello topaol

Tío Jusepe a la salú de tan superior hallazgo; déme osté sin detenerse otro abrazo mu apretao.

\section{Lo abraza.}

Sea en hora guena, Señora, ya tendrá osté desanchao ese corazón, me juelgo tenga un gozo tan colmao.

$$
A \text { Jestis. }
$$

Otra vez, Señor Jesús, no me sea adelantao; quando vea muncha gente, agarre bien agarrao a su Payre por la capa, que no estamos para chascos toos los días, y ansina coriao con el encargo.

Jes. Yo te agradezco, Pastor, el solícito cuidado en buscarme: en adelante hasta morir, muy exacto lo has de practicar, porque si me pierdes, el pecado te hallará y con él la muerte: no me olvides. 
Jos. Yo, olviaros?

siguro, porque te quiero

más que a mi vía, te amo

sobre toitas las cosas

que hay en este mundo malo,

$y$ si en algo te ofendi,

te pío a tus piés postrao

Se posira.

que perdones mis defeutos, porque como so de barro, es fácil jacerme tiestos

10

Se levanta.

158]

Lo que siento, que el tío Isacio

y Jacob con mi Rebeca

no hayan venio: a buscallos

me voy en una carrera,

porque tengan el gustaso

de ver el Niño peldío

que ya es el Niño jallao;

pero ya no es menester,

que toos tres como un rayo,

20

ansina que mos golieron

se vienen traspagilando.

Salen los tres.

Isac. Jesús, qué placer tan grande! llegad, vereis nuestro amparo.

Jac. y Reb. Señor, el alma se alegra de haberos por fin jallao.

\section{A la Virgen.}

Reb. Señora, mil parabienes de tanto gozo te damos.

\section{A San Josef.}

Jac. Y a vos, dichoso Josef, todos quatro acompañamos en la alegría y contento, $y$ os damos regucijaos quatro mil enhoraguenas por tan importante hallazgo.

Jos. Y dempues de esto el Poeta suplica humilde y postrao le perdonen los defeutos, que en su obra hayan notao los coriosos, y da fin al Poema, celebrando: 
Tod. La Infancia de Jesu-Christo, nuestro Amante Soberano.

\section{Vainse.}

Mús. A Jesús sin cesar alabemos Con cánticos dulces é hymnos acordes, Alabemos su Gloria en lo alto,

La Paz en la tierra a favor de los hombres.

Fin. 